\title{
Geohydrology of Stratified Drift and Streamflow in the Deerfield River Basin, Northwestern Massachusetts
}

By PAUL J. FRIESZ

U.S. Geological Survey

Water-Resources Investigations Report 96-4115

Prepared in cooperation with the

MASSACHUSETTS DEPARTMENT OF ENVIRONMENTAL MANAGEMENT,

DIVISION OF RESOURCE CONSERVATION

OFFICE OF WATER RESOURCES

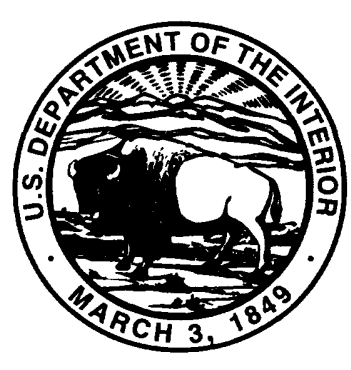

Marlborough, Massachusetts 


\title{
U.S. DEPARTMENT OF THE INTERIOR BRUCE BABBITT, Secretary
}

\author{
U.S. GEOLOGICAL SURVEY \\ Gordon P. Eaton, Director
}

For additional information write to:

Copies of this report can be purchased from:

Chief, Massachusetts-Rhode Island District

U.S. Geological Survey

U.S. Geological Survey

Water Resources Division

Branch of Information Services

Box 25286

28 Lord Road, Suite 280

Denver, CO 80225-0286

Marlborough, MA 01752 


\section{CONTENTS}

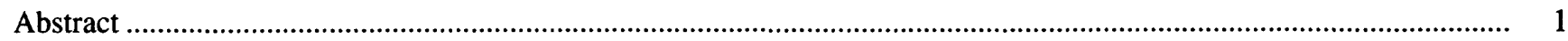

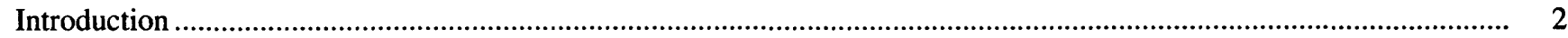

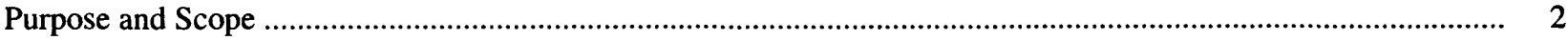

Previous Investigations …………………………………………………………………………………... 4

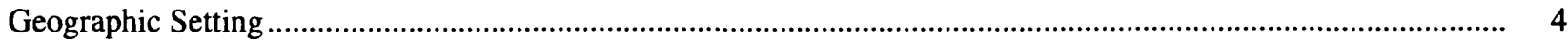

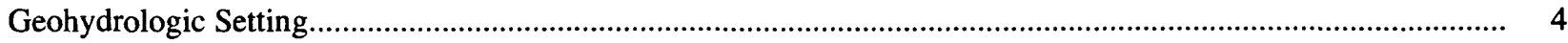

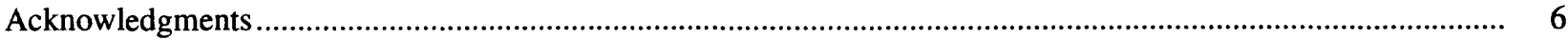

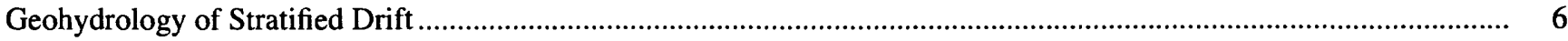

Areal Extent, Thickness, and Lithology of Stratified Drift in the Connecticut Valley Lowlands............................. 6

Hydraulic Properties of Stratified Drift at a Site Adjacent to the Deerfield River.................................................. $\quad 8$

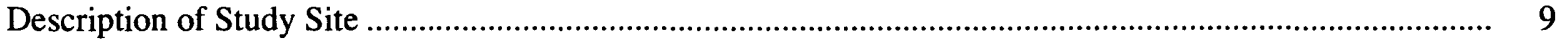

Hydraulic Properties Determined from Simulation of Ground-Water and Surface-Water Interactions ........... $\quad 9$

Description of Model ………………………………………………………………………….... 12

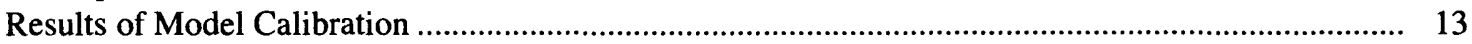

Recharge to a Stratified-Drift Valley Bordered by Upland Till and Bedrock in the Berkshire Hills......................... $\quad 17$

Description of Recharge Study Area ......................................................................................................... 17

Sources and Water Available for Recharge .......................................................................................... $\quad 17$

Seasonal Changes in Ground-Water Levels and Flow Directions ............................................................. 23

Recharge Determined from Simulation of Ground-Water Flow .................................................................. 25

Description of Model ……………………………………………………………………………... 25

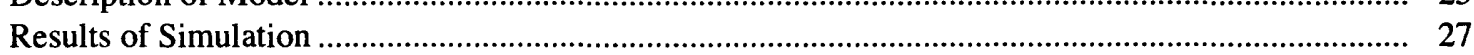

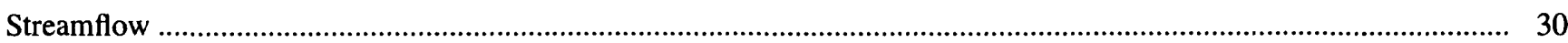

Comparison Between Streamflow in the Deerfield River and Selected Tributaries ................................................ 30

Streamflow at Times of Low Flow ................................................................................................................ 33

Streamflow at Gaging Stations and Partial-Record Stations ................................................................... 33

Streamflow from Stratified-Drift Valleys ............................................................................................... 36

Comparison of Streamflows Per Unit of Drainage Area ............................................................................ 38

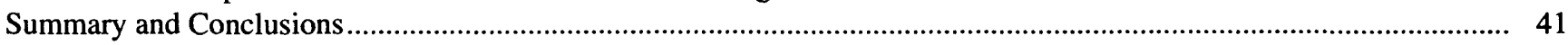

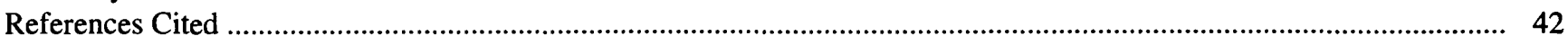

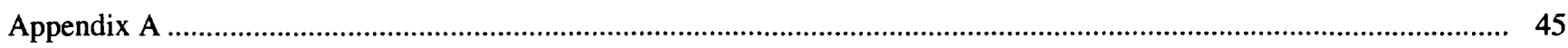

Figure A1. Geohydrologic sections based on seismic-refraction surveys, Deerfield River Basin, northwestern Massachusetts..................................................................................................... 47

Figure A2. Geohydrologic sections based on a seismic-reflection survey, Deerfield River Basin, northwestern Massachusetts......................................................................................................... 48

\section{PLATE}

[Plate is in pocket]

1. Map showing thickness of stratified drift, estimated areal extent of buried coarse-grained deposits, and location of data, Deerfield River Basin, northwestern Massachusetts. 


\section{FIGURES}

1. Map showing location and physical setting of the Deerfield River Basin, areal extent of stratified drift and till and bedrock, and location of study sites used to determine hydraulic properties adjacent to the Deerfield River (study site A) and recharge to a stratified-drift valley (study site B), northwestern Massachusetts.

2. Profile showing altitude of the Deerfield River and locations of hydroelectric developments, streamflowgaging stations, and major tributaries, northwestern Massachusetts.

3. Seismic-reflection record, record interpretation, and a lithologic log from well DFW96 Deerfield River Basin, northwestern Massachusetts

4. Map showing location of observation well cluster sites and section lines adjacent to the Deerfield River, northwestern Massachusetts.

5. Geohydrologic section perpendicular to the Deerfield River showing lithology, well locations, and model layers, northwestern Massachusetts

6. Hydrograph showing changes in stage of the Deerfield River, northwestern Massachusetts, July 5-7, 1994.

7. Hydrographs showing measured and simulated heads for riverbank and far cluster sites, Deerfield River Basin, northwestern Massachusetts, July 5-7, 1994.

8. Map showing location of recharge study area and principal geographic features and data-collection network, Deerfield River Basin, northwestern Massachusetts

9. Geohydrologic section of recharge study area, Deerfield River Basin, northwestern Massachusetts

10. Hydrograph showing ground-water levels in selected observation wells and discharge at Wilder Brook gaging station, Deerfield River Basin, northwestern Massachusetts, October 1993 to December 1994.

11. Graph showing stream infiltration along Wilder Brook, Deerfield River Basin, northwestern Massachusetts....

12,13. Maps showing:

12. Altitude and configuration of the water table for April 14, July 6, August 17, and September 23, 1994,

Deerfield River Basin, northwestern Massachusetts

13. Grid and cell types for the finite-difference model of the ground-water system, Deerfield River

Basin, northwestern Massachusetts.

14. Hydrograph showing comparison of measured heads in observation well B3W29 versus simulated heads using all water available for recharge, all water available for recharge except for March (10 percent less) and April (60 percent less), and all water available for recharge and drains, Deerfield River Basin, northwestern Massachusetts, October 1993 to December 1994.

15,16. Maps showing:

15. Altitude and configuration of the simulated water table using all water available for recharge except March 1994 (10 percent less) and April 1994 (60 percent less) for April and September, 1994 and all water available for recharge using drains for April 1994, Deerfield River Basin, northwestern Massachusetts.....

16. Locations of continuous streamflow-gaging stations, partial-record stations, and stratified-drift

valleys, Deerfield River Basin, northwestern Massachusetts and Vermont ....

17. Flow-duration curves based on daily mean discharges and instantaneous discharges at six streamflow-gaging stations in the Deerfield River Basin, northwestern Massachusetts, water years 1992-94

18. Graph showing streamflow per square mile equaled or exceeded 80,90 , and 99 percent of the time in relation to percentage of basin underlain by stratified drift in the Deerfield River Basin, northwestern Massachusetts and Vermont, climatic years 1968-93.

\section{TABLES}

1. Effects of varying hydraulic properties on the calibrated heads during the rise of river stage, Deerfield River Basin, northwestern Massachusetts, July 5, 1994

2. Water-balance computation of water available for direct infiltration, Deerfield River Basin, northwestern Massachusetts. 
3. Water available from streamflow loss from Wilder Brook and for ground-water and surface-water runoff from uplands, Deerfield River Basin, northwestern Massachusetts

4. Description of streamflow-gaging stations, Deerfield River Basin, northwestern Massachusetts ......................... 30

5. Description of partial-record stations, Deerfield River Basin, northwestern Massachusetts and Vermont

6. Summary of the method of analysis, streamflow-gaging station(s), and the number of measurements used to calculate streamflows and the root mean square error of estimate for each partial-record station,

Deerfield River Basin, northwestern Massachusetts and Vermont, climatic years 1968-93 .....

7. Streamflow at selected durations for streamflow-gaging stations and partial-record stations on unregulated tributaries, Deerfield River Basin, northwestern Massachusetts and Vermont, climatic years $1968-93$

8. Description of stratified-drift valleys, Deerfield River Basin, northwestern Massachusetts

9. Streamflow at selected durations for stratified-drift valleys on unregulated tributaries, Deerfield River Basin, northwestern Massachusetts, climatic years 1968-93.

10. Streamflow per square mile at selected durations for streamflow-gaging stations, partial-record stations, and stratified-drift valleys on unregulated tributaries, Deerfield River Basin, northwestern Massachusetts and Vermont, climatic years 1968-93

\section{CONVERSION FACTORS AND VERTICAL DATUM}

\section{CONVERSION FACTORS}

\begin{tabular}{rll}
\hline Multiply & By & To Obtain \\
\hline cubic foot $\left(\mathrm{ft}^{3}\right)$ & 0.02832 & cubic meter \\
cubic foot per second $\left(\mathrm{ft}^{3} / \mathrm{s}\right)$ & 0.02832 & cubic meter per second \\
cubic foot per second per square mile $\left.\left[\left(\mathrm{ft}^{3} / \mathrm{s}\right) / \mathrm{mi}^{2}\right)\right]$ & 0.01093 & cubic meter per second per square kilometer \\
foot $(\mathrm{ft})$ & 0.3048 & meter \\
foot per day $(\mathrm{ft} / \mathrm{d})$ & 0.3048 & meter per day \\
foot per mile $(\mathrm{ft} / \mathrm{mi})$ & 0.1894 & meter per kilometer \\
foot squared per day $\left(\mathrm{ft}^{2} / \mathrm{d}\right)$ & 0.09290 & meter squared per day \\
gallon per day $(\mathrm{gal} / \mathrm{min})$ & 0.06309 & liter per second \\
inch (in.) & 25.4 & millimeter \\
mile $(\mathrm{mi})$ & 1.609 & kilometer \\
square mile $\left(\mathrm{mi}^{2}\right)$ & 2.590 & square kilometer \\
\hline
\end{tabular}

\section{VERTICAL DATUM}

Sea Level: In this report, "sea level" refers to the National Geodetic Vertical Datum of 1929-a geodetic datum derived from a general adjustment of the first-order level nets of the United States and Canada, formerly called Sea Level Datum of 1929. 


\title{
Geohydrology of Stratified Drift and Streamflow in the Deerfield River Basin, Northwestern Massachusetts
}

\author{
By Paul J. Friesz
}

\section{Abstract}

This report presents the results of a study of the geohydrology of stratified drift and streamflow in the Deerfield River Basin, northwestern Massachusetts. Detailed hydrologic information is needed to plan for the optimal use of ground-water and surface-water resources and for development of new drinking-water supplies in the basin.

Sources and percentage of water available for recharge on an annual basis from October 1993 to September 1994, to the fine-grained stratifieddrift in a narrow valley bordered by upland till and bedrock were: (1) direct infiltration of precipitation on the valley ( 30 percent); (2) tributary loss from an upland brook as it crosses the valley ( 7 percent); and (3) ground- and surface-water runoff from the uplands ( 63 percent). Seventy percent of recharge was available from upland sources. Seasonal variation in recharge caused changes in groundwater levels and flow directions. In early spring, the direction of flow is toward the valley axis, but in late summer, the direction of flow is nearly parallel to the valley axis. Field observations and results of a ground-water flow simulation indicated that water available for recharge was greater than actual recharge during the spring snowmelt and during intense precipitation events. In 1994, estimates of water available for recharge were greater than actual recharge by 10 percent in March and by 60 percent in April; actual recharge to the valley on an annual basis from October 1993 to September 1994 was 20 percent less than original estimates.

A map showing thickness of stratified drift in the Connecticut Valley Lowlands indicates a deep north-south trending buried valley. Maximum thickness of the stratified drift is 385 feet. Interpretation of a seismic-reflection survey indicates fine-grained stratified drift may be underlain by coarse-grained deposits ranging in thickness from 0 to 150 feet.

Hydraulic properties of the stratified drift were calculated from ground-water-level fluctuations induced by river stage changes using a ground-water-flow model for a site adjacent to the Deerfield River. A comparison of measured and simulated heads resulted in a vertical riverbed hydraulic conductivity of 3 feet per day, anisotropic ratio of horizontal to vertical hydraulic conductivity of $40: 1$, and storage of 0.040 and 0.0002 for the unconfined and confined layers of the stratified drift. Hydraulic diffusivity (transmissivity divided by the unconfined storage) at the site is about 168,000 feet squared per day.

Streamflows at times of low flow were determined for 27 sites that drain areas ranging from 0.57 to 15.8 percent stratified drift.

Streamflows exceeded between 80 and 99 percent of the time were determined for sites on the unregulated tributaries to the Deerfield River. Streamflows per square mile of drainage area were greatest from sites at the downstream ends of the North River-Colrain and the Deerfield River-Charlemont stratified-drift valleys.

Flow-duration curves for three continuous streamflow-gaging stations on the regulated Deerfield River were compared to flow-duration curves for three continuous streamflow-gaging stations on unregulated tributaries to show the effects of dam regulation on streamflow. Flow-duration curves constructed using instantaneous discharges for the three regulated gaging stations have flat sections that correspond to the predominant streamflows when water is being released from storage from the dams. 


\section{INTRODUCTION}

The Deerfield River Basin covers an area in northwestern Massachusetts that includes all or a part of 20 towns (fig. 1). Eight towns obtain public-water supplies from sources in the basin; most of these eight towns derive their supplies from a combination of ground-water and surface-water sources. Concerns about the ability of current surface-water supplies to meet recently instituted Federal drinking-water standards has caused some towns to consider replacing their surface-water supplies with ground water. In the Berkshire Hills, the stratified drift in the narrow river valleys is a potential source of ground water. In the Connecticut Valley Lowlands, much of the thickness and lithology of the stratified drift is unknown. In parts of the Connecticut Valley Lowlands outside of the study area, coarse-grained stratified drift that underlies fine-grained stratified drift is a major source of publicwater supplies. Optimal development and use of ground-water resources in the basin requires an increased understanding of the geohydrology of the stratified drift.

Water from the Deerfield River is used extensively for hydroelectric-power generation. In recent years, recreational uses, such as fishing, canoeing, and whitewater activities, have become increasingly popular in the rivers and streams of the basin. Balancing the needs of these potentially competing users with the in-stream flow needs of fish and wildlife requires an increased understanding of the flow characteristics of the Deerfield River and its tributaries.

The U.S. Geological Survey, in cooperation with the Massachusetts Department of Environmental Management, Division of Resource Conservation, Office of Water Resources (MOWR), began a 3-year study in 1992 to quantitatively assess the water resources and to increase understanding of hydrologic processes in the Deerfield River Basin. The study was one in a series of studies of the hydrology of the State's 27 river basins initiated through the Chapter 800 Acts of the Massachusetts legislature in 1979. Information from this report can be used by the MOWR and the towns in the basin to develop water-management plans.
Efficient management of ground-water and surface-water resources requires information and knowledge about several physical characteristics and hydrologic processes, including the geometry, hydraulic properties, and recharge of stratified drift, and streamflow characteristics. The potential for groundwater development in the Connecticut Valley Lowlands relates to the thickness of the stratified drift and the distribution of coarse-grained sediments. Management of ground-water resources in valley-filled settings requires an understanding of the hydraulic properties of the stratified drift and stream sediments to confidently predict the effects of pumping on streamflow and the contribution of water from streams to wells. In addition, the water-development potential of stratified-drift valleys depends on the quantity of recharge from various sources, including direct infiltration of precipitation, streamflow loss from tributary streams, and ground-water and surface-water runoff from upland till and bedrock. Streamflow characteristics, particularly during low-flow periods, are needed to determine the effects of diversions, either directly from streams or by pumping of ground water, on stream habitat.

\section{Purpose and Scope}

This report presents the results of a study of the geohydrology of stratified drift and streamflow in the Deerfield River Basin. The study area is the surfacewater drainage basin of the Deerfield River in northwestern Massachusetts; however, some streamflow measurements were made at sites whose drainage area extends into Vermont.

The geohydrology is described by (1) preparing a map of the areal extent and thickness of stratified drift and locating areas of coarse-grained stratified drift in the Connecticut Valley Lowlands, (2) determining hydraulic properties of stratified drift at a site adjacent to the Deerfield River, and (3) determining recharge to a stratified-drift valley bordered by upland till and bedrock, and its seasonal variability. Streamflow is characterized by (1) presenting flow-duration curves to indicate the effects of dam regulation on flow in the Deerfield River and (2) quantifying streamflow from selected subbasins during periods of low flow. 


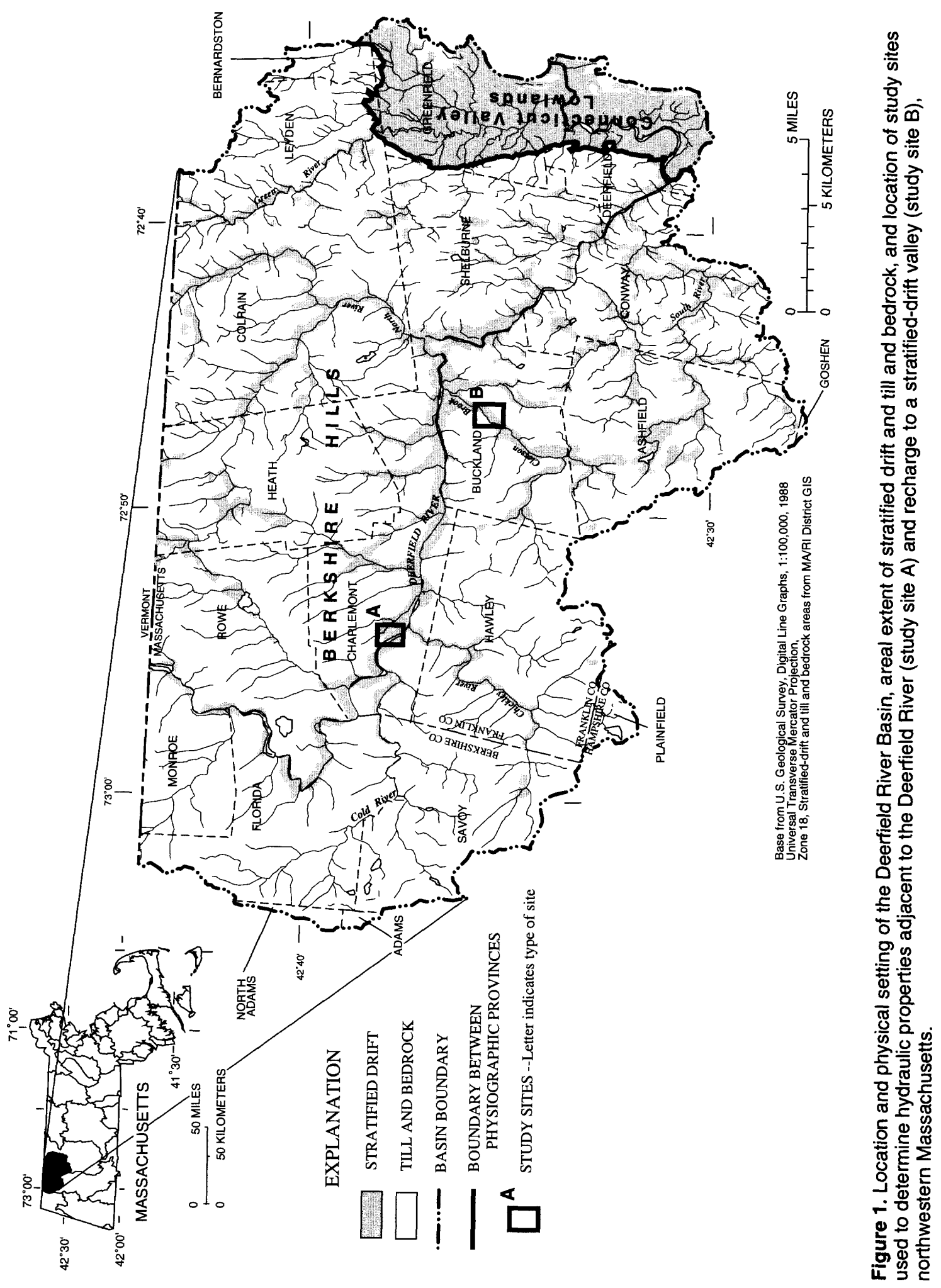




\section{Previous Investigations}

Previous regional investigations of the Deerfield River Basin by the U.S. Geological Survey, in cooperation with the Massachusetts Department of Environmental Management, resulted in a hydrologic-data report by Hansen and others (1973) and a hydrologic atlas by Gay and others (1974). The hydrologic atlas described the ground-water resources, streamflow, and water quality of the basin. Other studies on a regional scale produced a gazetteer that described the hydrologic characteristics of streams (Wandle, 1984), a report by the Franklin County Planning Department (1990), which focused on a narrow corridor along the mainstem of the Deerfield River, and a report by the town of Greenfield and the Green River Watershed Protection Alliance (Walk and others, 1992) concerning the Green River, a major tributary to the Deerfield River. Local-scale studies that describe water resources have been completed by consultants for several towns. In addition, reports on numerous studies of watercontamination sites by consultants are available from site assessment files at the Massachusetts Department of Environmental Protection.

\section{Geographic Setting}

The Deerfield River, a tributary to the Connecticut River, drains $663 \mathrm{mi}^{2}$ of northwestern Massachusetts and south-central Vermont. More than one-half of the Deerfield River Basin, $347 \mathrm{mi}^{2}$, is in Massachusetts and includes most of Franklin County and parts of Berkshire and Hampshire Counties (fig. 1). Most of the drainage area is in the Berkshire Hills physiographic province (Fenneman, 1938) where the landscape consists of narrow river valleys bordered by steep hillslopes. The southeastern part of the basin is part of the Connecticut Valley Lowlands physiographic province (Fenneman, 1938) where the topography is flatter than the Berkshire Hills. Land-surface altitudes in the basin range from $120 \mathrm{ft}$ above sea level in the Connecticut Valley Lowlands to 2,841 $\mathrm{ft}$ above sea level in the Berkshire Hills. Average annual precipitation ranges from $44 \mathrm{in}$. in the low altitudes of the southeast to 50 in. in the high altitudes in the western part of the basin (Knox and Nordenson, 1955). Major tributaries to the Deerfield River, in order of decreasing drainage area, are the North River $\left(92.9 \mathrm{mi}^{2}\right)$, Green River $\left(89.8 \mathrm{mi}^{2}\right)$, Cold River $\left(31.7 \mathrm{mi}^{2}\right)$, Chickley River $\left(27.4 \mathrm{mi}^{2}\right)$, South River $\left(26.3 \mathrm{mi}^{2}\right)$, and Clesson Brook $\left(21.2 \mathrm{mi}^{2}\right)$.

In 1990, the population in this rural basin was about 35,300 , with more than 50 percent of the population in the town of Greenfield (18,666 people) in the Connecticut Valley lowlands (U.S. Department of Commerce, 1991). The basin is covered primarily by forest ( 81 percent); agriculture and open land (13 percent), urban development (4 percent) and surface water ( 2 percent) constitutes the remaining part of the basin.

The steep gradient of the Deerfield River in the Berkshire Hills creates an environment favorable for hydroelectric power generation. Dams at the hydroelectric-power generating stations in Massachusetts provide only a small amount of stored water; most water used to operate the generating stations is stored in reservoirs built on the headwaters of the Deerfield River in Vermont (Gay and others, 1974). Water released from the dams affects the entire range of streamflow and causes multiple daily stream stage fluctuations. A profile showing the altitude of the Deerfield River and the location of hydroelectric developments, streamflow-gaging stations, and confluences with the major tributaries is shown in figure 2 . The river gradient averages $28.4 \mathrm{ft} / \mathrm{mi}$ from the Vermont border to the streamflow-gaging station at West Deerfield, a distance of about 33 river miles.

\section{Geohydrologic Setting}

Bedrock, composed of mostly metamorphic rock in the Berkshire Hills and mostly sedimentary rock in the Connecticut Valley Lowlands, underlies the Deerfield River Basin. Households in the basin not connected to public-water supplies derive most of their water from individual bedrock wells. In general, wells completed in metamorphic rock can produce about $5 \mathrm{gal} / \mathrm{min}$ and wells completed in sedimentary rock can produce about 10 to $80 \mathrm{gal} / \mathrm{min}$ (Gay and others, 1974). Water from metamorphic rock is derived from interconnected fractures whereas water from sedimentary rock is derived from interconnected fractures and pore spaces. 


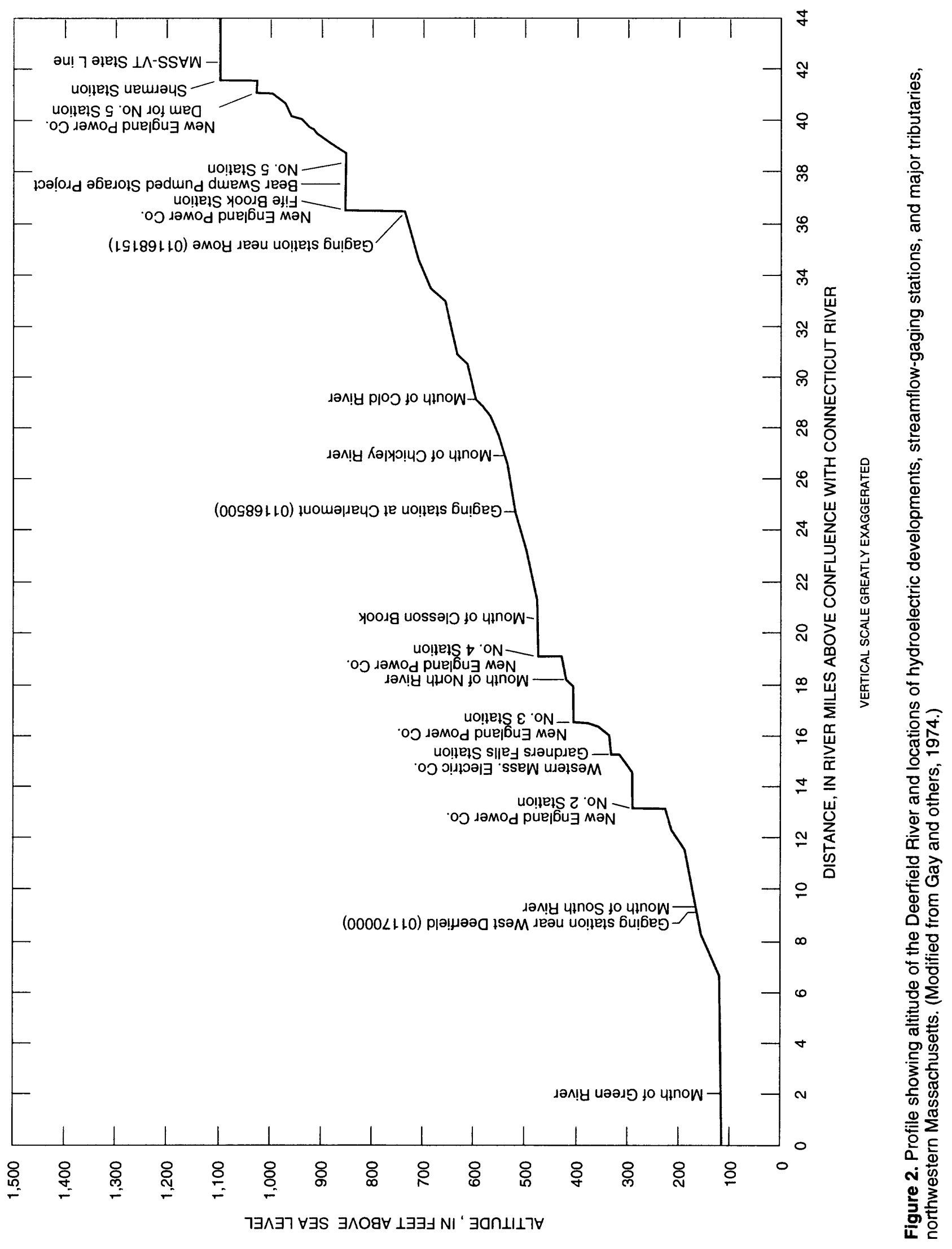


Sediments of glacial origin-till and stratified drift-overlie the bedrock. A thin, discontinuous layer of till deposited directly on the bedrock by glaciers is composed of a poorly sorted mixture of sediments that can range in size from clay to boulders. Because the poorly sorted sediments have low hydraulic conductivity, till generally transmits only small quantities of water.

Stratified drift consists of well-sorted, layered sediments deposited by glacial meltwater. Alluvial deposits from postglacial streams are categorized with stratified drift in this report. The areal extent of the stratified drift is shown in figure 1. Most stratified drift is in the narrow river valleys of the Berkshire Hills and in the broad valley of the Connecticut Valley Lowlands. Coarse-grained stratified drift, consisting primarily of sand and gravel, is the most favorable material for public-water supplies; in areas of thick, saturated coarse-grained stratified drift, wells have produced as much as $1,000 \mathrm{gal} / \mathrm{min}$ (Gay and others, 1974). Fine-grained stratified drift consisting of clay, silt, and fine sand has low hydraulic conductivity and generally transmits only small quantities of water.

In the Connecticut Valley Lowlands, most of the known lithology indicates the stratified drift is predominately fine-grained lake-bottom deposits formed in Glacial Lake Hitchcock. However, in some locations coarse-grained stratified drift underlies the lake-bottom deposits. In addition, deltaic deposits, where tributary streams entered the glacial lake, and shore deposits of the lake, consist of coarse-grained stratified drift that overlies the lake-bottom deposits (Jahns, 1966).

\section{Acknowledgments}

The author thanks the town, county, and State employees for providing results of hydrologic studies. The author expresses appreciation to the towns, Massachusetts Highway Department, private landowners, and especially the Buckland Historical Society for granting access to land to collect ground-water, surface-water, and seismic-refraction data. The author also thanks New England Power Company for regulating the flow on the Deerfield River to enable completion of a seismic-reflection survey, and for providing climatological data.

\section{GEOHYDROLOGY OF STRATIFIED DRIFT}

The geohydrology of stratified drift in the Connecticut Valley Lowlands was investigated by describing the areal extent, thickness, and lithology using surface geophysics and historical hydrologic data. The geohydrology of selected stratified drift in the Berkshire Hills was investigated by determining hydraulic properties at a site adjacent to the Deerfield River and recharge to a valley filled with stratified drift and bordered by upland till and bedrock using ground-water, surface-water, and climatological data.

\section{Areal Extent, Thickness, and Lithology of Stratified Drift in the Connecticut Valley Lowlands}

A map of the areal extent and thickness of stratified drift in the Connecticut Valley Lowlands was prepared using results from seismic-refraction and seismic-reflection surveys done for this study and from historical hydrologic data compiled since the maps by Gay and others (1974) and Londquist (1975) were completed. Lines of equal thickness from the map prepared by Londquist (1975) for most of the central and southern part of the lowlands and from the map prepared by Gay and others (1974) for the remaining part of the lowlands were revised using the data collected during this study. A transmissivity map, prepared by Gay and others (1974), was not updated because of a lack of available data to make significant revisions; however, areas of possible coarse-grained stratified drift favorable for development of ground-water supply were determined from the seismic-reflection survey.

The data used to prepare a map of stratified-drift thickness and locate coarse-grained deposits are shown on plate 1 and includes:

1. Seismic-refraction surveys were done to determine the areal extent and thickness of the stratified drift and to provide velocity data to aid in interpreting a seismic-reflection survey. Seismicrefraction surveys at four sites ( $\mathrm{pl} .1$ ) totaled $8,900 \mathrm{ft}$ in length and were interpreted using a computer program that incorporated delay-time and ray-tracing techniques developed by Scott and others (1972). Available lithologic logs from 
nearby wells and borings were used to verify parts of the interpreted surveys. Geohydrologic sections from the interpreted surveys are shown in appendix A (fig. A1). Thickness of the stratified drift ranged from 26 to $314 \mathrm{ft}$.

2. A seismic-reflection survey was completed to determine the areal extent and thickness of stratified drift and to qualitatively determine lithology of the stratified drift along $7.4 \mathrm{mi}$ of the Deerfield River from Interstate Highway 91 to the river's confluence with the Connecticut River (pl. 1). The quality of the seismicreflection record is primarily dependent on the river-bottom sediments. Depending on the type of sediment, sound-source energy may be scattered or absorbed, thereby preventing sufficient penetration to underlying layers resulting in a weak or no record. The record was interpreted based on the pattern of the reflected signal and its corresponding geologic interpretation described in Haeni (1988). Available lithologic logs from nearby wells and borings, and bedrock outcrops, were used to verify segments of the interpreted record. Geohydrologic sections from the interpreted record are shown in appendix $\mathrm{A}$ (fig. A2). Thickness of the stratified drift ranged from 0 to $385 \mathrm{ft}$.

3. Historical hydrologic data were used to confirm interpretations of surface geophysics and to determine the areal extent and thickness of the stratified drift. Lithologic logs from wells and borings completed for municipalities and private landowners since the previous investigations were compiled and entered into the U.S. Geological Survey's national database [Ground Water Site Inventory (GWSI)]. Sources of data included drillers' logs from the Massachusetts Department of Environmental Management, Office of Water Resources, and consultant reports from the Massachusetts Department of Environmental Protection site assessment files and town departments. Locations of the wells and borings are shown on plate 1 . In addition to the lithologic logs, interpreted seismic-refraction surveys were available from three consultant reports prepared for two municipalities
(Almer Huntley, Jr., and Associates, Inc., 1986; G.H. McDonnell, Tighe and Bond, Inc., written commun., 1987; Tighe and Bond Inc., 1992).

The thickness of stratified-drift in the Connecticut Valley Lowlands is shown on plate 1. Because of the regional scale of the investigation, the thicknesses are approximate. In some areas, the stratified drift may include thin layers of till, so that the thickness of stratified drift will be slightly overestimated. The 10-foot line of equal thickness on the hillsides may consist primarily of till deposits. Thicknesses in the southern half of the study area were substantially revised; thicknesses are much greater than in the map by Londquist (1975), indicating a deep buried valley trending north to south. In the town of Deerfield, between the Deerfield River and Routes 5 and 10, the stratified drift is thickest in an area of glacial overdeepening, where the bedrock surface (land-surface altitude minus stratified-drift thickness) is at greater depths than the surrounding bedrock valley surface to the north and south.

Results of the interpreted seismic-reflection record indicate that fine-grained lacustrine deposits may be underlain by coarse-grained stratified drift in some areas. As the Deerfield River meandered across the valley floor, the seismic-reflection record indicated a buried valley, possibly filled by coarse-grained stratified drift between reference numbers 4 and 31 (appendix A, fig. A2). The coarse-grained stratified drift ranges in thickness from 0 to $150 \mathrm{ft}$. The seismicreflection record and its interpretation for a part of this area is shown in figure 3. A lithologic log from DFW96 (fig. 3, location of well shown on pl. 1) verified the interpretation of the seismic-reflection record which indicated that coarse-grained deposits underlie finegrained deposits. This 8 -inch diameter well, which has a 15-feet screen in the coarse-grained deposits, yields $205 \mathrm{gal} / \mathrm{min}$ (at a drawdown of $160 \mathrm{ft}$ ) (Michael Havener, Layne-New England Co., written commun., 1981). The estimated areal extent of the buried coarsegrained stratified drift, determined from data collected during this study in the southern half of the study area, is shown on plate 1. Locations of ground-water sources used for public-water supplies in the Connecticut Valley Lowlands also are shown on plate 1. Municipal water-supply wells in the southern part of the mapped area are screened in shallow coarse-grained deposits and not in the buried coarse-grained deposits. 

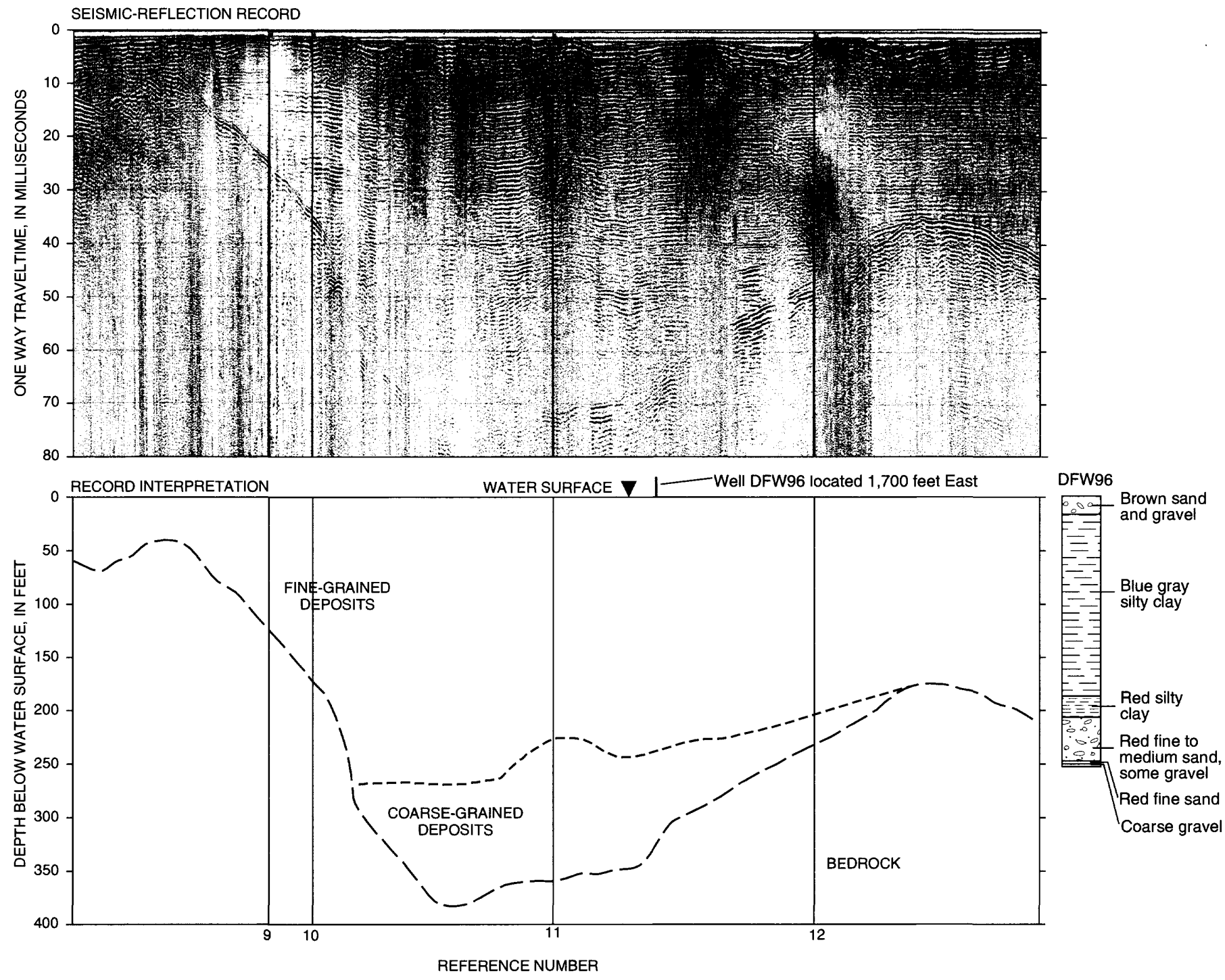

Figure 3. Seismic-reflection record, record interpretation, and a lithologic log from well DFW96, Deerfield River Basin, northwestern Massachusetts. (Location of well and reference numbers are shown on plate 1.)

\section{Hydraulic Properties of Stratified Drift at a Site Adjacent to the Deerfield River}

Hydraulic properties of the stratified drift, including the degree of connection between the Deerfield River and the surrounding material, were determined from the response of ground-water levels to fluctuations in river stage. Storage water released from dams built on the river causes the river stage to fluctuate, which in turn induces ground-water levels to change in the adjacent hydraulically connected stratified drift.
A cross-sectional finite-difference model (McDonald and Harbaugh, 1988) was used to estimate hydraulic properties by simulating head changes in the stratified drift from July 5-7, 1994. The simulated heads were compared to measured heads; comparisons between the simulated and measured heads provided a basis for trial-and-error adjustments for the hydraulic properties. Because the hydraulic properties are interdependent, the final calibrated model does not provide a unique solution. However, hydraulic 
properties determined for the study site provide an understanding of the hydrology of the stream-aquifer system and are most likely representative of stratified drift adjacent to the Deerfield River and of similar valley-filled sediments in other parts of the basin.

\section{Description of Study Site}

The study site, upstream from the town center of Charlemont and adjacent to the Deerfield River, is near the upstream end of a narrow, stratified-drift-filled valley about $10 \mathrm{mi}$ long (fig. 1 and 4). Lithology of the stratified drift, determined from sediment samples and shown in a geohydrologic section (fig. 5), consists of four different types: (1) a thin, fine sand layer at the land surface, (2) a coarse sand to boulder layer 6.5 to $8.5 \mathrm{ft}$ thick, (3) a well-sorted fine sand and medium sand layered material of varying thickness, and (4) a very fine sand with trace gravel material also of varying thickness. Depth to the metamorphic bedrock, about $90 \mathrm{ft}$, was estimated on the basis of a seismicrefraction survey completed on the opposite side of the river (Hansen and others, 1973). The water table fluctuates solely within the coarse sand to boulder layer. The riverbed consists of material similar to the coarse sand to boulder layer.

Ground-water levels were recorded at 5-minute intervals at observation wells installed in two well clusters in a line perpendicular to the river (fig. 4). One cluster of wells is at the riverbank, about $10 \mathrm{ft}$ from the river edge, and the far cluster is $126 \mathrm{ft}$ away from the riverbank cluster (fig. 5). Each well cluster consists of three observation wells screened at different depths: one at the water table, one at the medium depth, and one in the deep part of the stratified drift. The mediumdepth and deep observation wells have 4-foot-long screens. Surface-water levels were measured intermittently from a reference point in the river. Surface-water levels between measurements were interpolated using records from a continuous streamflow-gaging station (Deerfield River at Charlemont, Mass., 01168500) about $3 \mathrm{mi}$ downstream in a channel of similar dimensions.

During July 5-7, 1994, flows released from an upstream dam fluctuated between 960 and $125 \mathrm{ft}^{3} / \mathrm{s}$ (Jim Atomanuk, New England Power Co., written commun., 1994); the large releases lasted about 12 and
10 hours, while the subsequent small releases lasted about 15 and 13.5 hours. The corresponding range in river stage was $1.49 \mathrm{ft}$ at the study site (fig. 6). The river stage rose abruptly as high-flow releases arrived at the site but declined gradually after the dam release was completed, probably due to the draining of water from bank storage. Ground-water levels respond to these changes in river stage and indicate that the stratified drift is hydraulically connected to the river. A rise in river stage of $1.49 \mathrm{ft}$ caused a corresponding change of $1.06 \mathrm{ft}$ in the water-table well at the riverbank; however, water-level changes farther from the river decrease in magnitude. The vertical-head gradient at the riverbank well cluster reverses direction due to these changes in river stage, indicating ground-water flow changes direction beneath the river. The horizontal-head gradient between the river and the far water-table well, and between both water-table wells, indicates flow was away from the river during July 5-7, 1994 , even during low river stages. The river reach was losing water probably because the site is at a pooled section of the channel between riffles. In addition, minimum streamflow released from the upstream dam may have been larger than streamflow that would naturally occur from ground-water discharge during this period.

\section{Hydraulic Properties Determined from Simulation of Ground-Water and Surface-Water Interactions}

A two-dimensional cross-sectional finitedifference model (McDonald and Harbaugh, 1988) was used to simulate ground-water and surface-water interactions from July 5-7, 1994. The model represents a vertical cross section oriented perpendicular to the river, extending from the midpoint of the river through the observation wells (fig. 4). The model boundary was extended to the valley wall to minimize the effects of boundary conditions on simulated heads near the far cluster. The predominant head changes caused by the fluctuating river stage were assumed to propagate normal to the river; only the changes in head due to the river stage were simulated and not the complex three-dimensional ground-water-flow system. 


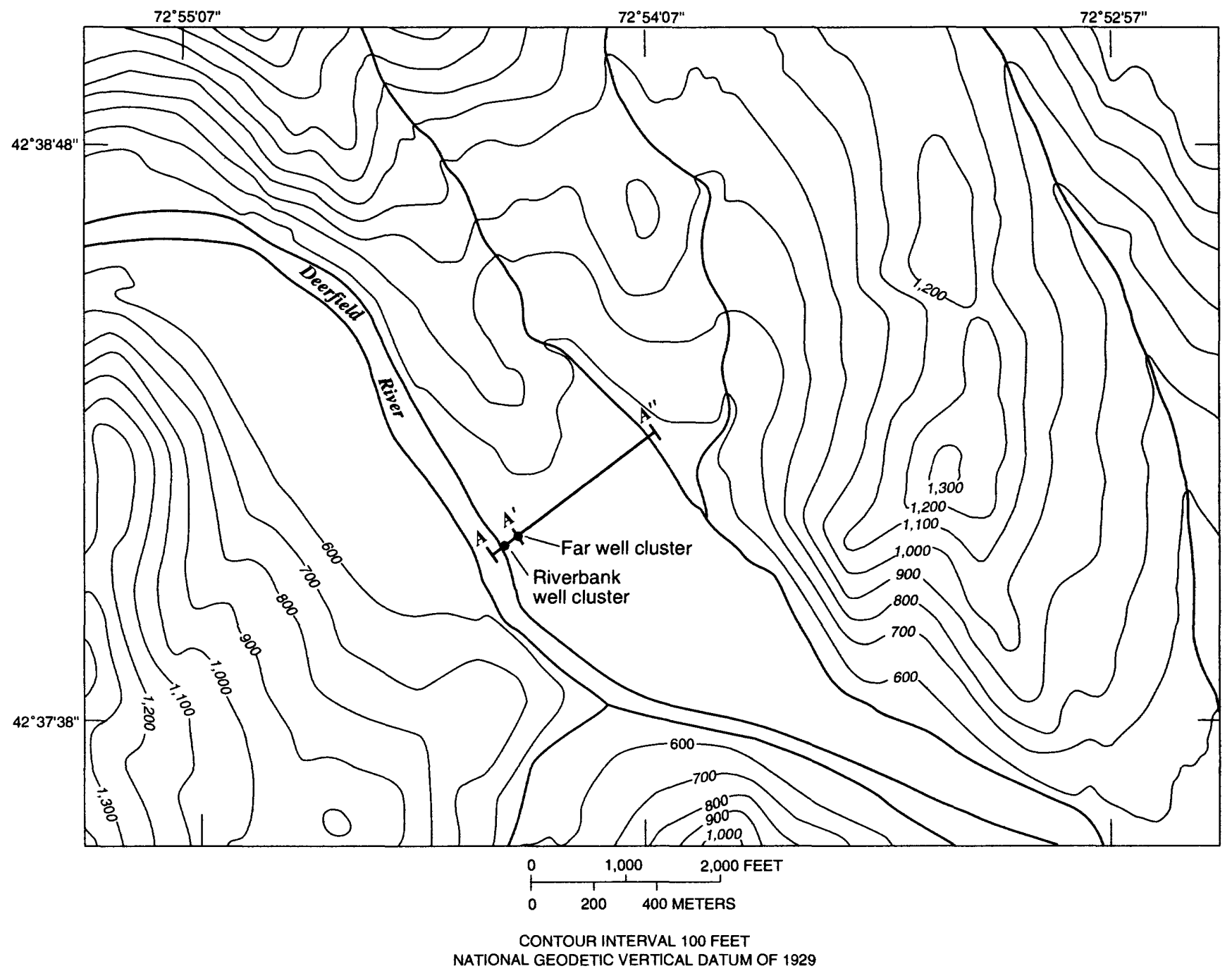

EXPLANATION

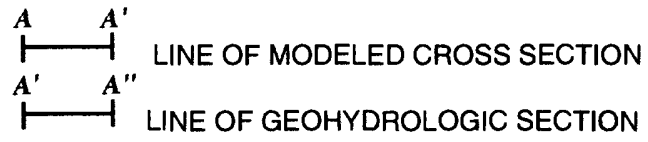

- observation WELl Cluster site

Figure 4. Location of observation well cluster sites and section lines adjacent to the Deerfield River, northwestern Massachusetts. (See figure 1 for location of study site A.) 

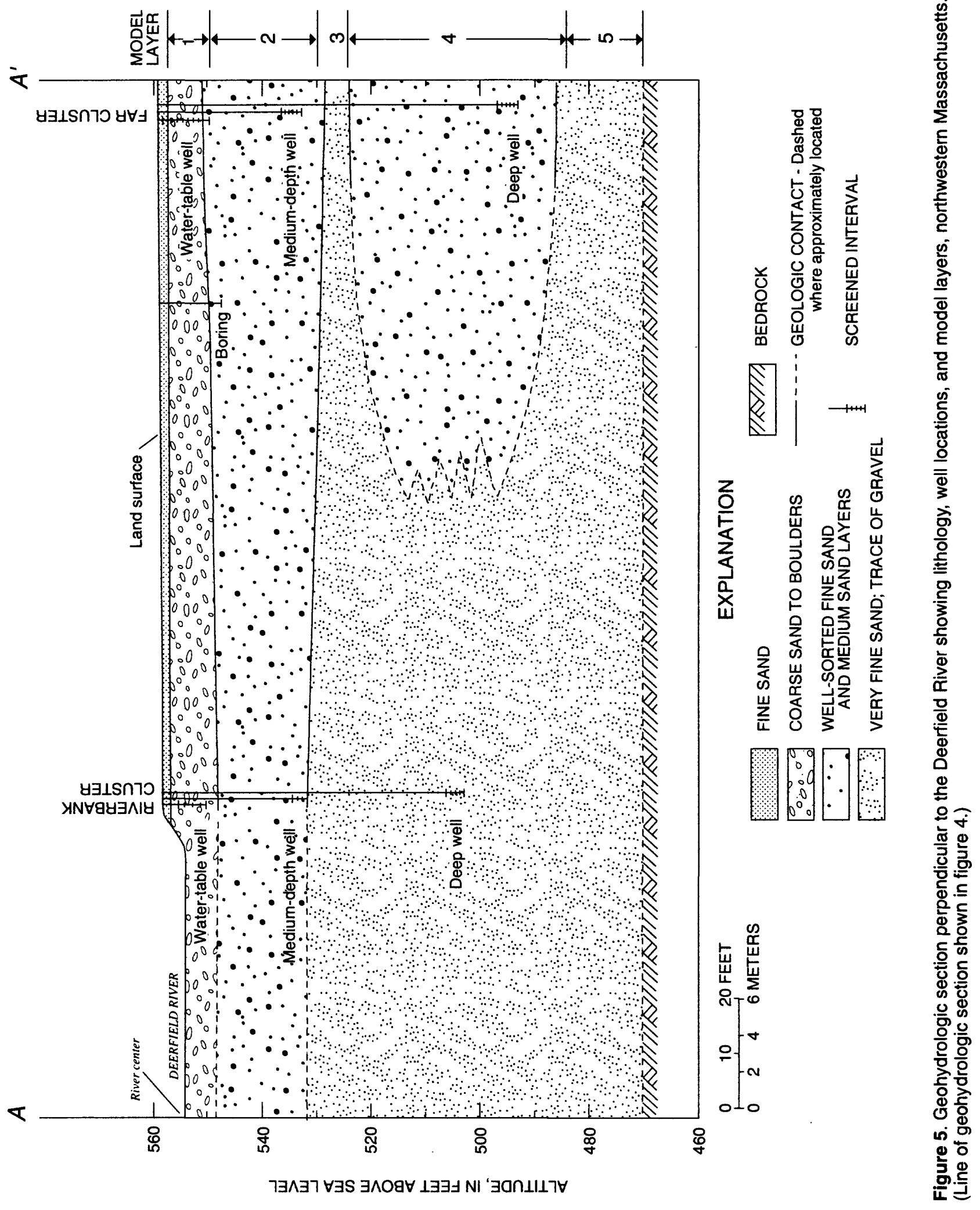


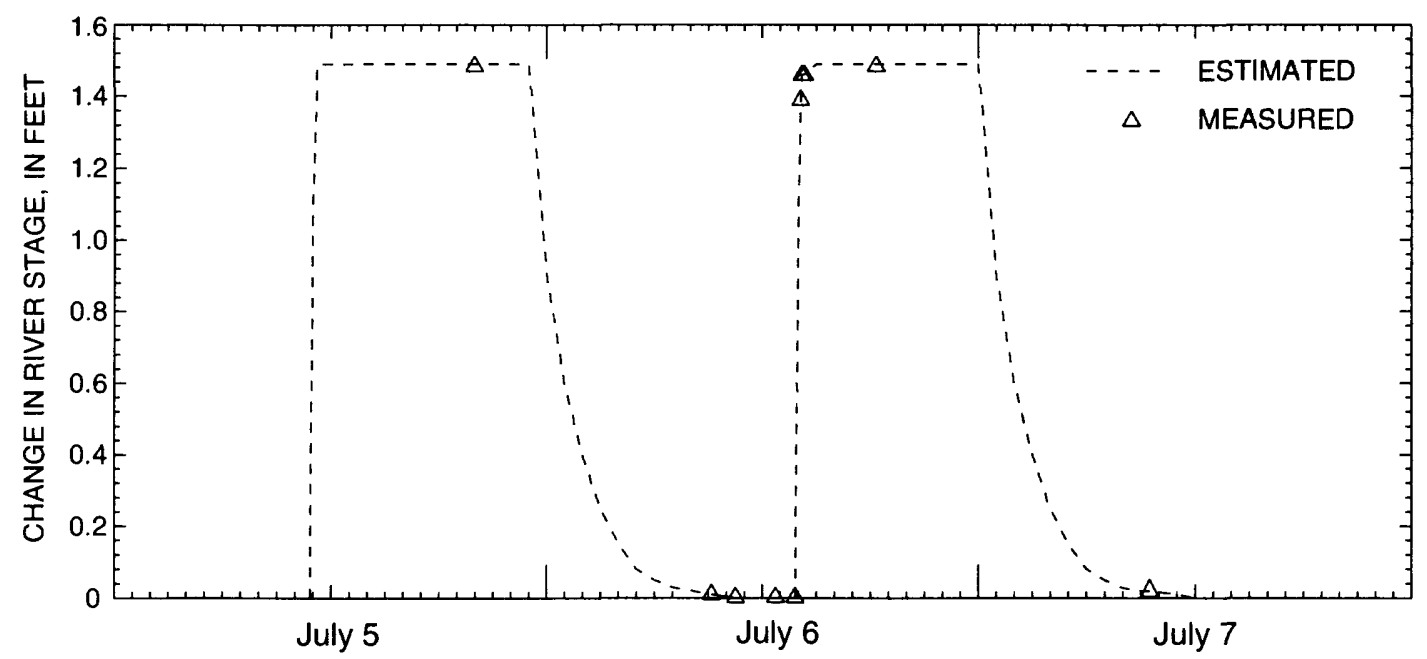

Figure 6. Changes in stage of the Deerfield River, northwestern Massachusetts, July 5-7, 1994.

\section{Description of Model}

The stratified drift is represented by a crosssectional, five-layered, variable rectangular grid; the columns are $10 \mathrm{ft}$ wide from the midpoint of the river to the far cluster and then gradually increase to $100 \mathrm{ft}$. The vertical layering is based on the lithology and well-screen placements (fig. 5): layer 1 represents the unconfined coarse sand to boulder layer and contains the river and the water-table wells; layer 2, which is $20 \mathrm{ft}$ thick, represents the well-sorted fine sand and medium sand layer unit and contains the medium-depth wells; layers 3 and 5 represent very fine sand with a trace of gravel, and were 5 and $15 \mathrm{ft}$ thick, respectively; and layer 4 , which is $40 \mathrm{ft}$ thick, represents the well-sorted fine sand and medium sand layered material and the very fine sand with trace gravel material and also contains the deep wells. All model layers except layer 1 are confined by the overlying model layers.

The vertical sides and the bottom of the model were simulated as no-flow boundaries. The vertical boundary beneath the midpoint of the river was represented by a no-flow boundary because flow on the other side of the partial-penetrating stream is assumed to recharge and discharge through the other half of the river. Vertical sides of the cross section normal to the river are no-flow boundaries because these boundaries are based on the assumption that flow is parallel to the cross section. The geologic contact between the permeable stratified drift and the relatively impermeable bedrock also is represented as a no-flow boundary.

The flow of water between the river and the stratified drift was simulated using a hydraulically conductive riverbed and a riverbed thickness of $1 \mathrm{ft}$ (the actual thickness is unknown). The river-stage hydrograph was simulated in steps. High stages were represented by one step while low stages were approximated by three steps because of the hydrograph recession. The remainder of the top boundary, the water-table position, is computed by the model. Recharge was not simulated because no precipitation fell during the 2-day period that the model simulates nor during the previous 4 days.

Initial conditions for each new set of model parameters were established by simulating the previous 6 days of river-stage fluctuations. These 6 days alternated between six high and six low stages. Heads at the end of the 6 days were used as initial heads for the July 5-7, 1994, simulation.

The model was calibrated by adjusting model parameters until the simulated heads agreed closely with the measured heads at the six observation wells. The hydraulic properties estimated by model calibration were (1) vertical hydraulic conductivity of the riverbed, (2) anisotropic ratio of the horizontal to vertical hydraulic conductivity of the stratified drift, and (3) storage of the unconfined and confined layers. 
The anisotropic ratio was held uniform between all five layers. Storage for each of the four confined layers also was held uniform. Storage in the confined layers is due to the compression and expansion of the water and the stratified drift. In the unconfined layer, in addition to the compression and expansion, storage is predominately due to water draining from or filling the pores at the water table (specific yield) (Lohman and others, 1972). Because the hydraulic properties are interdependent and because the horizontal hydraulic conductivity could reasonably be estimated from detailed lithologic logs, horizontal hydraulic conductivity was not determined by model calibration. The horizontal hydraulic conductivity was estimated as $400 \mathrm{ft} / \mathrm{d}$ for the coarse sand to boulder layer, $100 \mathrm{ft} / \mathrm{d}$ for the well-sorted fine sand and medium sand material, and $25 \mathrm{ft} / \mathrm{d}$ for the very fine sand with trace gravel material.

\section{Results of Model Calibration}

Results of the calibrated model are shown by comparing hydrographs of the simulated and measured heads (fig. 7). The hydrographs show the change in head in the six observation wells using water levels at the start of the first river-stage rise as the datum. The hydraulic properties used in the calibrated model were a vertical riverbed conductivity of $3 \mathrm{ft} / \mathrm{d}$, an anisotropic ratio of the horizontal to vertical hydraulic conductivity of $40: 1$, and storage of 0.040 and 0.0002 for the unconfined and confined layers, respectively. The resulting hydraulic diffusivity (transmissivity divided by the unconfined storage) of the site is about $168,000 \mathrm{ft}^{2} / \mathrm{d}$. At five of the six observation wells, simulated and measured heads compare reasonably. However, at the medium-depth riverbank well, the simulated head overestimates changes in head and might be due to the coarseness of the model grid near the complex flow system of a partial penetrating river.

The initial response in the medium-depth and deep confined wells to the high river flow was not used in calibrating the model. This initial response, which includes a steep rise in hydraulic head followed by a slight decline in the first 45 minutes after the rise in river stage, probably is due to the added weight on the stratified drift resulting from the increased volume of river water. Similar ground-water-level changes due to the added weight of a train were described by Jacob (1939). Jacob explained that the added load compresses the aquifer, thereby increasing the hydrostatic pressure. Pressure decreases as water moves away from the load and the matrix of the aquifer supports proportionally more of the weight; the decrease in pressure is reflected in a lower hydraulic head.

The calibrated values of the hydraulic properties were varied within a reasonable range to assess their effects on the ground-water system. Only one calibrated property was changed at a time; all others were set at values used in the calibrated model. The effect of varying each calibrated property was assessed by comparing the total head change between the calibrated model and the model with the varied property during the river-stage rise of July 5 (table 1):

1. Vertical-hydraulic conductivity of the riverbed: Varying the vertical hydraulic conductivity by an order of magnitude, from $3 \mathrm{ft} / \mathrm{d}$ to 0.3 and $30 \mathrm{ft} / \mathrm{d}$, caused the greatest effects on heads near the river, as indicated by the water table and medium-depth riverbank wells compared to wells farther from the river. River leakage decreased by 53 percent by decreasing the vertical hydraulic conductivity to $0.3 \mathrm{ft} / \mathrm{d}$. River leakage increased by 15 percent by increasing vertical hydraulic conductivity to $30 \mathrm{ft} / \mathrm{d}$. Decreasing the vertical conductivity of the riverbed produced greater head and river leakage changes than increasing it, probably because the larger riverbed vertical conductivity exceeds the vertical conductivity of the stratified drift. The flow of water between the river and the stratified drift is most likely controlled by the lowest value of vertical conductivity, whether it is the riverbed or the stratified drift.

2. Anisotropic ratio of the horizontal to vertical hydraulic conductivity of the stratified drift: Multiplying the anisotropic ratio by 0.25 and 4, from 40:1 to $10: 1$ and 160:1 caused the greatest effects on heads at the deep observation wells at both clusters and at the medium-depth riverbank well. The low anisotropic ratio, 10:1, increased the river leakage by 11 percent, and the high ratio, 160:1, decreased the river leakage by 9 percent. 

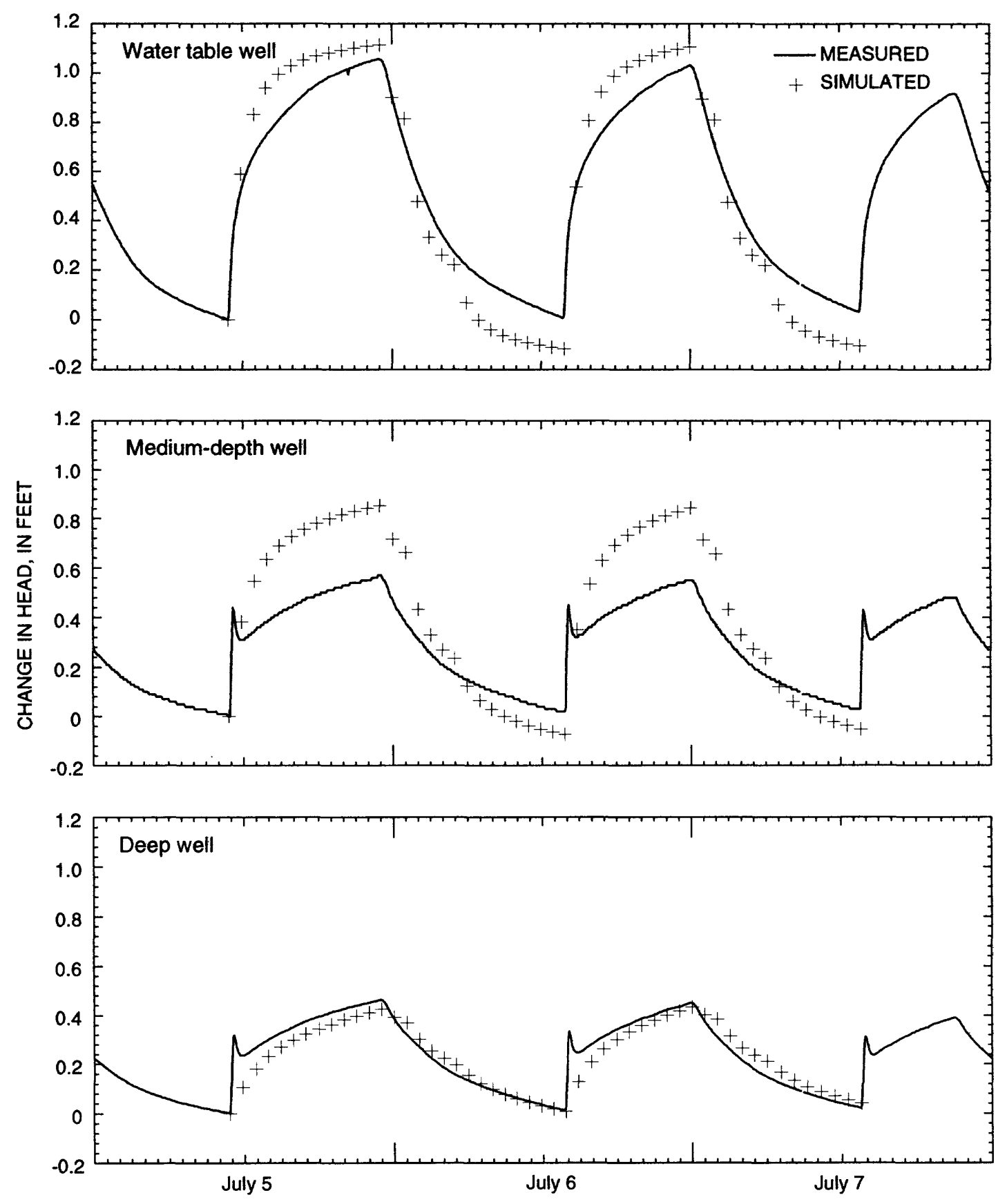

\section{A. RIVERBANK CLUSTER SITE}

Figure 7. Measured and simulated heads for $(A)$ riverbank and $(B)$ far cluster sites, Deerfield River Basin, northwestern Massachusetts, July 5-7, 1994. (Datum for each well is the ground-water level at the start of the first river-stage rise, July 5,1994 .) 

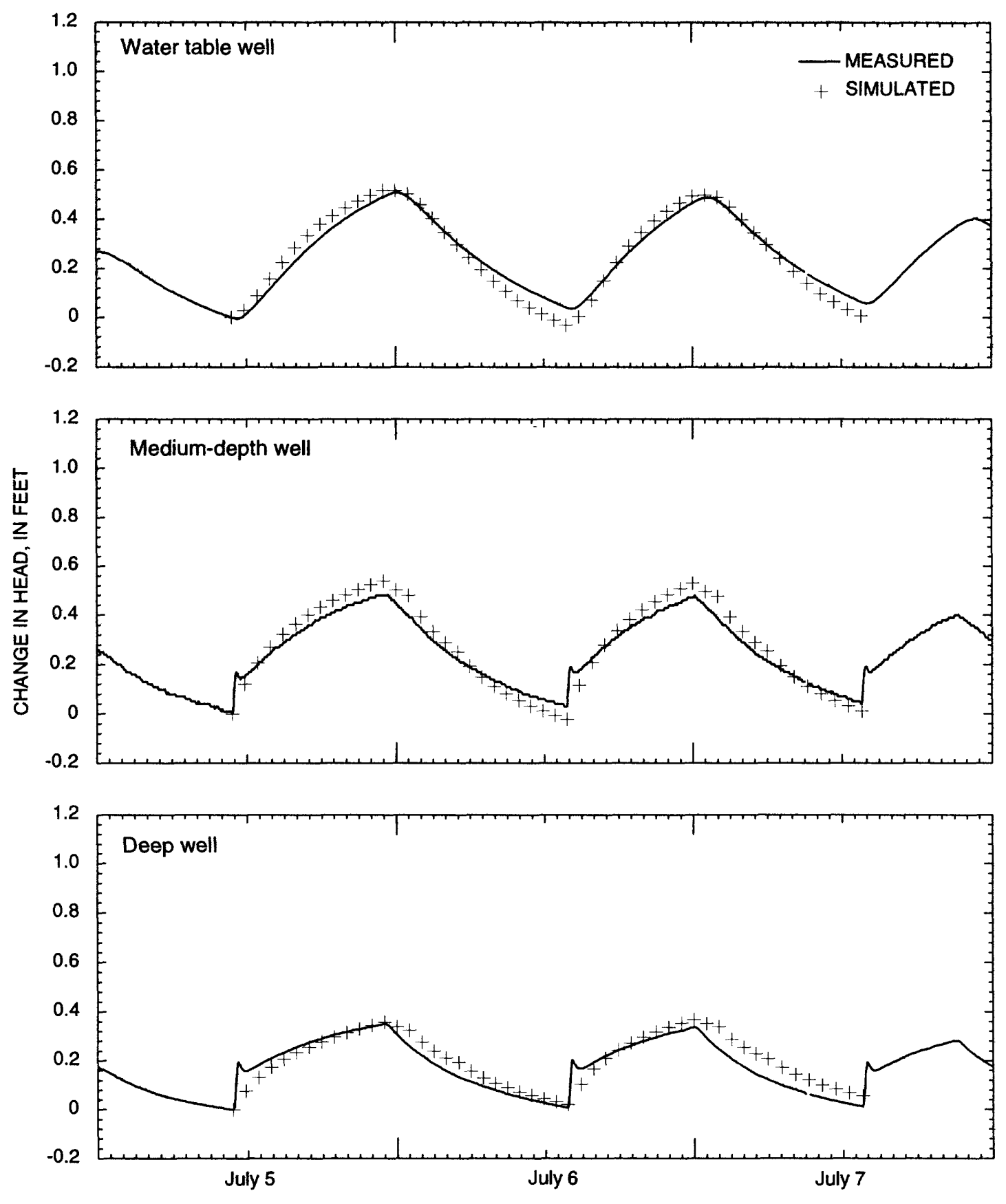

\section{B. FAR CLUSTER SITE}

Figure 7. Measured and simulated heads for $(A)$ riverbank and $(B)$ far cluster sites, Deerfield River Basin, northwestern Massachusetts, July 5-7, 1994-Continued. 
Table 1. Effects of varying hydraulic properties on the calibrated heads during the rise of river stage, Deerfield River Basin, northwestern Massachusetts, July 5, 1994

[Changes in simulated head: Head is greater than (+) or less than (-) calibrated model. $\mathrm{ft}$, foot; ft/d, foot per day]

\begin{tabular}{|c|c|c|c|c|c|c|c|c|}
\hline \multirow[b]{2}{*}{$\begin{array}{l}\text { Observation well cluster site } \\
\text { (see fig. 6) }\end{array}$} & \multicolumn{8}{|c|}{ Changes in simulated head (ft) with changes in: } \\
\hline & \multicolumn{2}{|c|}{$\begin{array}{l}\text { Vertical hydraulic } \\
\text { conductivity of } \\
\text { riverbed }(\mathrm{ft} / \mathrm{d})\end{array}$} & \multicolumn{2}{|c|}{ Anisotropy } & \multicolumn{2}{|c|}{ Specific yield } & \multicolumn{2}{|c|}{ Storage coefficient } \\
\hline \multicolumn{9}{|l|}{ Riverbank cluster } \\
\hline 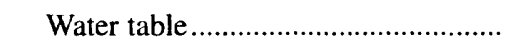 & -0.58 & +0.16 & -0.01 & +0.02 & +0.07 & -0.09 & -0.01 & +0.01 \\
\hline Deep & -.23 & +.07 & +.28 & -.19 & +.12 & -.10 & -.09 & +.02 \\
\hline \multicolumn{9}{|l|}{ Far cluster } \\
\hline 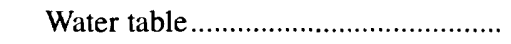 & -.30 & +.08 & +.05 & -.03 & +.17 & -.19 & -.03 & 0 \\
\hline 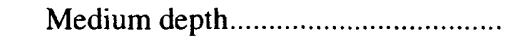 & -.30 & +.08 & +.04 & -.08 & +.14 & -.15 & -.04 & +.01 \\
\hline
\end{tabular}

3. Storage in the unconfined layer: Halving and doubling the specific yield, from 0.040 to 0.020 and 0.080 resulted in major changes on all heads, especially in the observation wells farthest from the river. Decreasing the specific yield to 0.020 resulted in a corresponding decrease in river leakage of 28 percent, and increasing the specific yield to 0.080 resulted in a corresponding increase in river leakage of 38 percent.

4. Storage in the confined layers: Varying the storage of the confined layers by an order of magnitude from 0.0002 to 0.002 and 0.00002 caused little change in the heads except some variation in the deep observation wells. Changing the storage of the confined layers also caused little variation in river leakage; decreasing storage to 0.00002 decreased river leakage by 1 percent and increasing storage to 0.002 increased river leakage by 4 percent.

Storage determined by model calibration for the unconfined layer, 0.040 , is at the low end of a reported range in values for unconsolidated sediments (Freeze and Cherry, 1979). Hydraulic diffusivity was calculated directly from the river-stage and ground-water-level fluctuations using an analytical method described by Ferris (1963) to check the validity of this storage value determined from the numerical analysis. The analytical approach, however, makes several simplifying assumptions compared to the numerical approach such as one-dimensional groundwater flow and an isotropic, homogenous aquifer. The analytical method results in a hydraulic diffusivity of $177,000 \mathrm{ft}^{2} / \mathrm{d}$. A low storage value of 0.038 results from dividing the transmissivity of the site determined from the lithologic logs by the hydraulic diffusivity determined from the analytical method. The low storage value determined for the site could be due to one or a combination of factors. One explanation is that layer 1 contains many cobbles and boulders, solid masses with no pore space available for water to drain from or fill, which reduces the overall potential storage of this layer. A second explanation is that, because the water table is continuously rising or declining, water does not have time to completely drain from or enter pore spaces. Water draining or entering the pore spaces at the water table is time dependent and gradually approaches its maximum value (Bear, 1979).

According to Lohman and others (1972), the definition of specific yield implies the maximum value. A third possible explanation is that storage at small values of time following abrupt changes in river stage is a result of the compression and expansion of the water and the stratified drift, even in the unconfined layer, and then, at large values of time, storage is due predominately to specific yield (Neuman, 1981). Neuman describes the stream-aquifer interaction using concepts of delayed drainage developed from unconfined flow to a well (Neuman, 1972). The finite-difference model cannot simulate the ground-water system using a storage value that varies with time; therefore the storage value determined by the model calibration would lie between the unconfined and confined storage. 


\section{Recharge to a Stratified-Drift Valley Bordered by Upland Till and Bedrock in the Berkshire Hills}

Recharge to a stratified-drift valley is defined as water that is added to the saturated zone. An increased understanding of recharge and its seasonal variability is important for water-resource planners because the water available from the stratified drift is dependent on how much water enters, or recharges the stratified drift. Recharge to the stratified drift is first described by determining the sources and quantities of water available for recharge. The effects of seasonal variation in recharge on ground-water levels and flow are then determined using hydrographs and water-table maps. Finally, a ground-water-flow model was used to refine concepts of recharge processes by assessing the effect of water available for recharge estimates and resulting simulated heads to actual ground-water data.

\section{Description of Recharge Study Area}

The recharge study area is in the narrow valley of Clesson Brook, in a rural area of the town of Buckland (figs. 1 and 8). The data-collection network is in the central section of the valley. The boundaries of the study area were extended up and down valley to natural boundaries of the hydrologic system for two reasons (1) rates and quantities of recharge could be determined more accurately, and (2) a large area minimizes the effect of model boundary conditions on simulated heads near the observation wells.

Sediment samples from the central section of the study area indicate that the valley is underlain by stratified drift primarily of fine-grained deposits consisting of fine sand and silt; a coarse layer of varying thickness, which consists primarily of sand and gravel, also underlies the valley (fig. 9). The stratified drift is about $65 \mathrm{ft}$ thick in the center of the valley and becomes thinner toward the valley and upland contacts. Grain-size distributions were determined from nine samples in the fine-grained deposits and from three samples in the coarse layer. Hydraulic conductivity, determined from these grain-size distributions using a method described by Krumbein and Monk (1943), ranged from 0.1 to $4 \mathrm{ft} / \mathrm{d}$ in the fine-grained deposits and from 48 to $100 \mathrm{ft} / \mathrm{d}$ in the coarse layer.
The stratified-drift valley is bounded by Clesson Brook, the main valley stream, and by tillcovered metamorphic bedrock that rises to $680 \mathrm{ft}$ above the valley floor. Several deeply incised channels, in some places exposing bedrock, drain the uplands. These upland channels were not apparent from U.S. Geological Survey topographical maps, but were determined from field observations and aerial photography. One of the upland channels, Wilder Brook, crosses the valley and drains into Clesson Brook; another upland channel drains into the northeast part of the valley and crosses to Clesson Brook at the base of the valley wall.

The data-collection network included seven observation wells and a continuous streamflowgaging station. Water levels in the observation wells, which are screened at or near the water table, were measured from October 1993 to December 1994 either manually or by a continuous data-recorder. One well is near the valley and upland contact, two wells were installed adjacent to Wilder Brook, and four wells were installed near the center of the valley. The streamflow-gaging station was established on Wilder Brook near the valley and upland contact; continuous streamflow data were collected from December 1993 to December 1994, and observations of flow were made in October and November 1993.

\section{Sources and Water Available for Recharge}

Water from three different sources recharges the stratified drift. One source is direct infiltration of precipitation that falls on the approximately $0.12 \mathrm{mi}^{2}$ of stratified drift. The amount of water available for recharge from this source on a monthly basis was determined using a water-balance method described by Lyford and Cohen (1988). The monthly amounts of water available from October 1993 to December 1994 are shown in table 2; water available from this source varies monthly depending on precipitation, snowcover, evapotranspiration, and soil moisture. Results of the water-balance method indicate that water is available for recharge from November through May; most of the water is available during late autumn after the soil moisture deficit of the previous summer has been satisfied and during the snowmelt of early spring. Less water is available during the winter freeze and none is available during the growing season when evapotranspiration is high. 


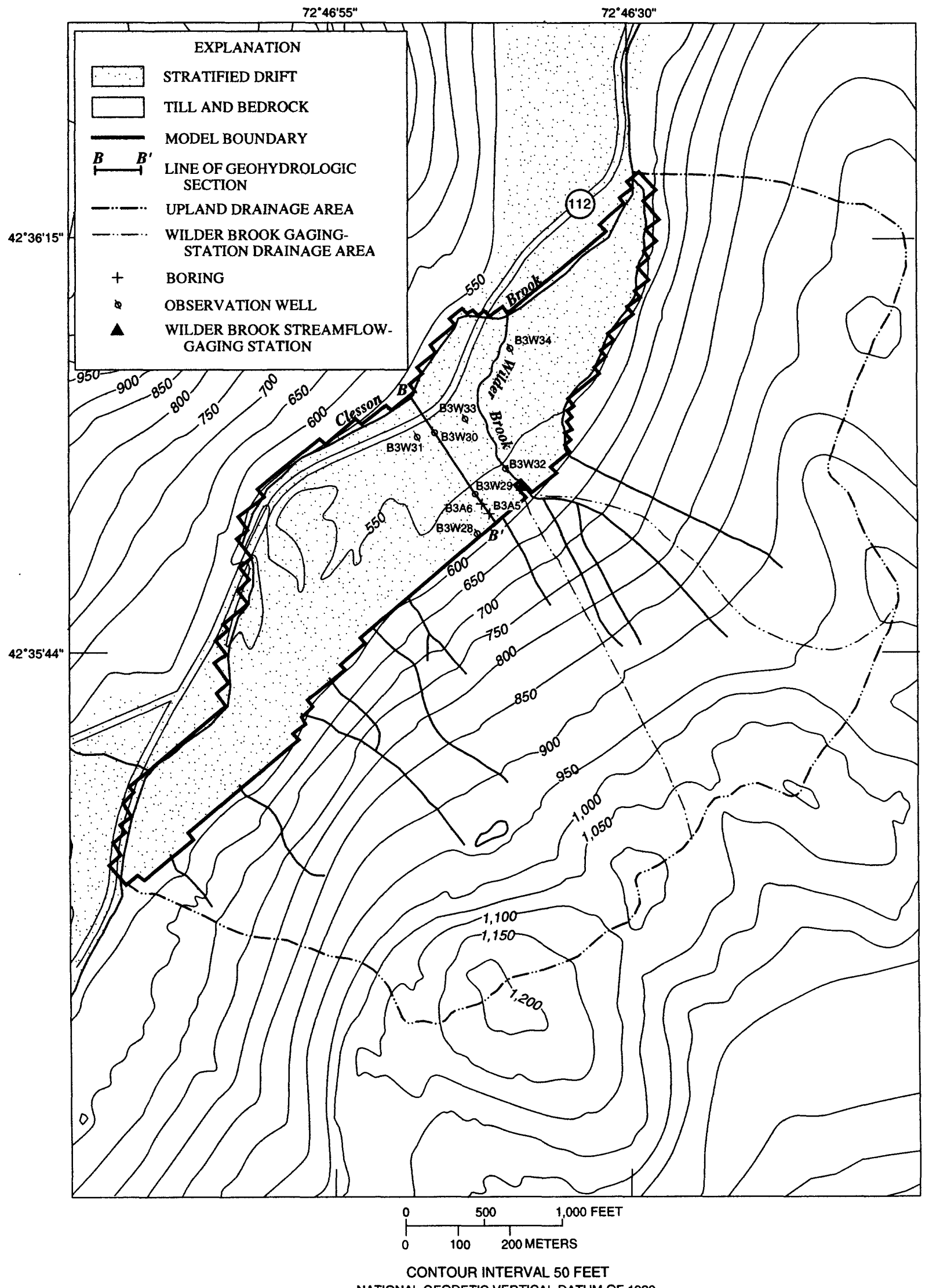

NATIONAL GEODETIC VERTICAL DATUM OF 1929

Figure 8. Location of recharge study area and principal geographic features and data-collection network, Deerfield River Basin, northwestern Massachusetts. (See figure 1 for location of study site B.) 


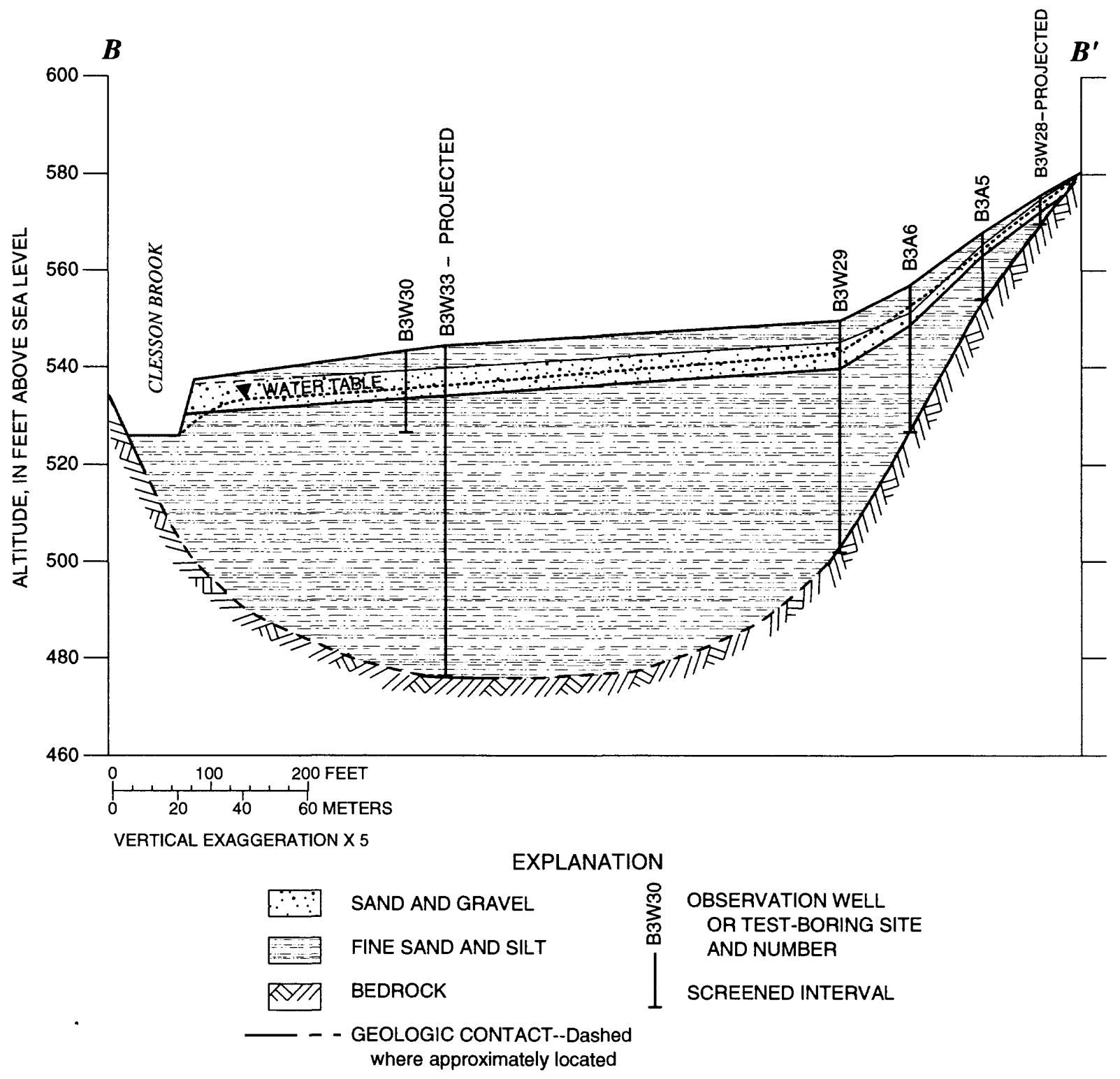

Figure 9. Geohydrologic section of recharge study area, Deerfield River Basin, northwestern Massachusetts. (Line of geohydrologic section shown in figure 8.)

From October 1993 to December 1994, a total of 56.10 in. fell on the valley but only 28.43 in. were actually available to recharge the stratified drift.

A second source of recharge to the stratified drift is Wilder Brook, a small intermittent stream that drains about $0.07 \mathrm{mi}^{2}$ of upland and crosses the valley to Clesson Brook. A graph of discharge at the continuousstreamflow-gaging station at Wilder Brook, installed near the valley and upland contact, shows seasonal trends in upland flow (fig. 10B). Streamflow is continuous from late autumn until spring, whereas during the growing season, Wilder Brook flows only after intense precipitation events. Because the stream channel in the valley is usually above the water table, water infiltrates through the streambed to the saturated zone. When flow occurs at the gage, it usually is completely lost to the stratified drift before reaching Clesson Brook, except after intense precipitation events and during the spring snowmelt.

Streamflow at the gaging station (at the valley and upland contact) and observations of where the streamflow ended were used to determine loss per unit 
Table 2. Water-balance computation of water available for direct infiltration, Deerfield River Basin, northwestern Massachusetts

[Precipitation: Data from New England Power Company, $2.5 \mathrm{mi}$ northeast of recharge study area. Snow storage or melt: Estimated from climatological data from New England Power Company and field observations. Evapotranspiration: Annual evapotranspiration determined by subtracting runoff data (gaging station Green River near Colrain 01170100) from precipitation for water year 1994 (46.81 in.-25.64 in. =21.17 in.). Monthly distribution of evapotranspiration estimated from percentage of pan evaporation at Hartford, Conn. Accumulated soil moisture deficit: Value for October 1993 is the soil moisture deficit due to the preceding dry summer carried over from September 1993. $\mathrm{ft}^{3}$, cubic foot; in., inch; in/mo, inch per month; mi ${ }^{2}$, square mile]

\begin{tabular}{|c|c|c|c|c|c|c|c|}
\hline \multirow[b]{2}{*}{ Month } & \multirow[b]{2}{*}{$\begin{array}{l}\text { Precipitation } \\
\quad \text { (in.) }\end{array}$} & \multirow[b]{2}{*}{$\begin{array}{c}\text { Snow } \\
\text { storage }(-) \text { or } \\
\text { melt (+) }\end{array}$} & \multirow[b]{2}{*}{$\begin{array}{l}\text { Evapotran- } \\
\text { spiration }\end{array}$} & \multirow[b]{2}{*}{$\begin{array}{c}\text { Soil moisture } \\
\text { depletion }(+) \\
\text { addition }(-)\end{array}$} & \multirow[b]{2}{*}{$\begin{array}{c}\text { Accumulated } \\
\text { soil moisture } \\
\text { deficit }\end{array}$} & \multicolumn{2}{|c|}{ Water available } \\
\hline & & & & & & $\begin{array}{c}\text { For direct } \\
\text { infiltration } \\
\text { (in/mo) }\end{array}$ & $\begin{array}{c}\text { On } 0.12 \mathrm{mi}^{2} \text { of } \\
\text { stratified drift } \\
\left(\mathrm{ft}^{3}\right)\end{array}$ \\
\hline \multicolumn{8}{|l|}{1993} \\
\hline October........ & 3.41 & -- & 1.65 & -1.76 & +3.09 & 0 & 0 \\
\hline November... & 5.32 & -- & -- & -3.09 & 0 & 2.23 & 621,700 \\
\hline December ... & 5.87 & -0.3 & -- & -- & -- & 5.57 & $1,553,000$ \\
\hline \multicolumn{8}{|l|}{1994} \\
\hline January ........ & 4.26 & -3.2 & -- & -- & -- & 1.06 & 295,500 \\
\hline February ..... & 2.33 & -1.7 & -- & -- & -- & .63 & 175,600 \\
\hline March ............... & 4.55 & +1.8 & -- & -- & -- & 6.35 & $1,770,000$ \\
\hline April ................ & 3.54 & +3.4 & 2.60 & -- & -- & 4.34 & $1,210,000$ \\
\hline 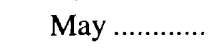 & 4.15 & -- & 3.43 & -. & -- & .72 & 200,700 \\
\hline 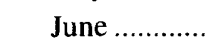 & 2.50 & -- & 3.70 & +1.20 & +1.20 & 0 & 0 \\
\hline July .................. & 1.76 & -- & 3.92 & +2.16 & +3.36 & 0 & 0 \\
\hline August ......... & 3.69 & -- & 3.54 & -.15 & +3.21 & 0 & 0 \\
\hline September.. & 5.43 & -- & 2.33 & -3.10 & +.11 & 0 & 0 \\
\hline October........ & 1.04 & -- & 1.65 & +.61 & +.72 & 0 & 0 \\
\hline November... & 3.95 & -.9 & -- & -.72 & 0 & 2.33 & 649,600 \\
\hline December... & 4.30 & +.9 & -- & -- & -- & 5.20 & $1,450,000$ \\
\hline
\end{tabular}

length of stream channel (fig. 11). A potential maximum infiltration rate of $0.18 \mathrm{ft}^{3} / \mathrm{s}$ is lost along the $1,000 \mathrm{ft}$ channel; this loss is similar to that determined in hydrologic studies of the first $1,000 \mathrm{ft}$ downstream from the upland and valley contact in New York (Randall, 1978) and in New Hampshire and Pennsylvania (Morrissey and others, 1988). Recharge from water loss along the channel was assumed to equal the maximum infiltration rate of $0.18 \mathrm{ft}^{3} / \mathrm{s}$ per $1,000 \mathrm{ft}$ when flow in Wilder Brook crossed the valley and discharged to Clesson Brook. Monthly amounts of water available to recharge the stratified drift from streamflow loss are shown in table 3. Similar to direct infiltration from precipitation, recharge from streamflow loss is available primarily during late autumn and during snowmelt in early spring. Another stream draining the uplands and crossing to Clesson Brook in the northeast section of the study area along the upland and valley contact was assumed not to contribute recharge because the sediments beneath the stream at this location probably are thin and not very permeable.

A third source of recharge to the stratified drift is ground-water inflow and surface-water runoff from about $0.21 \mathrm{mi}^{2}$ of adjacent uplands that are not drained by stream channels that cross the valley. Upland runoff has the potential to recharge the stratified drift at, or near, the valley and upland contact by lateral groundwater flow and by surface-water runoff from upland channels. Figure 8 shows seven channels draining the uplands between Wilder Brook and the upvalley boundary of the study area that end at the valley and upland contact. These upland channels, which flow after intense precipitation events during autumn and spring and during spring snowmelt, usually lose all flow at the valley and upland contact. These channels 

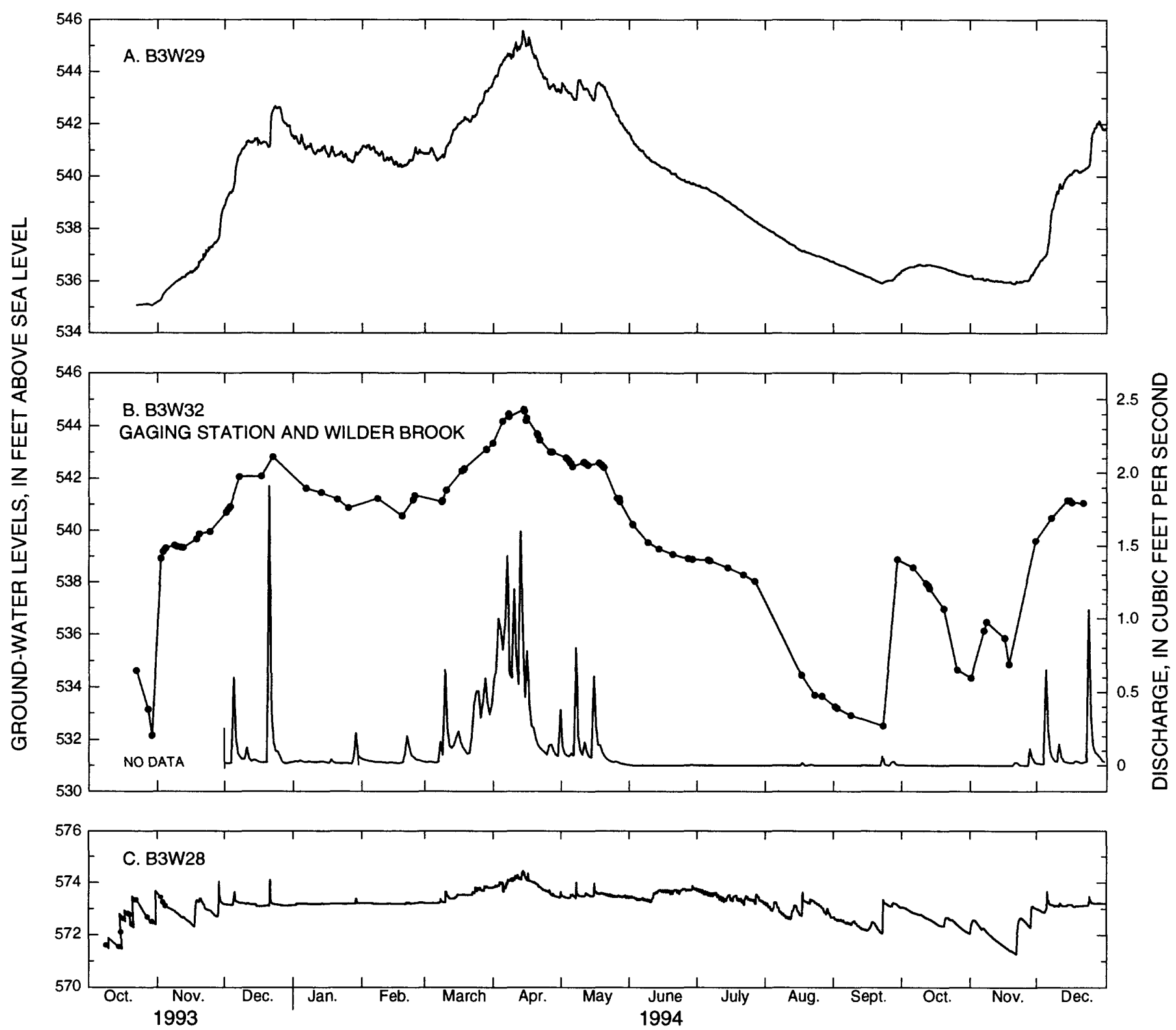

Figure 10. Ground-water levels in selected observation wells and discharge at Wilder Brook gaging station, Deerfield River Basin, northwestern Massachusetts, October 1993 to December 1994. A. B3W29, B. B3W32, C. B3W28.

lose more water at the valley and upland contact than Wilder Brook because flow from these channels fans out at the contact and infiltrates over a large surface area. For example, on March 22, 1995, measurements of flow in the upland channels just above the valley and upland contact were obtained with a Parshall flume. The maximum flow at one of these channels was $0.08 \mathrm{ft}^{3} / \mathrm{s}$, which was all lost close to the valley and upland contact, whereas the same quantity of flow at Wilder Brook gaging station would be lost about $450 \mathrm{ft}$ downstream from the contact (fig. 11). 


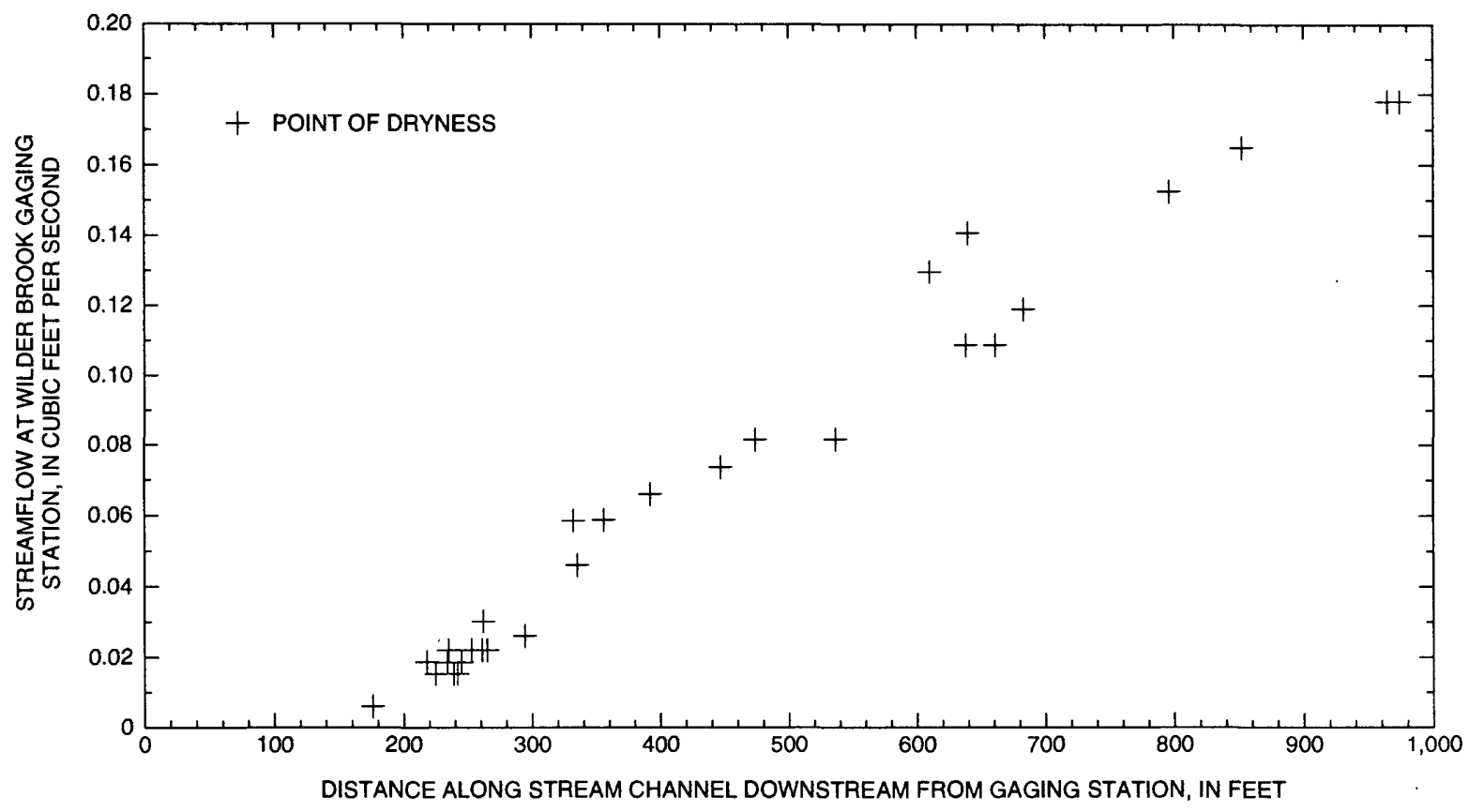

Figure 11. Stream infiltration along Wilder Brook, Deerfield River Basin, northwestern Massachusetts.

Table 3. Water available from streamflow loss from Wilder Brook and for ground-water and surface-water runoff from uplands, Deerfield River Basin, northwestern Massachusetts

$\left[\mathrm{ft}^{3}\right.$, cubic foot; $\left(\mathrm{ft}^{3} / \mathrm{s}\right) / \mathrm{mi}^{2}$, cubic foot per second per square mile; $\mathrm{mi}^{2}$, square mile]

\begin{tabular}{|c|c|c|c|}
\hline \multirow[t]{2}{*}{ Month } & \multirow{2}{*}{$\begin{array}{l}\text { Streamflow } \\
\text { loss from } \\
\text { Wilder Brook } \\
\left(\mathrm{ft}^{3}\right)\end{array}$} & \multicolumn{2}{|c|}{$\begin{array}{l}\text { Ground-water and surface- } \\
\text { water runoff from } 0.21 \mathrm{mi}^{2} \\
\text { uplands }\end{array}$} \\
\hline & & $\begin{array}{c}\text { Rate } \\
{\left[\left(\mathrm{ft}^{3} / \mathrm{s}\right) / \mathrm{mi}^{2}\right]}\end{array}$ & $\begin{array}{l}\text { Total } \\
\left(\mathrm{ft}^{3}\right)\end{array}$ \\
\hline \multicolumn{4}{|l|}{1993} \\
\hline October ............ & ${ }^{1} 1,100$ & 0.40 & 225,000 \\
\hline November...... & ${ }^{1} 41,500$ & 1.48 & 805,600 \\
\hline December ....... & 169,000 & 2.84 & $1,597,000$ \\
\hline \multicolumn{4}{|l|}{1994} \\
\hline January ........... & 83,020 & 1.12 & 630,000 \\
\hline February ......... & 96,290 & 1.07 & 543,600 \\
\hline March .............. & 334,800 & 2.90 & $1,631,000$ \\
\hline April .................. & 401,800 & 8.06 & $4,387,000$ \\
\hline 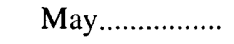 & 224,400 & 2.78 & $1,564,000$ \\
\hline June .................... & 1,815 & .74 & 402,800 \\
\hline 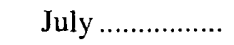 & 0 & .38 & 213,700 \\
\hline August ............. & 2,598 & .42 & 236,200 \\
\hline September...... & 10,370 & .51 & 277,600 \\
\hline October ............ & 1,038 & .36 & 202,500 \\
\hline November...... & 21,600 & .66 & 359,200 \\
\hline December ...... & 159,600 & 2.49 & $1,401,000$ \\
\hline
\end{tabular}

Direct measurements were not obtained to estimate monthly ground-water and surface-water runoff from the uplands. Monthly runoff rates were estimated using the discharge record from a continuous streamflow-gaging station on the Green River near Colrain (01170100), which drains a $41.4 \mathrm{mi}^{2}$ basin underlain by 97.6 percent till and bedrock. Runoff rates from Wilder Brook drainage area were not applied to the remaining upland drainage area because of the difficulty in accurately determining the size of Wilder Brook drainage area and because of possible underflow not measured at the gaging station. A monthly runoff rate per unit area, estimated from the Green River gaging station, was applied to the $0.21 \mathrm{mi}^{2}$ of uplands draining toward the valley; monthly rates and volumes are shown in table 3 . Recharge to the stratified drift from upland runoff is available every month of the year, but most is available during late autumn and the spring snowmelt.

Comparisons of the three different sources of water available for recharge to this stratified-drift valley indicate that on an annual basis, from October 1993 to September 1994,30 percent $\left(5,826,000 \mathrm{ft}^{3}\right)$ of the recharge is from direct infiltration of precipitation, 7 percent $\left(1,367,000 \mathrm{ft}^{3}\right)$ from streamflow loss, and 63 percent $\left(12,510,000 \mathrm{ft}^{3}\right)$ from upland runoff. Recharge derived from upland sources totaled 
70 percent of the recharge, indicating that the upland till and bedrock is the primary source of recharge to the valley. The percentage of recharge from upland sources falls within the range of values reported in studies of similar valley and upland settings in the Northeast (Morrissey and others, 1988). Morrissey and others (1988) concluded that the percentage of recharge derived from upland sources tends to increase with increasing upland topographic relief and with decreasing valley width.

The calculations of water available to recharge the stratified drift from three different sources probably overestimate actual recharge. During the peak of spring snowmelt, from late March through mid-April 1994, the water table rose to, or nearly to, the land surface throughout the valley and water drained through shallow channels and across surface depressions to Clesson Brook. After the snowmelt peak, the water table was at the land surface along some sections of the valley and upland contact and, after intense precipitation events, upland runoff would again flow across the valley and discharge to Clesson Brook. In addition, the estimate of water available from streamflow loss assumes that Wilder Brook is always losing along its entire length. During the spring snowmelt, the upper part of the channel is always losing water because of the relation of ground-water levels to channel-bed altitudes; however, the lower part of the channel is a gaining reach based on ground-water and channel-bed altitudes and discharge measurements.

\section{Seasonal Changes in Ground-Water Levels and Flow Directions}

Seasonal variations in recharge caused the altitude of the water table to fluctuate in the stratified drift. Hydrographs, shown in figure 10 , illustrate these fluctuations from October 1993 to December 1994.

Water levels in observation well B3W29 (fig. 10A) are typical of the hydrographs from observation wells in the valley (called valley wells) not adjacent to the valley and upland contact or to Wilder Brook. The hydrographs from the valley wells show a similar pattern probably because of the combined effects of recharge from all three sources and the narrowness of the valley. Ground-water levels rise in late autumn and early spring when most recharge occurs and recharge exceeds discharge; ground-water levels decline when less recharge is available during the winter freeze and during the growing season from May to October. The maximum altitude of the water table in 1994 for all valley wells was in April and the lowest in September; the annual water-level fluctuations ranged from 6.1 to $10.5 \mathrm{ft}$.

Effects of streamflow loss on adjacent groundwater levels is illustrated using hydrographs from observation well B3W32 and Wilder Brook gaging station (fig. 10B). Observation well B3W32, measured intermittently, is $110 \mathrm{ft}$ downstream from the continuous streamflow-gaging station. Water levels in observation well B3W32 fluctuate in a similar pattern as the valley wells during winter and spring when streamflow is continuous. In the autumn, however, when intense precipitation events caused Wilder Brook to flow, streamflow loss caused large fluctuations in adjacent ground-water levels. For example, streamflow loss caused abrupt 6.8- and 6.4-foot rises in groundwater levels in observation well B3W32 from October 29 to November 2, 1993, and from September 23 to September 28, 1994, respectively. In June, after Wilder Brook ceased to flow continuously, no appreciable change in the adjacent ground-water levels occurred, probably because some water draining from the uplands passed the gaging station as underflow. Less than 2 months later a sharp decline in the ground-water level indicated that contribution to recharge had largely ceased from the upland Wilder Brook drainage area.

The hydrograph from observation well B3W28, located on the hillside adjacent to the stratified drift and upland contact, is shown in figure $10 C$. Water levels respond rapidly to recharge events from upland runoff and from direct infiltration because of the proximity of the well to the contact and thinness of the unsaturated zone (unsaturated zone ranges from 1.4 to $4.6 \mathrm{ft}$ ). Water levels in observation well B3W28 had a smaller total range of fluctuation, $3.2 \mathrm{ft}$, than other observation wells, and the lowest water level occurred in November, not September. In addition, water levels in this well did not decline in winter, which may indicate a small constant ground-water recharge from the uplands. The difference in water levels on the hillslope compared to other observation wells probably is due to effects of upland recharge and the complexity of the hillslope topography.

The altitude and configuration of the water table along the lower part of Wilder Brook for four dates in 1994 are shown in figure 12. The water-table maps, representative of only a small section of the valley, are drawn on the basis of water levels obtained from five 


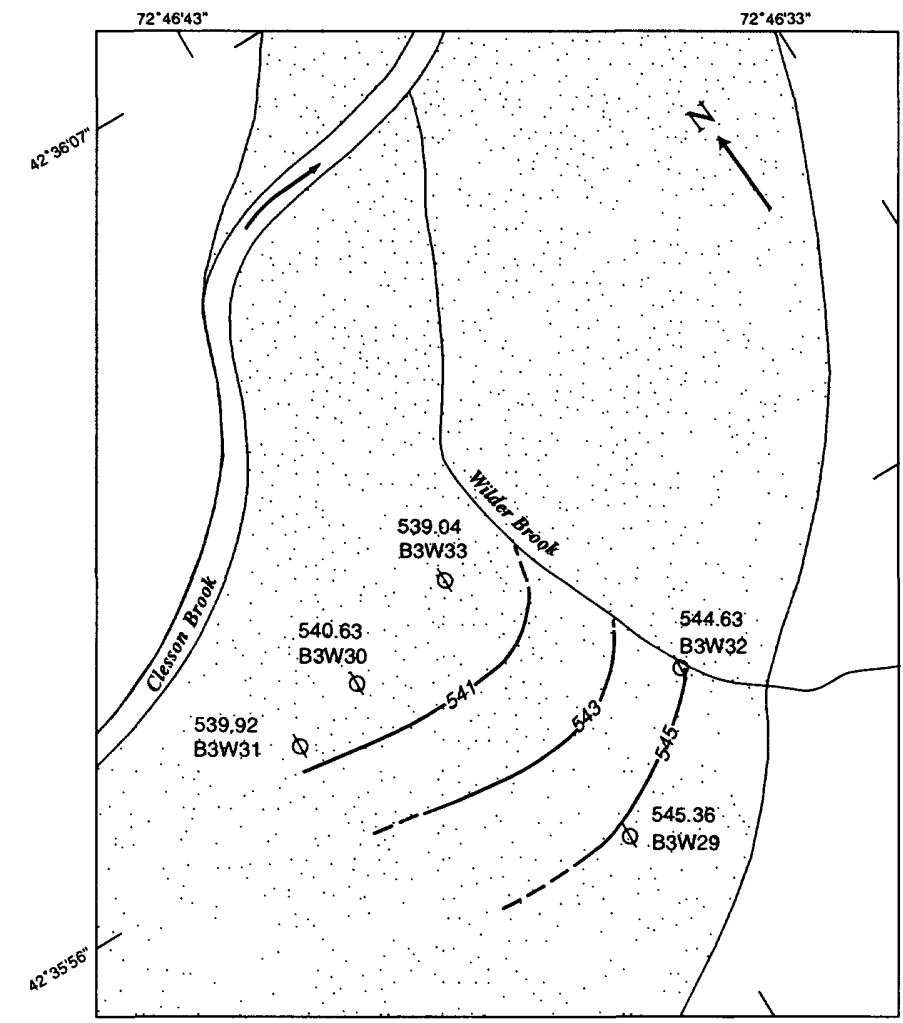

A. April 14,1994

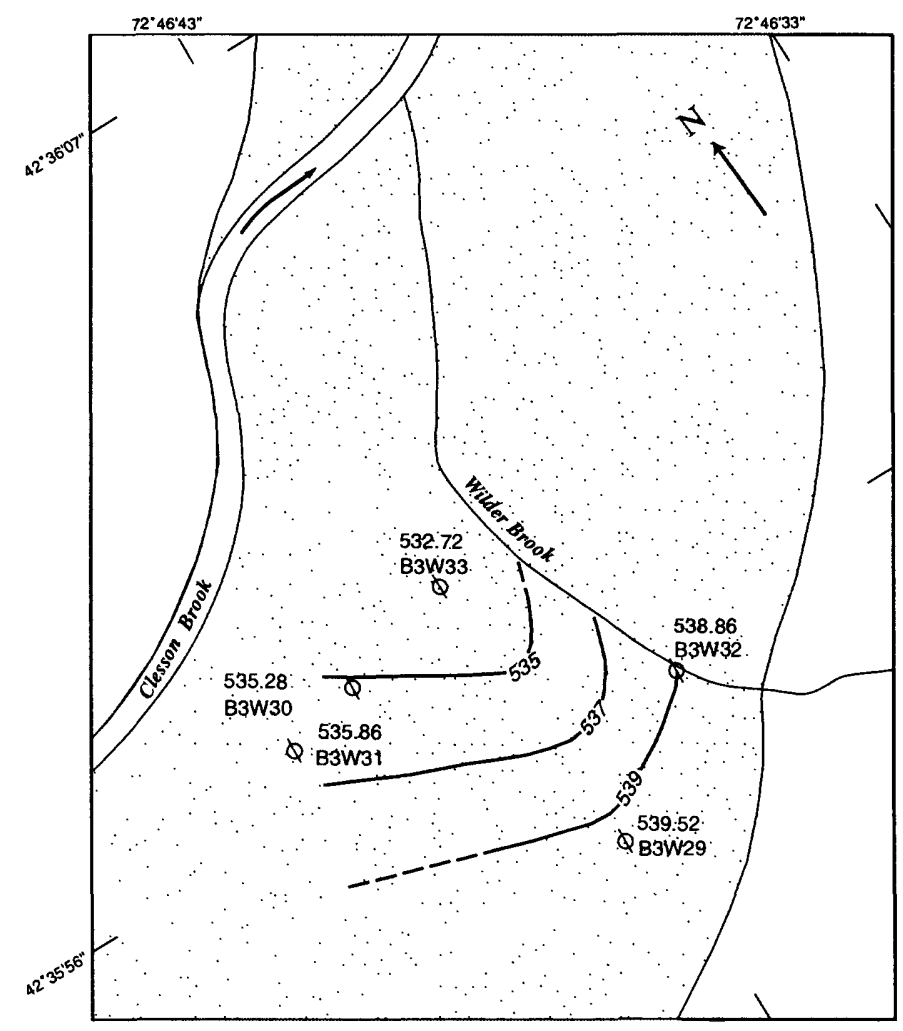

B. July 6,1994

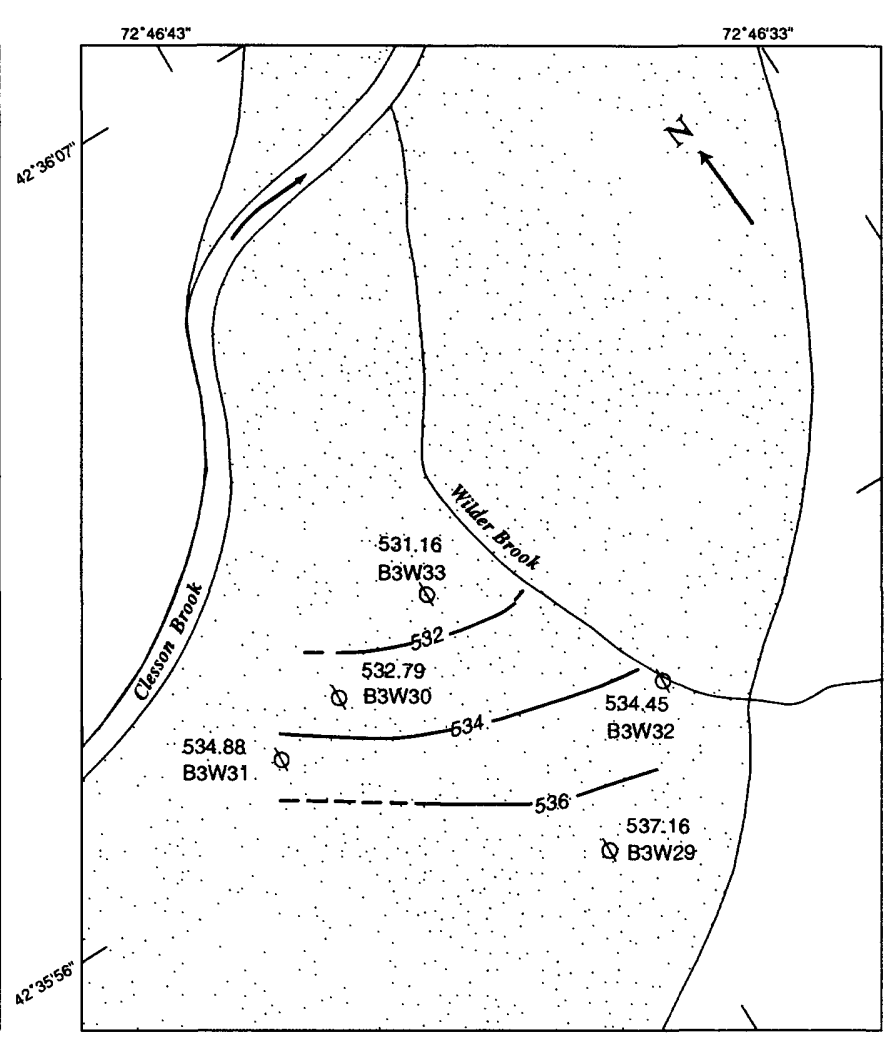

C. August 17,1994

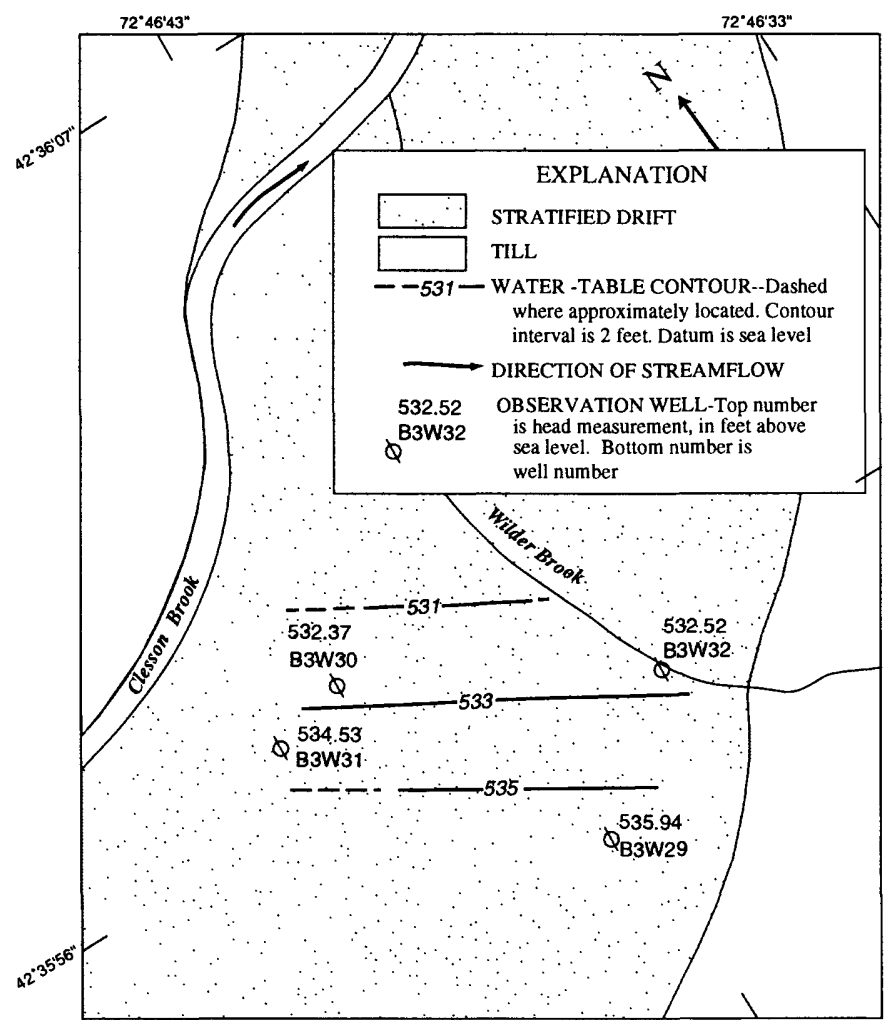

D. September 23,1994

Figure 12. Altitude and configuration of the water table for April 14, July 6, August 17, and September 23, 1994, Deerfield River Basin, northwestern Massachusetts. 
observation wells. The water-table map for April, during the peak of the snowmelt, represents the highest water level, and the map for September, near the end of the growing season, represents the lowest water level.

The water-table maps indicate changes in the general direction of ground-water flow due to the seasonal distribution of recharge. The water-table configuration for April and September represents the two extremes in the direction of ground-water flow, while the maps for July and August show a gradual change between the two extremes. In April, the direction of ground-water flow is more nearly perpendicular to the valley axis than it is for the other months, flowing in a shorter path from the valley and upland contact toward Clesson Brook. In September, the direction of ground-water flow is nearly parallel to the valley axis, flowing down valley. Seasonal changes in groundwater flow direction probably are due to the varying quantities of water flowing through the stratified drift and the varying quantities of upland recharge.

The water-table contours bend downstream near Wilder Brook in the April and July water-table maps because of streamflow loss. The bend in the water-table contours is evident even after Wilder Brook has stopped flowing, indicating, as was mentioned in the discussion of the hydrograph from observation well B3W32, that some underflow may not be measured at the streamflow-gaging station. The August and September water-table maps show little or no bend in the water-table contours near Wilder Brook, indicating that recharge from the upland drainage area has virtually ceased or no longer affects the water table.

\section{Recharge Determined from Simulation of Ground-Water Flow}

An evaluation of the hydrologic system was made using a finite-difference model (McDonald and Harbaugh, 1988) as a tool to increase understanding of the ground-water system and recharge processes in the stratified-drift valley. The study area was simulated to determine if the estimates of water available for recharge provide reasonable estimates of actual recharge based on measured ground-water-level fluctuations, especially in March and April when observations in the valley indicate that more water is available for recharge than actually recharges the stratified drift. In addition, because the water-table contours represent a localized, complex area adjacent to the uplands and a losing stream, a larger more extensive simulated area was needed to confirm that the general direction of ground-water flow changes seasonally throughout the valley. The model constructed is a simplistic representation of the valley and is not a fully calibrated and detailed model intended for any future predictions.

\section{Description of Model}

The two-layer, finite-difference model used to simulate ground-water flow in the stratified drift is shown in figure 13. The grid consists of 71 rows and 29 columns; the grid has finer spacing, 50 by $50 \mathrm{ft}$ cells in the central part of the valley where groundwater levels are known, and coarser spacing, 50 by $100 \mathrm{ft}$ cells, that extend up and down the valley. The top boundary of the stratified drift is the water table and is computed by the model. The geologic contact between the permeable stratified drift and the relatively impermeable till and bedrock represents the bottom and most of the sides of the model. Clesson Brook forms another boundary and is simulated by constant heads equivalent to surface-water altitudes determined from a site survey and interpolation between topographic contours. Layer 1 represents coarse and fine-grained material and contains Clesson Brook; layer 2 represents the remaining fine-grained material beneath layer 1 .

Recharge to the stratified drift from the three different sources was applied at monthly rates. Each month represents a stress period and is subdivided into six time steps. Recharge from direct infiltration was distributed uniformly over the stratified drift. Infiltration from Wilder Brook was distributed based on field measurements and was simulated by specified fluxes. All ground-water and surface-water runoff from the uplands was evenly distributed at cells in the top layer adjacent to the uplands and simulated by specified fluxes. All other cells adjacent to the till and bedrock contact were no-flow boundaries. 


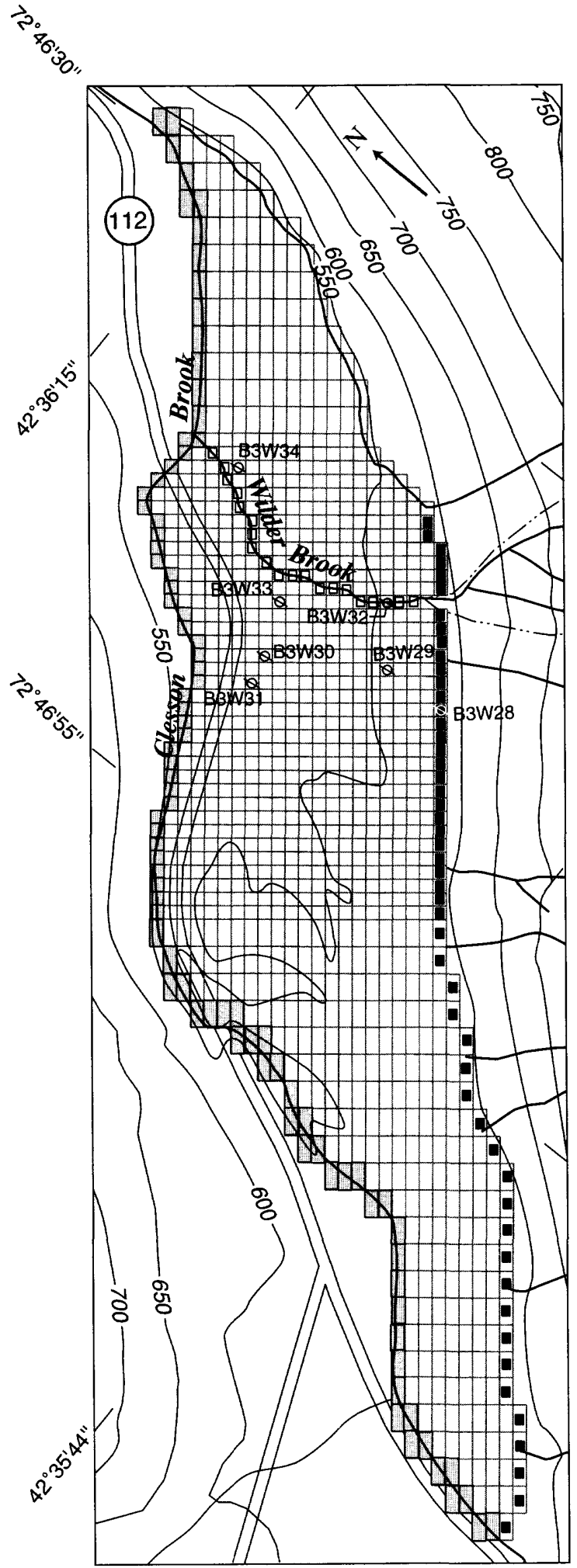

Figure 13. Grid and cell types for the finite-difference model of the ground-water system, Deerfield River Basin, northwestern Massachusetts.
EXPLANATION

\section{- CLESSON BROOK-CONSTANT HEAD CELLS}

- UPLAND RECHARGE-SPECIFIED FLUX CELLS

口 WILDER BROOK-SPECIFIED FLUX CELLS

$\underset{Q}{B 334}$ OBSERVATION WELL AND NUMBER

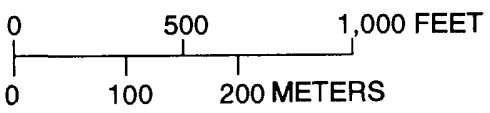

CONTOUR INTERVAL 100 FEET NATIONAL GEODETIC VERTICAL DATUM OF 1929

Ground-water hydrographs show that water levels in the early autumn of 1994 nearly return to the previous year's level, indicating little change in annual water storage. Initial conditions for each new set of model parameters were established by conducting several October through September simulations using the monthly estimates of water available for recharge as input. Heads at the end of each model run were used as starting heads for the next simulation until negligible difference in heads from autumn to autumn occurred. Recharge and ground-water-flow analyses are based on a simulation of 15 months, October 1993 to December 1994.

A general calibration of the model was made by varying hydraulic conductivity and specific yield in layer 1 and then comparing simulated and measured heads at observation wells B3W29 and B3W 33 . The other observation wells were not used in calibration because (1) model construction was too simplistic to simulate the hillside topography, (2) more stress periods in the autumn were needed to simulate abrupt changes in ground-water levels adjacent to Wilder Brook due to streamflow loss, and (3) Clesson Brook was simulated using 50 -foot-wide constant-head cells, which caused unrealistic low heads in nearby cells. A transmissivity value of $44 \mathrm{ft}^{2} / \mathrm{d}$ was used for layer 2 , based on hydraulic conductivity of $1 \mathrm{ft} / \mathrm{d}$ and a saturated thickness of $44 \mathrm{ft}$. Transmissivity was held constant through all simulations because little flow is transported through the fine-grained layer 2 compared 
to layer 1 and the simulations were not sensitive to layer 2 transmissivity. Calculated values of water available for recharge were used as the model-inputted recharge rates and were not varied during model calibration. Heads from October through March, the first seven stress periods before the peak of the snowmelt, were used for model calibration because field observations indicated water available for recharge may exceed actual recharge during the spring.

Final values of $50 \mathrm{ft} / \mathrm{d}$ and 0.2 for hydraulic conductivity and specific yield, respectively, provided the best match between measured and simulated heads. Simulated heads declined with increasing hydraulic conductivity and rose with decreasing hydraulic conductivity throughout the modeled area. The range in water-level fluctuation decreased with increasing specific yield and resulted in a shallower recession; decreasing specific yield caused the opposite effect.

\section{Results of Simulation}

Results of simulated heads using the monthly water available for recharge estimates from the three different recharge sources as model input were compared to the continuous hydrograph from observation well B3W29 from October 1993 to December 1994 (fig. 14). From October to March, the months used to calibrate the model, simulated and measured heads compare favorably. In April, however, during the spring runoff, simulated head overestimates measured head by $6 \mathrm{ft}$, which is above land surface. The peak in simulated head is delayed by 15 days because most of the recharge occurred in the first 15 days of April but the model stress period is for the full month. A shorter stress period than was used in the model would be required to more accurately reproduce the measured heads. In addition, the simulated heads in the spring and summer recession are higher than the measured heads. A comparison between simulated and measured heads indicates monthly water available for recharge is greater than actual recharge during the spring runoff and is consistent with field observations from the last week of March through mid-April when surface runoff was observed.

On the basis of observations of surface runoff during March and April, recharge values inputted to the model were reduced. Figure 14 shows the results of simulated heads when total recharge for March and April are 10 and 60 percent less, respectively, than original recharge estimates. Simulated and measured heads are similar until the spring and summer recession when simulated heads are still higher than measured heads; in the simulation, ground water evidently is not discharging from the stratified drift as quickly as in the actual system.

Another simulation of the study area was made using drains to more accurately represent conditions during the spring snowmelt by channelling water out of the modeled area when heads rise above land surface. Wilder Brook, other minor channels, and major surface depressions were simulated using drains. Figure 14 shows the simulated heads when drains were used. Observations at the site indicate that during the peak of the snowmelt most of the cells representing the stratified drift could be either rejecting recharge or discharging water, so that every cell in the model would need to be simulated using a drain in order to accurately simulate the stratified-drift valley. A method currently being developed, called variable recharge, allows recharge to an individual cell to occur only if the simulated head is lower than the land surface. This method also can be used to simulate discharge from each cell if simulated head is above land surface (Angelo Kontis, U.S. Geological Survey, written commun., 1994).

The altitude and configuration of the water table, simulated by the model for the whole valley, are shown in figure 15. The water-table maps for April represent the highest water levels and the map for September represents the lowest water levels. The maps shown in figure $15 A$ and $15 B$ are results from the simulation with recharge in March and April reduced by 10 and 60 percent, respectively. The map shown in figure $15 C$, also reflecting conditions in April, shows the water-table contours when Wilder Brook, channels, and major surface depressions were simulated using drains. Even though the water-table altitude is higher than actual conditions for the simulation using the drains, the map shows the complexity of the contours during peak recharge in spring; however, the general flow direction is similar to that in figure $15 A$. 


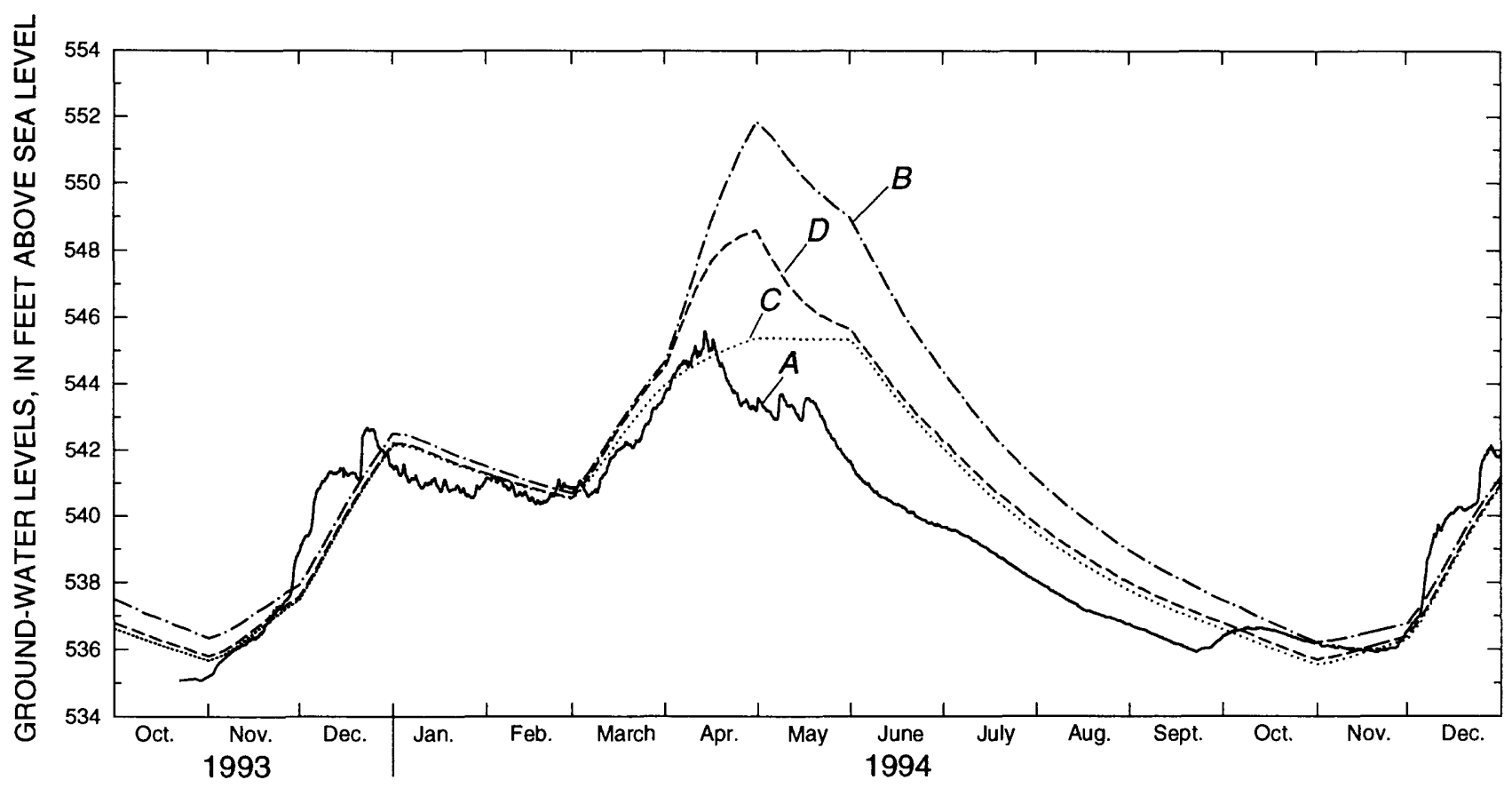

Figure 14. Comparison of measured heads in observation well B3W29 $(A)$ versus simulated heads using $(B)$ all water available for recharge, $(C)$ all water available for recharge except for March (10 percent less) and April (60 percent less), and $(D)$ all water available for recharge and drains, Deerfield River Basin, northwestern Massachusetts, October 1993 to December 1994.

The simulated water-table maps indicate seasonal changes in direction of ground-water flow that are similar to the more localized water-table maps. The principal direction of ground-water flow in April is across the valley from the valley and upland contact toward Clesson Brook. In September, the principal direction of ground-water flow has a stronger down valley component of flow than in April. Near the lower part of the valley, ground-water flow is down valley in both seasons because there is no upland runoff contribution.

Results of the recharge study indicate that estimates of the water available for recharge generally agree with actual recharge except during spring snowmelt and during intense precipitation events when water available for recharge is greater than actual recharge. Simulation of the ground-water system indicates that on an annual basis from October 1993 to September 1994, 31 percent $\left(4,924,000 \mathrm{ft}^{3}\right)$ of the recharge is from direct infiltration on $0.12 \mathrm{mi}^{2}$ of stratified drift, 7 percent $\left(1,092,000 \mathrm{ft}^{3}\right)$ is from streamflow loss from a brook that drains $0.07 \mathrm{mi}^{2}$ of uplands, and 62 percent $\left(9,718,000 \mathrm{ft}^{3}\right)$ is from ground-water and surface-water runoff from $0.21 \mathrm{mi}^{2}$ of uplands. By decreasing the water available for recharge estimates by 10 percent in March and 60 percent in April, the actual recharge to the valley on an annual basis was 20 percent less than original estimates. Computations of water available for recharge are useful for estimating actual recharge when the water table is below the land surface, which is generally the case throughout the year in most areas underlain primarily by coarsegrained stratified drift. However, in narrow stratifieddrift valleys consisting of thick fine-grained deposits and bounded by a large contributing upland area, the water table may, at times, rise to the land surface, thereby limiting recharge. 


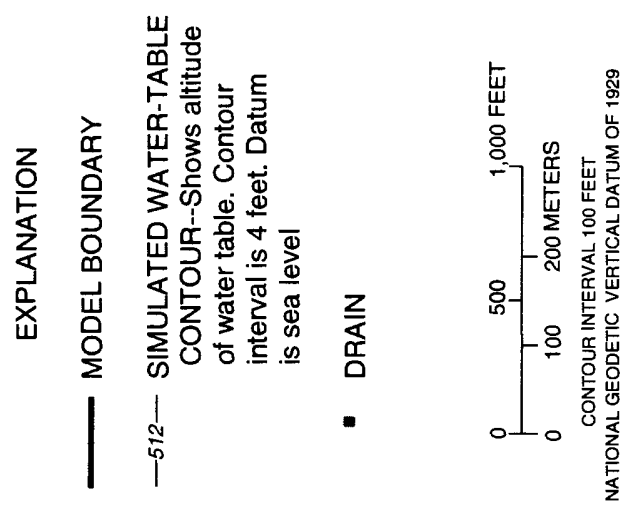

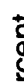
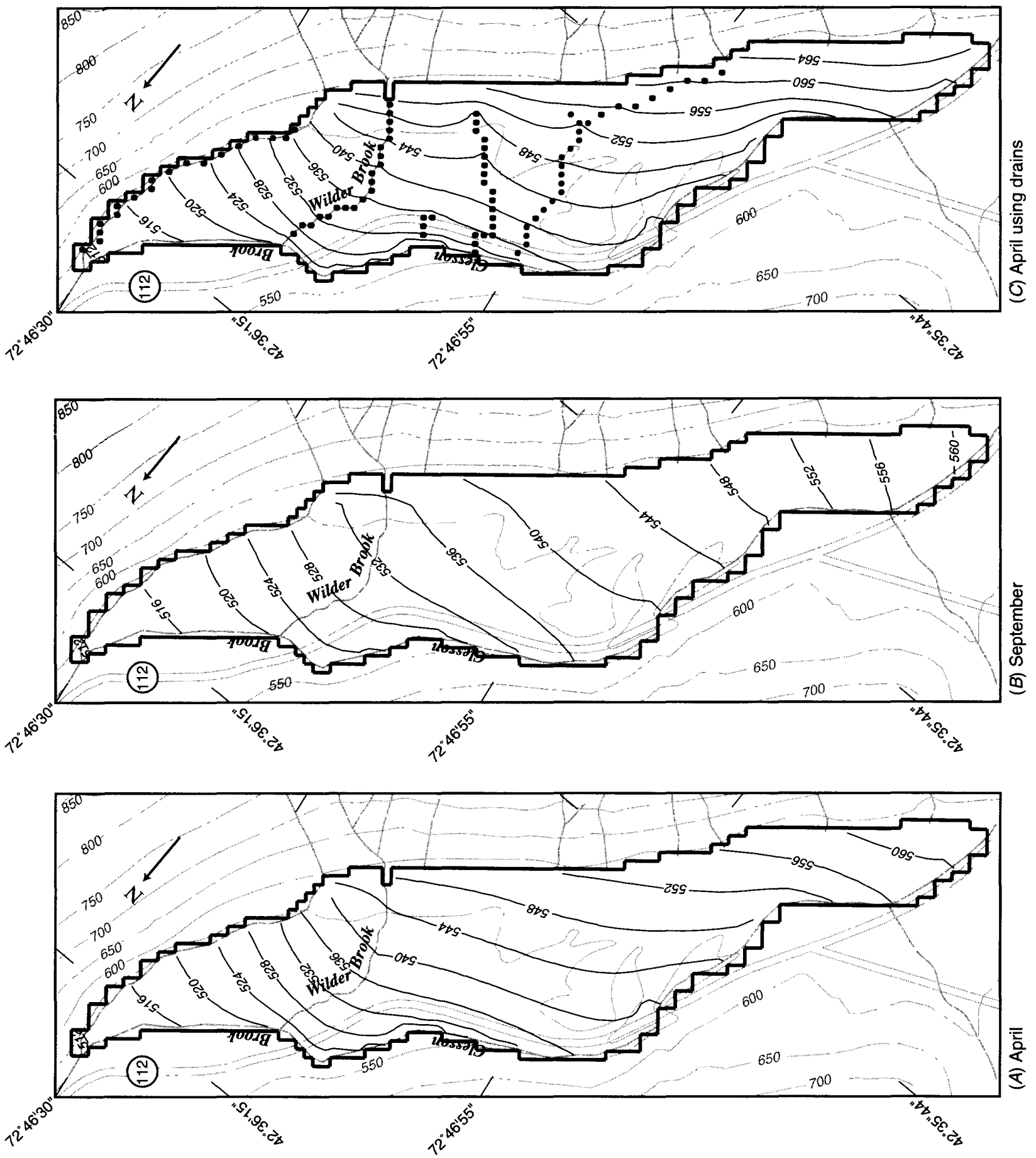


\section{STREAMFLOW}

Streamflow in the regulated Deerfield River was investigated by comparing streamflows in the regulated river to streamflows in the unregulated tributaries using flow-duration curves. Streamflows during periods of low flow from sites distributed throughout the basin were investigated using flow-duration analysis and seepage measurements.

\section{Comparison Between Streamflow in the Deerfield River and Selected Tributaries}

Because of increased uses of the Deerfield River for multiple purposes, water planners need more information on how current dam regulation affects the natural flow of the river as a first step in balancing environmental and recreational needs with hydroelectric-power generation requirements. Flow data from three continuous streamflow-gaging stations on the Deerfield River were compared to data from three continuous streamflow-gaging stations on unregulated tributaries in three geologically similar basins to determine how flows in the Deerfield River are affected by dam regulation. Flows on the regulated Deerfield River and the unregulated tributaries were compared on the basis of flow-duration curves, which indicate the percentage of time that flow in a stream is equaled or exceeded for a given period of record. The flow-duration curves were constructed using two sets of data-daily mean discharges and instantaneous discharges-because the curves based on daily mean flows may not reflect the extent of dam regulation. Because the continuous streamflow-gaging stations drain basins of similar geology, the shape of the flowduration curves should be similar if all six gaging stations drained unregulated basins. Station descriptions for all six stations that were used to compare streamflows in the regulated Deerfield River to unregulated tributaries are listed in table 4 and locations of the continuous gaging stations are shown in figure 16 . The relation of the continuous gaging stations on the Deerfield River to the dams are shown in figure 2.

Flow-duration curves for the six gaging stations constructed using daily mean discharges and a common period of the three most recent years of record available, water years $1992-1994^{1}$, are shown in figure $17 A$. In general, the shape of the flow-duration curves from the regulated stations is similar to those for the unregulated stations if daily mean discharges are used to construct the curves because the average of the high and low storage releases from the dams on a daily basis are usually nearly equivalent to the natural daily mean discharge.

\footnotetext{
${ }^{1} \mathrm{~A}$ water year is the 12 -month period beginning October 1 and ending September 30 . It is designated by the calendar year in which it ends.
}

Table 4. Description of streamflow-gaging stations, Deerfield River Basin, northwestern Massachusetts

[USGS station No.: Locations shown in figure 16. Latitude and longitude are given in degrees, minutes, seconds. Stratified-drift areas were measured by geographic information systems technology. USGS, U.S. Geological Survey; $\mathrm{mi}^{2}$, square mile; --, not computed]

\begin{tabular}{|c|c|c|c|c|c|c|}
\hline $\begin{array}{c}\text { USGS } \\
\text { Station No. }\end{array}$ & Station name & $\begin{array}{l}\text { Latitude } \\
\bullet, ",\end{array}$ & $\begin{array}{l}\text { Longitude } \\
., "\end{array}$ & Period of record & $\begin{array}{c}\text { Drainage } \\
\text { area } \\
\left(\mathbf{m i}^{\mathbf{2}}\right)\end{array}$ & $\begin{array}{l}\text { Stratified- } \\
\text { drift area } \\
\text { (percent) }\end{array}$ \\
\hline \multicolumn{7}{|c|}{ Streamflow-gaging stations on the unregulated tributaries to the Deerfield River } \\
\hline 01169000 & North River at Shattuckville & 423818 & 724332 & 1939 to present & 89.0 & 6.08 \\
\hline 01169900 & South River near Conway & 423231 & 724139 & 1966 to present & 24.1 & 13.2 \\
\hline 01170100 & Green River near Colrain & 424212 & 724016 & 1967 to present & 41.4 & 2.42 \\
\hline 01168151 & Deerfield River near Rowe & 424057 & 725837 & 1974 to present & 254 & -. \\
\hline 01168500 & Deerfield River at Charlemont & 423733 & 725122 & 1913 to present & 361 & 3.49 \\
\hline 01170000 & Deerfield River near West Deerfield & 423209 & 723914 & $\begin{array}{l}1904-1905,1940 \\
\text { to present }\end{array}$ & 557 & -- \\
\hline
\end{tabular}




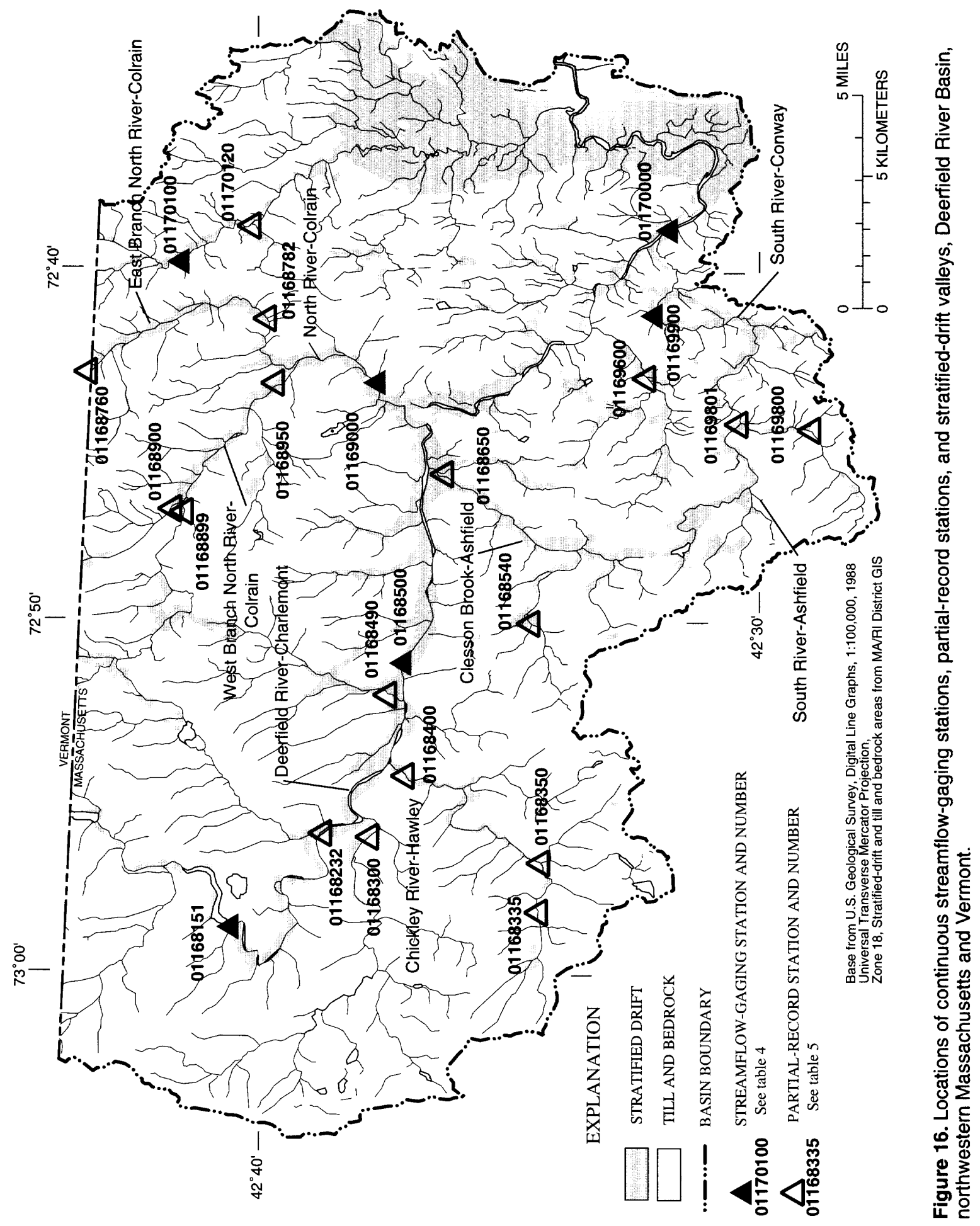




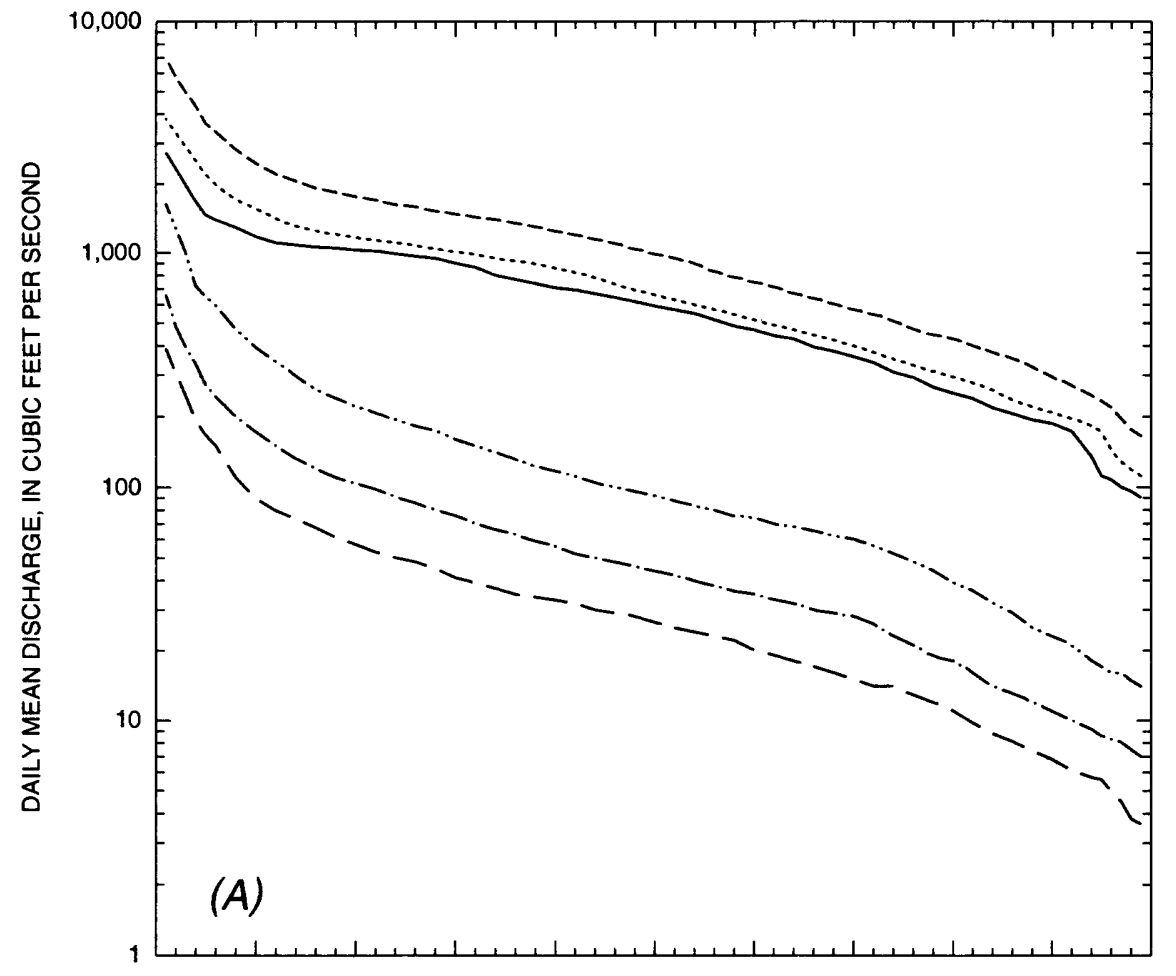

\section{EXPLANATION}

GAGING STATIONS ON REGULATED DEERFIELD RIVER

Deerfield River near West Deerfield (01170000)

Deerfield River at Charlemont (01168500)

Deerfield River

near Rowe (01168151)

GAGING STATIONS ON UNREGULATED TRIBUTARIES

North River

at Shattuckville (01169000) near Colrain (01170100)

-- South River near Conway (01169900)

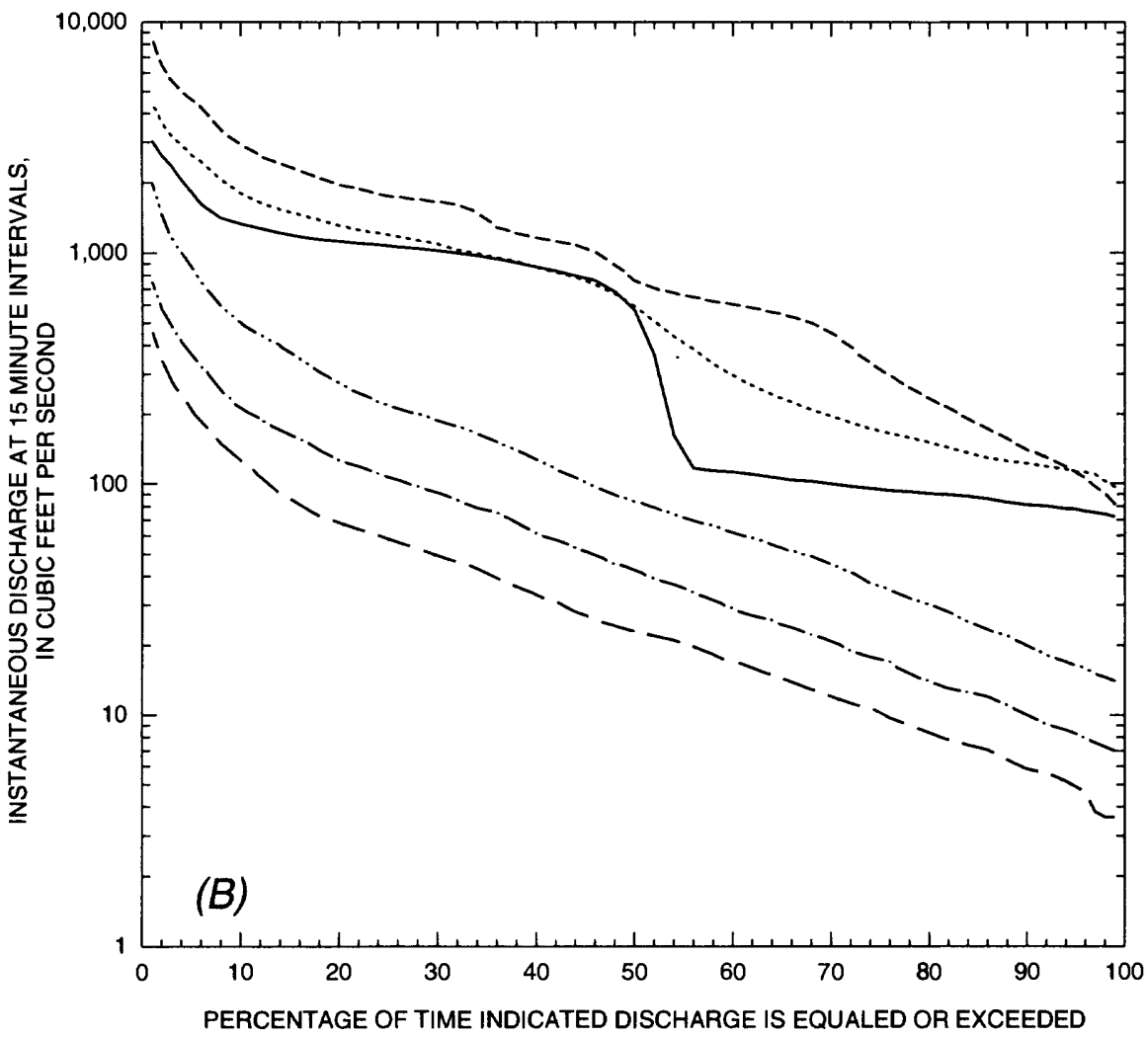

Figure 17. Flow-duration curves based on $(A)$ daily mean discharges and $(B)$ instantaneous discharges at six streamflowgaging stations in the Deerfield River Basin, northwestern Massachusetts, water years 1992-94. 
Flow-duration curves also were constructed using instantaneous discharges collected at 15-minute intervals. The same 3-year period of record was used as for the daily mean discharges, but instantaneous discharges were not used on days when streamflows at any of the gaging stations were affected by ice and on days with no record. Instantaneous discharges were used only on days when the record was available for all six gaging stations; therefore, the flow-duration curves for all six gaging stations are based on common days of record during the 3-year period.

The shape of the flow-duration curves constructed from instantaneous discharge data from the regulated stations on the Deerfield River differ from those for stations on the unregulated tributaries (fig. 17B). The high-flow and the low-flow ends of the flow-duration curves for Deerfield River near Rowe (01168151) and Deerfield River at Charlemont $(01168500)$ are flatter than those for the unregulated stations, with a sharp bend in the middle part of the flow-duration curve. The two flat sections of the curves represent the high storage releases and the intervening low storage releases. The flow-duration curve for Deerfield River near Rowe (01168151) has a sharper bend in the middle than the curve for the Deerfield River at Charlemont (01168500). The sharp bend in the flow-duration curve probably is due to the fact that the Deerfield River near Rowe (01168151) is only $600 \mathrm{ft}$ downstream from a dam so that channel and riverbank storage drain out of the river more quickly than at the Deerfield River at Charlemont (01168500). The Deerfield River at Charlemont (01168500) is several miles downstream from the dam and at the downstream end of stratified-drift valley. The flow-duration curve at the Deerfield River near West Deerfield (01170000) has three flat sections and corresponding bends in the curve, but these features are not as distinctive as those for the other two regulated stations. The Deerfield River near West Deerfield (01170000) is separated from the Deerfield River near Rowe (01168151) and the Deerfield River at Charlemont $(01168500)$ by four dams whose regulation affects streamflow differently than the dams upstream from the other two regulated gaging stations.

\section{Streamflow at Times of Low Flow}

Balancing the water needs of competing users with the in-stream flow needs of fish and wildlife requires estimates of the magnitude and duration of streamflow at times of low flow. During periods of low flow, multiple demands may approach or exceed available streamflow. Streamflow during low-flow periods consists mostly or entirely of ground-water discharge.

Streamflows at selected durations were determined for several stations in the Deerfield River Basin at the downstream end of drainage areas that include stratified-drift valleys; streamflow per unit area from stratified drift covered areas usually exceeds that from equal areas of till and bedrock during periods of low flow. Water available for recharge to ground water in a stratified-drift valley exceeds water available from upland till and bedrock because water is available not only from direct infiltration of precipitation, but also from upland sources (discussed in the recharge section of this report). In addition, because infiltration and storage capacities of stratified drift exceed those for till and bedrock, more ground water is available to discharge to streams from stratified drift during lowflow periods than from till and bedrock.

Some stations also were selected because they drain areas of mostly till and bedrock. Streamflows at the selected durations are compared for drainage areas with various percentages of stratified drift in a subsequent section of this report to provide insights about basin characteristics that affect streamflow during low-flow periods.

\section{Streamflow at Gaging Stations and Partial-Record Stations}

Streamflows exceeded between 80 - and 99percent of the time were calculated for the 3 continuous streamflow-gaging stations and 16 partial-record stations on the unregulated tributaries to the Deerfield River to indicate magnitude of streamflow during low-flow periods. Descriptions of stations on the unregulated tributaries for which flow-duration values are calculated are listed in tables 4 and 5 and the locations of the stations are shown in figure 16. 
Table 5. Description of partial-record stations, Deerfield River Basin, northwestern Massachusetts and Vermont

[USGS station No.: Locations shown in figure 16. Latitude and longitude are given in degrees, minutes, seconds. Stratified-drift areas were measured by geographic information systems technology. USGS, U.S. Geological Survey; $\mathrm{mi}^{2}$, square mile]

\begin{tabular}{|c|c|c|c|c|c|}
\hline $\begin{array}{c}\text { USGS } \\
\text { station No. }\end{array}$ & Station name & $\begin{array}{c}\text { Latitude } \\
\circ, " \prime\end{array}$ & $\begin{array}{c}\text { Longtitude } \\
\text { L." }\end{array}$ & $\begin{array}{c}\text { Drainage } \\
\text { area } \\
\left(\mathbf{m i}^{2}\right)\end{array}$ & $\begin{array}{l}\text { Stratified- } \\
\text { drift area } \\
\text { (percent) }\end{array}$ \\
\hline \multicolumn{6}{|c|}{ Partial-Record Stations on Unregulated Tributaries to Deerfield River } \\
\hline 01168300 & Cold River near Zoar, Mass. & 423812 & 725610 & 29.6 & 0.68 \\
\hline 01168335 & Chickley River near West Hawley, Mass. & 423445 & 725807 & 5.87 & 1.87 \\
\hline 01168350 & King Brook at West Hawley, Mass. & 423440 & 725648 & 5.24 & .57 \\
\hline 01168490 & Mill Brook at Charlemont, Mass. & 423754 & 725209 & 11.9 & 6.81 \\
\hline 01168540 & Clesson Brook near Buckland Four Corners, Mass. & 423500 & 725012 & 4.51 & .66 \\
\hline 01168650 & Clesson Brook near Shelburne Falls, Mass. & 423647 & 724610 & 18.2 & 11.9 \\
\hline 01168760 & East Branch North River near Halifax, Vt. & 424422 & 724340 & 39.6 & 2.45 \\
\hline 01168782 & East Branch North River below tributary at Colrain, Mass. & 424026 & 724155 & 49.1 & 4.56 \\
\hline 01169800 & Poland Brook near Conway, Mass. & 422916 & 724447 & 4.02 & 2.24 \\
\hline 01169801 & South River near Burkville, Mass. & 424315 & 724437 & 15.6 & 12.3 \\
\hline 01170120 & Stafford Brook near Colrain, Mass. & 424047 & 723915 & 2.38 & 2.10 \\
\hline
\end{tabular}

Partial-Record Station on Regulated Deerfield River

01168232 Deerfield River at Zoar, Mass.

$422908 \quad 725601$

276.2

3.10

Streamflows at the selected durations were calculated for the three gaging stations using daily mean discharges and a common base period of 26 climatic years, April 1, 1968 to March 31,1994². Data from these gaging stations also were used to determine streamflows during the base period at the corresponding durations at the partial-record stations. The drainage areas for the gaging stations have similar geology, topography, and precipitation, and are in proximity to the partial-record stations.

Streamflow measurements made at the partialrecord stations were related to concurrent daily mean discharges at each of the three gaging stations. These

\footnotetext{
${ }^{2} \mathrm{~A}$ climatic year is the 12-month period beginning April 1 and ending March 31 . It is designated by the calender year in which it begins.
}

relations were used to estimate flow-duration values for the partial-record stations that reflect conditions during the 26-year base period. Two different methods of relation were used to estimate flow-duration values for the partial-record stations (1) Maintenance of Variance Extension, Type 1, (MOVE.1), which was developed by Hirsch (1982); and (2) graphical-correlation technique, which is described by Searcy (1959). Three to six measurements were made at baseflow conditions each year for 2 years at each partial-record station, and, along with available historical measurements, were related to concurrent daily mean discharges at each of the three continuous gaging stations. Plots of log-transformed data indicated whether the relation was linear or curved. If the plots showed a linear relation, then the MOVE. 1 technique was used to determine flow-duration values for the partial-record station; if the plots indicated curvature, then the graphical-correlation technique was used. 
For each partial-record station, the method of analysis (MOVE.1 or graphical), the streamflowgaging station or stations, and the number of streamflow measurements used to estimate the streamflows at the selected durations are summarized in table 6. Streamflow measurements made at the partial-record stations during this study are reported in the U.S. Geological Survey water-resource data

Table 6. Summary of the method of analysis, streamflowgaging station(s), and number of measurements used to calculate streamflows and the root mean square error of estimate for each partial-record station, Deerfield River Basin, northwestern Massachusetts and Vermont, climatic years 1968-93

[USGS Station No.: Locations shown in figure 16. USGS, U.S. Geological Survey]

\begin{tabular}{|c|c|c|c|c|}
\hline $\begin{array}{c}\text { USGS } \\
\text { Station No. }\end{array}$ & $\begin{array}{l}\text { Method of } \\
\text { analysis }\end{array}$ & $\begin{array}{l}\text { Streamflow- } \\
\text { gaging } \\
\text { station(s) } \\
\text { used in } \\
\text { relation }\end{array}$ & $\begin{array}{c}\text { Number } \\
\text { of } \\
\text { measure- } \\
\text { ments } \\
\text { used in } \\
\text { relation }\end{array}$ & $\begin{array}{c}\text { Root mean } \\
\text { square } \\
\text { error } \\
\text { of estimate } \\
\text { (percent) }\end{array}$ \\
\hline 01168300 & MOVE.1 & $\begin{array}{l}\text { North River } \\
\text { Green River }\end{array}$ & $\begin{array}{l}30 \\
28\end{array}$ & $\begin{array}{l}32.8 \\
30.9\end{array}$ \\
\hline 01168335 & MOVE.1 & Green River & 9 & 20.7 \\
\hline 01168350 & MOVE.1 & $\begin{array}{l}\text { North River } \\
\text { Green River }\end{array}$ & $\begin{array}{l}15 \\
14\end{array}$ & $\begin{array}{l}27.2 \\
25.2\end{array}$ \\
\hline 01168400 & MOVE.1 & $\begin{array}{l}\text { North River } \\
\text { Green River }\end{array}$ & $\begin{array}{l}23 \\
23\end{array}$ & $\begin{array}{l}27.8 \\
28.6\end{array}$ \\
\hline 01168490 & MOVE.1 & $\begin{array}{l}\text { South River } \\
\text { Green River }\end{array}$ & $\begin{array}{l}7 \\
7\end{array}$ & $\begin{array}{l}14.5 \\
14.0\end{array}$ \\
\hline 01168540 & MOVE.1 & Green River & 10 & 31.4 \\
\hline 01168650 & MOVE.1 & $\begin{array}{l}\text { South River } \\
\text { Green River }\end{array}$ & $\begin{array}{l}24 \\
24\end{array}$ & $\begin{array}{l}33.1 \\
33.3\end{array}$ \\
\hline 01168760 & Graphical & $\begin{array}{l}\text { North River } \\
\text { Green River }\end{array}$ & $\begin{array}{l}10 \\
10\end{array}$ & $\begin{array}{l}14.1 \\
17.6\end{array}$ \\
\hline 01168782 & MOVE.1 & $\begin{array}{l}\text { North River } \\
\text { Green River }\end{array}$ & $\begin{array}{l}10 \\
10\end{array}$ & $\begin{array}{l}3.50 \\
7.12\end{array}$ \\
\hline 01168899 & Graphical & $\begin{array}{l}\text { North River } \\
\text { Green River }\end{array}$ & $\begin{array}{l}10 \\
10\end{array}$ & $\begin{array}{c}10.5 \\
9.90\end{array}$ \\
\hline 01168900 & MOVE.1 & Green River & 17 & 22.3 \\
\hline 01168950 & MOVE.1 & $\begin{array}{l}\text { North River } \\
\text { Green River }\end{array}$ & $\begin{array}{l}18 \\
17\end{array}$ & $\begin{array}{l}12.4 \\
14.4\end{array}$ \\
\hline 01169600 & MOVE.1 & $\begin{array}{l}\text { North River } \\
\text { Green River }\end{array}$ & $\begin{array}{l}14 \\
13\end{array}$ & $\begin{array}{l}24.2 \\
25.7\end{array}$ \\
\hline 01169800 & Graphical & South River & 16 & 36.9 \\
\hline 01169801 & Graphical & South River & 11 & 5.04 \\
\hline 01170120 & Graphical & $\begin{array}{l}\text { North River } \\
\text { Green River }\end{array}$ & $\begin{array}{l}9 \\
9\end{array}$ & $\begin{array}{l}11.4 \\
11.4\end{array}$ \\
\hline
\end{tabular}

reports for Massachusetts (Gadoury and others, 1994, 1995; Socolow and others, 1996). Streamflow measurements from the continuous gaging station that had the best relation with the streamflow measurements made at the partial-record station was usually used to determine the flow-duration values; however, if flow from two gaging stations had similar relations, then both were used to calculate the flowduration values. The two sets of values were then averaged to determine the final values for the partialrecord station. Also included in table 6 is the root mean square error of estimate of the relation between the partial-record station and the continuous gaging station. The root mean square error is a measure of the variance about the line or curve of relation. Flowduration values are estimated with greater confidence from relations with lower mean root square errors than from relations with higher root mean square errors.

At Stafford Brook near Colrain (01170120), six historical streamflow measurements made from 1967 to 1969 were available for use in computing the final long-term flow-duration values for the station. However, the relations between the historical flows at Stafford Brook and concurrent flows at the continuous gaging stations were different than those for the data collected during this study. The historical streamflows generally were larger than those indicated by current measurements; therefore, the historical streamflows were not used in developing the relations. The flowduration values calculated using measurements made during this study probably are more indicative of future streamflows than calculated streamflows using historical and current measurements. The difference between the historical and current measurements may be due to land-use changes that have reduced streamflow during low-flow periods; other partialrecord stations with historical data did not show this trend.

Streamflows between 80- and 99-percent durations, determined for the base period at each of the continuous streamflow-gaging stations and partial-record stations, are listed in table 7. Streamflows for these durations are presented because streamflow measurements made at the 
Table 7. Streamflow at selected durations for streamflow-gaging stations and partial-record stations on unregulated tributaries, Deerfield River Basin, northwestern Massachusetts and Vermont, climatic years 1968-93

[USGS station No.: Locations shown in figure 16. USGS, U.S. Geological Survey]

\begin{tabular}{|c|c|c|c|c|c|c|c|c|c|}
\hline \multirow{2}{*}{$\begin{array}{c}\text { USGS } \\
\text { station } \\
\text { No. }\end{array}$} & \multirow{2}{*}{ Station name } & \multicolumn{8}{|c|}{$\begin{array}{l}\text { Streamflow equaled or exceeded at indicated percentage of time, } \\
\text { in cubic feet per second }\end{array}$} \\
\hline & & 80 & 85 & 90 & 93 & 95 & 97 & 98 & 99 \\
\hline \multicolumn{10}{|c|}{ Streamflow-Gaging Stations } \\
\hline 01169000 & North River at Shattuckville, Mass. & 39 & 32 & 25.2 & 21.1 & 19 & 17 & 16 & 13 \\
\hline 01169900 & South River near Conway, Mass. & 11 & 9.2 & 7.5 & 6.5 & 5.8 & 5.0 & 4.5 & 3.8 \\
\hline 01168300 & Cold River near Zoar, Mass. & 8.66 & 6.89 & 5.22 & 4.20 & 3.71 & 3.21 & 2.96 & 2.38 \\
\hline 01168335 & Chickley River near West Hawley, Mass. & 2.55 & 2.13 & 1.70 & 1.42 & 1.28 & 1.12 & 1.04 & .89 \\
\hline 01168350 & King Brook at West Hawley, Mass. & 1.84 & 1.49 & 1.16 & .95 & .85 & .75 & .69 & .57 \\
\hline 01168400 & Chickley River near Charlemont, Mass. & 10.6 & 8.88 & 7.14 & 6.02 & 5.46 & 4.88 & 4.58 & 3.87 \\
\hline 01168760 & East Branch North River near Halifax, Vt. & 11.7 & 10.1 & 7.75 & 5.92 & 5.24 & 4.63 & 4.34 & 3.74 \\
\hline 01168782 & $\begin{array}{l}\text { East Branch North River below tributary at } \\
\text { Colrain, Mass. }\end{array}$ & 18.2 & 14.6 & 11.3 & 9.19 & 8.17 & 7.13 & 6.59 & 5.38 \\
\hline 01168899 & West Branch North River near North Heath, Mass. & 6.24 & 4.64 & 3.17 & 2.36 & 1.98 & 1.66 & 1.50 & 1.22 \\
\hline 01168900 & Sanders Brook near North Heath, Mass. & 1.44 & 1.27 & 1.10 & .97 & .90 & .83 & .78 & .71 \\
\hline 01168950 & West Branch North River at Lyonsville, Mass. & 12.5 & 10.3 & 8.22 & 6.89 & 6.22 & 5.53 & 5.18 & 4.34 \\
\hline 01169600 & Bear River near Conway, Mass. & 3.37 & 2.68 & 2.05 & 1.66 & 1.47 & 1.29 & 1.19 & .97 \\
\hline 01169800 & Poland Brook near Conway, Mass. & 1.42 & 1.08 & .77 & .60 & .49 & .37 & .31 & .23 \\
\hline 01169801 & South River near Burkville, Mass. & 6.80 & 5.64 & 4.58 & 3.98 & 3.59 & 3.17 & 2.92 & 2.59 \\
\hline 01170120 & Stafford Brook near Colrain, Mass. & .39 & .35 & .28 & .20 & .16 & .14 & .12 & .10 \\
\hline
\end{tabular}

partial-record stations are within this range.

Streamflows presented for the stations may underestimate total flow from the basin if groundwater underflow exists at the measuring station. At most locations, measuring stations were selected where little or no underflow could occur; therefore, most or all ground water upstream from the station discharged to the stream and was measured at the station. The station on Clesson Brook near Shelburne Falls (01168650), however, drains a basin that widens at the downstream end and is underlain by stratified drift; therefore, total flows from the basin are likely underestimated. The rate of underflow is a function of the area of saturated material perpendicular to groundwater flow, the hydraulic conductivity of the material, and the hydraulic gradient.
Flow-duration values determined for the North River gaging station also underestimate total flow from the basin because water is transferred out of this drainage area from upstream of the gaging station to supply the needs for a municipality. However, the water transferred is a small percentage of the natural streamflow even at the lowest flows. Water transferred from the subbasin during 1986 averaged $0.36 \mathrm{ft}^{3} / \mathrm{s}$ (Bratton, 1991).

\section{Streamflow from Stratified-Drift Valleys}

Surface-water inflow from upstream of some of the stratified-drift valleys was subtracted from the downstream basin surface outflow to determine streamflow originating from the individual 
stratified-drift valleys. By subtracting-out surfacewater inflow upstream of the valley, variations in ground-water discharge from the individual stratifieddrift valleys could be determined. The stratified-drift valleys were designated by the river draining the valley and the town in which most of the drainage area lies. Basin characteristics of the valleys for which streamflows are determined are shown in table 8 and their locations are shown in figure 16. Although the drainage areas contain major deposits of stratified drift, they also contain areas of till and bedrock that are not

Table 8. Description of stratified-drift valleys, Deerfield River Basin, northwestern Massachusetts

[Stratified-drift valleys: Locations shown in figure $16 . \mathrm{mi}^{2}$, square mile]

\begin{tabular}{|c|c|c|}
\hline Stratified-drift valleys & $\begin{array}{c}\text { Drainage } \\
\text { area } \\
\left(\mathrm{mi}^{2}\right)\end{array}$ & $\begin{array}{l}\text { Stratified- } \\
\text { drift area } \\
\text { (percent) }\end{array}$ \\
\hline \multicolumn{3}{|c|}{$\begin{array}{l}\text { Stratified-Drift Valleys on Unregulated } \\
\text { Tributaries to Deerfield River }\end{array}$} \\
\hline Chickley River-Hawley.............................. & 16.0 & 5.06 \\
\hline Clesson Brook-Buckland ............................ & 13.7 & 15.6 \\
\hline East Branch North River-Colrain............... & 9.50 & 13.4 \\
\hline West Branch North River-Colrain............. & 12.9 & 8.68 \\
\hline 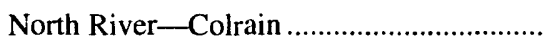 & 10.1 & 9.41 \\
\hline 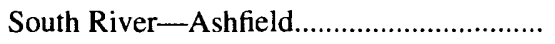 & 11.6 & 15.8 \\
\hline 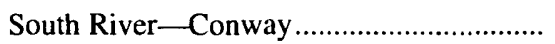 & 8.50 & 14.8 \\
\hline
\end{tabular}

Stratified-Drift Valley on Regulated Deerfield River

\begin{tabular}{llll}
\hline Deerfield River-Charlemont ...................... & 16.2 & 13.0
\end{tabular} drained by large tributaries. Seven stratified-drift valleys are on unregulated tributaries to the Deerfield River and one is on the regulated Deerfield River.

For stratified-drift valleys on the unregulated tributaries, streamflows at the selected durations from stations upstream of the individual stratified-drift valleys were subtracted from streamflows at the stations at the downstream end. For example, the 90-percent duration streamflow at the East Branch North River below tributary at Colrain (01168782) was $11.3 \mathrm{ft}^{3} / \mathrm{s}$, and at the West Branch North River at Lyonsville (01168950) was $8.22 \mathrm{ft}^{3} / \mathrm{s}$. Both stations are at the upstream end of the North River-Colrain stratified-drift valley. The 90 -percent duration streamflows for the upstream stations were subtracted from the value determined at the North River gaging station (01169000), $25.2 \mathrm{ft}^{3} / \mathrm{s}$, which is at the downstream end, to determine the 90 -percent duration streamflow from the North River-Colrain stratified-drift valley, $5.68 \mathrm{ft}^{3} / \mathrm{s}$.

Flow-duration values determined for the stratified-drift valleys on the unregulated tributaries are presented in table 9. As discussed in the previous section, if underflow occurs, total flows from the stratified-drift valleys may be underestimated. Also, the total flow from the valleys could be overestimated if underflow occurs at the upstream sites but not at the downstream site. In addition, flows from the North River-Colrain stratified-drift valley are underestimated

Table 9. Streamflow at selected durations for stratified-drift valleys on unregulated tributaries, Deerfield River Basin, northwestern Massachusetts, climatic years 1968-93

[Stratified-drift valleys: Locations shown in figure 16 and described in table 8]

\begin{tabular}{|c|c|c|c|c|c|c|c|c|}
\hline \multirow[t]{2}{*}{ Stratified-drift valleys } & \multicolumn{8}{|c|}{$\begin{array}{l}\text { Streamflow equaled or exceeded at indicated percentage of time, } \\
\text { in cubic feet per second }\end{array}$} \\
\hline & 80 & 85 & 90 & 93 & 95 & 97 & 98 & 99 \\
\hline Clesson Brook-Buckland ............................ & 5.90 & 5.04 & 4.19 & 3.66 & 3.32 & 2.93 & 2.68 & 2.33 \\
\hline East Branch North River - Colrain ............... & 6.50 & 4.50 & 3.55 & 3.27 & 2.93 & 2.50 & 2.25 & 1.64 \\
\hline West Branch North River-Colrain.............. & 4.82 & 4.39 & 3.95 & 3.56 & 3.34 & 3.04 & 2.90 & 2.41 \\
\hline South River-Ashfield................................... & 5.38 & 4.56 & 3.81 & 3.38 & 3.10 & 2.80 & 2.61 & 2.36 \\
\hline jouth River - Conway ............................... & 4.20 & 3.56 & 2.92 & 2.52 & 2.21 & I.83 & 1.58 & I.2I \\
\hline
\end{tabular}


because of the transfer of water out of the basin. Water transferred out of the basin equals 11 percent of the flow at the 99-percent duration.

Because of flow regulation on the Deerfield River, flow-duration analysis could not be used to determine the natural low flows, and hence ground-water discharge from the Deerfield River-Charlemont stratified-drift valley. Streamflow measurements were made from three major tributaries to the Deerfield River and at the upstream end of the valley to determine the net groundwater contribution from the stratified-drift valley. These streamflows were subtracted from the streamflow at the downstream end of the valley (fig. 16). Streamflows on the Deerfield River were measured near the end of the hydrograph recession during periods of low releases from the upstream dam when storage due to high releases had drained out of the channel and banks. A total of seven sets of seepage measurements were made over 2 years.

Net streamflow from the Deerfield RiverCharlemont stratified-drift valley for the seven sets of measurements ranged from -2.06 to $13.6 \mathrm{ft}^{3} / \mathrm{s}$ and averaged $6.34 \mathrm{ft}^{3} / \mathrm{s}$. The duration corresponding to this average was estimated by averaging the durations of the seven sets of measured streamflow for the three unregulated tributaries. The average net streamflow, $6.34 \mathrm{ft}^{3} / \mathrm{s}$, for the Deerfield River-Charlemont stratifieddrift valley, was exceeded 92 percent of the time, on average.

Some of the variation in the calculated streamflows from the Deerfield River-Charlemont stratified-drift valley could be attributable to the accuracy of the streamflow measurements and to changes in the amount of water stored in the stratified drift. Streamflow from the tributaries was measured on the edge of the stratified drift near the valley and upland contact. Observations of streamflow from Mill Brook indicated that streamflows at the valley wall were sometimes greater than streamflows on the same day at its confluence with the Deerfield River, indicating that water was going into storage in the stratified drift.

\section{Comparison of Streamflows Per Unit of Drainage Area}

Streamflows between the 80- and 99-percent durations were compared for the 3 streamflow-gaging stations, 16 partial-record stations, and 7 individual stratified-drift valleys on the unregulated tributaries to the Deerfield River, which have a wide range in drainage area. Streamflows at the selected durations for each site were divided by the drainage area upstream of the site and the resulting values of streamflow per square mile are shown in table 10. Streamflows per square mile were highest for North River-Colrain stratified-drift valley and lowest at Stafford Brook near Colrain (01170120). If water was not transferred out of the North River-Colrain stratified-drift valley, values of streamflow per square mile would increase by $0.032\left(\mathrm{ft}^{3} / \mathrm{s}\right) / \mathrm{mi}^{2}$. Streamflow derived from the Deerfield River-Charlemont stratified-drift valley on the regulated Deerfield River is not listed in table 10 , but if the average value of $6.34 \mathrm{ft}^{3} / \mathrm{s}$ at the 92 -percent duration is divided by the drainage area of $16.2 \mathrm{mi}^{2}$, the resulting streamflow per unit area, $0.391\left(\mathrm{ft}^{3} / \mathrm{s}\right) / \mathrm{mi}^{2}$, is greater than that for all other sites at the 90 -percent duration except the North River-Colrain stratified-drift valley.

In a previous study in New England, Wandle and Randall (1994) reported that variation in low flow between sites is mostly due to the percentage of stratified drift and water availability in the drainage area. In the high-relief region of New England, which includes northwestern Massachusetts, Wandle and Randall (1994) determined that coarse-grained stratified drift contributes 4 to 8 times more water, per unit area, than till and bedrock. In the Deerfield River Basin, streamflows per square mile at the 80-, 90-, and 99percent duration for each site listed in table 10 were related by linear regression against the corresponding percentage of stratified drift in each drainage area (fig. 18). Coefficient of determination ( $R^{2}$ values) ranged from 0.16 at the 99 -percent duration to 0.22 at the 90 -percent duration. These $R^{2}$ values indicate that only 16 to 22 percent of the variation in the streamflow per square mile can be attributed to variation in percentage of stratified drift. The low $R^{2}$ values probably are due to the small range in percentage of stratified drift, from 0.57 to 15.8 percent, and because the percentage of stratified drift includes coarse- and fine-grained material. Hydraulic properties of the finegrained stratified drift probably are similar to those of till.

Streamflows at the selected durations from the high-relief region of the Deerfield River Basin also were compared to those from the low-relief region of southeastern Massachusetts. At 26 sites in the 
Table 10. Streamflow per square mile at selected durations for streamflow-gaging stations, partial-record stations, and stratified-drift valleys on unregulated tributaries, Deerfield River Basin, northwestern Massachusetts and Vermont, climatic years 1968-93

[Locations shown in figure 16. USGS, U.S. Geological Survey; NA, not applicable]

\begin{tabular}{|c|c|c|c|c|c|c|c|c|c|}
\hline \multirow{2}{*}{$\begin{array}{c}\text { USGS } \\
\text { station } \\
\text { No. }\end{array}$} & \multirow{2}{*}{ Station name or location } & \multicolumn{8}{|c|}{$\begin{array}{l}\text { Streamflow equaled or exceeded at indicated } \\
\text { percentage of time, in cubic feet per second }\end{array}$} \\
\hline & & 80 & 85 & 90 & 93 & 95 & 97 & 98 & 99 \\
\hline 01166900 & North River at Shattuckville, Mass. & 0.438 & 0.360 & 0.283 & 0.237 & 0.213 & 0.191 & 0.180 & 0.146 \\
\hline 01169900 & South River near Conway, Mass. & .456 & .382 & .311 & .270 & .241 & .207 & .187 & .158 \\
\hline
\end{tabular}

\begin{tabular}{|c|c|c|c|c|c|c|c|c|c|}
\hline \multicolumn{10}{|c|}{ Partial-Record Stations } \\
\hline 01168335 & Chickley River near West Hawley, Mass. & .434 & .363 & .290 & .242 & .218 & .191 & .177 & .152 \\
\hline 01168400 & Chickley River near Charlemont, Mass. & .391 & .328 & .263 & .222 & .201 & .180 & .169 & .143 \\
\hline 01168490 & Mill Brook at Charlemont, Mass. & .348 & .327 & .282 & .251 & .233 & .211 & .198 & .177 \\
\hline 01168760 & East Branch North River near Halifax, Vt. & .295 & .255 & .196 & .149 & .132 & .117 & .110 & .094 \\
\hline 01168782 & East Branch North River below tributary at Colrain, Mass. & .371 & .297 & .230 & .187 & .166 & .145 & .134 & .110 \\
\hline 01168899 & West Branch North River near North Heath, Mass. & .484 & .360 & .246 & .183 & .153 & .129 & .116 & .095 \\
\hline 01168900 & Sanders Brook near North Heath, Mass. & .361 & .318 & .276 & .243 & .226 & .208 & .195 & .178 \\
\hline 01168950 & West Branch North River at Lyonsville, Mass. & .419 & .346 & .276 & .231 & .209 & .186 & .174 & .146 \\
\hline 01170120 & Stafford Brook near Colrain, Mass. & .164 & .147 & .118 & .084 & .067 & .059 & .050 & .042 \\
\hline \multicolumn{10}{|c|}{ Stratified-Drift Valleys } \\
\hline NA & Chickley River-Hawley & 0.388 & 0.329 & 0.268 & 0.228 & 0.208 & 0.188 & 0.178 & 0.151 \\
\hline NA & Clesson Brook-Buckland & .431 & .368 & .306 & .267 & .242 & .214 & .196 & .170 \\
\hline NA & East Branch North River-Colrain & 684 & .474 & .374 & .344 & .308 & .263 & .237 & .173 \\
\hline NA & West Branch North River-Colrain & .374 & .340 & .306 & .276 & .259 & .236 & .225 & .187 \\
\hline NA & North River-Colrain & .822 & .703 & .562 & .497 & .456 & .430 & .419 & .325 \\
\hline NA & South River-Ashfield & .464 & .393 & .328 & .291 & .267 & .241 & .225 & .203 \\
\hline NA & South River-Conway & .494 & .419 & .344 & .296 & .260 & .215 & .186 & .142 \\
\hline
\end{tabular}

Deerfield River Basin, the area of the drainage basin above the sites covered by stratified drift averaged 6.99 percent. Streamflows at the $80-, 90-$, and $99-$ percent durations averaged $0.422,0.280$, and $0.147\left(\mathrm{ft}^{3} / \mathrm{s}\right) \mathrm{mi}^{2}$, respectively. Seven sites in southeastern Massachusetts averaged 11.2 percent stratified drift and streamflows at the 80-, 90-, and 99percent duration averaged $0.261,0.113$, and $0.0236\left(\mathrm{ft}^{3} / \mathrm{s}\right) / \mathrm{mi}^{2}$, respectively, (Bent, 1995).
Streamflows at the selected durations at sites in the Deerfield River Basin exceeded those at sites in southeastern Massachusetts most likely because the average annual runoff (equivalent to precipitation minus evapotranspiration) from the high-relief region of the Deerfield River Basin exceeds that from the lowrelief region of southeastern Massachusetts by about 3 in. (depth of water over a drainage basin) (Knox and Nordenson, 1955). 

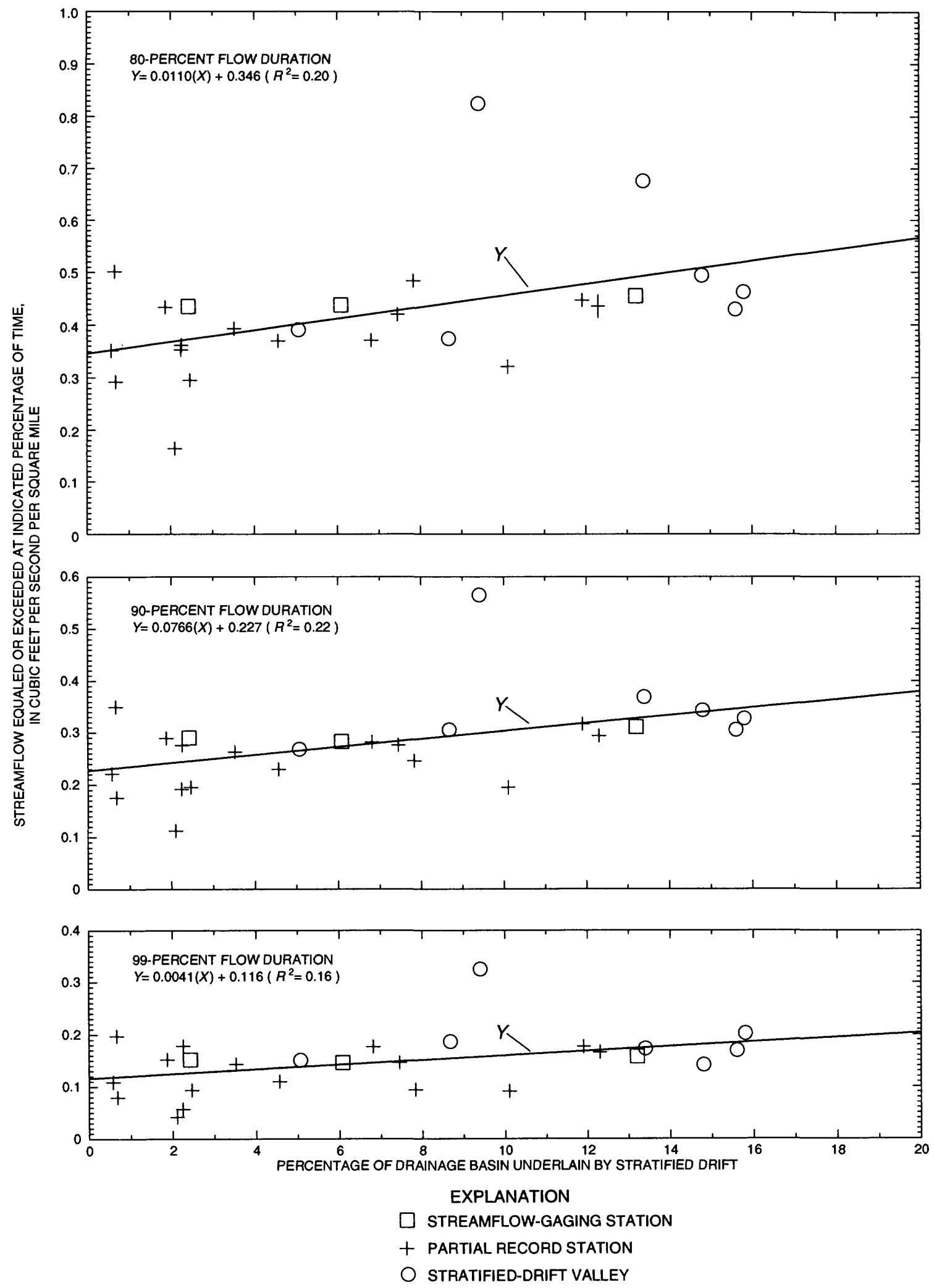

Figure 18. Streamflow per square mile equaled or exceeded 80,90 , and 99 percent of the time in relation to percentage of basin underlain by stratified drift in the Deerfield River Basin, northwestern Massachusetts and Vermont, climatic years 1968-93. 


\section{SUMMARY AND CONCLUSIONS}

The Deerfield River drains $347 \mathrm{mi}^{2}$ of northwestern Massachusetts and encompasses all or a part of 20 towns. Strict Federal drinking-water standards have increased interest in ground water as a source for public-water supply. Coarse-grained stratified drift provides the most favorable material for public-water supplies in the basin. Stratified drift was deposited by glacial meltwater in the narrow river valleys of the Berkshire Hills and in the broad valley of the Connecticut Valley Lowlands. An increased understanding of the geohydrology of stratified drift is needed to plan the optimal use of ground-water resources and the development of new drinking-water supplies. In addition, because of multiple uses of surface water in the basin, hydrologic information is needed to aid water planners in maintaining adequate in-stream water.

A map of lines of equal thickness of stratified drift in the Connecticut Valley Lowlands was prepared based on seismic-refraction and seismic-reflection surveys completed for this study and from historical hydrologic data. The line of equal thickness map indicates a deeper north-south trending buried valley than a map prepared in the 1970's; the north-south trending valley features an area of glacial overdeepening. Maximum thickness of the stratified drift is $385 \mathrm{ft}$. Results of a seismic-reflection survey indicate fine-grained stratified drift may be underlain by coarse-grained stratified drift ranging in thickness from 0 to $150 \mathrm{ft}$. A lithologic log verifies that the coarse-grained deposits underlie the fine-grained deposits in one location. No municipality currently uses these buried coarse-grained deposits as a source of ground-water supply.

Surface-water fluctuations on the mainstem of the Deerfield River due to dam regulation cause ground-water levels to fluctuate in the adjacent stratified drift. A cross-sectional ground-water-flow model was used to simulate the response of ground-water fluctuations to stage changes in the river to estimate hydraulic properties of the stratified drift and to improve the understanding of the hydrology of the stream-aquifer system. A comparison of measured and simulated heads resulted in hydrologic properties of $3 \mathrm{ft} / \mathrm{d}$ for vertical riverbed hydraulic conductivity, 40:1 anisotropic ratio of horizontal to vertical hydraulic conductivity, and 0.040 and 0.0002 for unconfined and confined storage, respectively. The horizontal hydraulic conductivity was estimated from lithologic logs and resulted in a hydraulic diffusivity (transmissivity divided by the unconfined storage) for the site equal to $168,000 \mathrm{ft}^{2} / \mathrm{d}$. Varying the vertical hydraulic conductivity of the riverbed caused the greatest effect on heads near the river, whereas varying the anisotropic ratio of the horizontal to vertical hydraulic conductivity caused the greatest effects on heads in the deep part of the stratified drift. Varying the storage of the unconfined layer caused a substantial effect on all heads, especially heads farthest from the river, whereas varying the storage for the confined layers caused little change in heads.

Recharge and its seasonal variability was determined for a stratified-drift valley that is bordered by upland till and bedrock. A ground-water-flow model was used to refine concepts of recharge processes by assessing the effect of water available for recharge estimates and resulting simulated heads to measured ground-water levels. Water is available from three different sources: (1) direct infiltration of precipitation on the $0.12 \mathrm{mi}^{2}$ of stratified drift, (2) tributary loss from an upland brook (drainage area $0.07 \mathrm{mi}^{2}$ ) as it crosses the valley, and (3) ground-water and surface-water runoff from $0.21 \mathrm{mi}^{2}$ of uplands. On an annual basis from October 1993 to September 1994, 30 percent of the water available for recharge was from direct infiltration, 7 percent from tributary loss, and 63 percent from ground-water and surface-water runoff; a total of 70 percent of total recharge was available from upland sources. Most of the water available to recharge the stratified-drift valley occurred during late autumn and during the spring snowmelt.

Seasonal variation in recharge not only caused ground-water levels to fluctuate but also caused ground-water flow to change directions. In early spring, the direction of flow is nearly perpendicular to the valley axis whereas in late summer, flow is nearly downvalley. The change in ground-water flow direction may have implications for water-quality studies concerning movement of solutes.

Field observations and the results of simulations made using the ground-water-flow model indicate water available for recharge is greater than actual recharge during the spring snowmelt and during intense precipitation events. By decreasing the estimates of water available for recharge by 10 percent in March and 60 percent in April, the actual recharge to the valley on an annual basis from October 1993 to September 1994 was 20 percent less than original estimates. By reducing the estimates of water available 
for recharge in March and April, simulated and measured heads compared reasonably, but to accurately simulate flow in the valley, a more complex simulation is needed. Estimates of water available for recharge are useful for estimating actual recharge when the water table is below the land surface; however, the water table may, at times, rise to the land surface, thereby limiting recharge in narrow stratified-drift valleys consisting of predominately fine-grained stratified drift and bounded by a large contributing upland area.

Flow-duration curves for three continuous gaging stations on the regulated Deerfield River were compared to those for three continuous gaging stations on geologically similar unregulated tributaries to determine the effects of dam regulation on streamflows. Flow-duration curves were constructed from the daily mean discharge values and from instantaneous discharge values for water years 1992-94 for each of the six continuous gaging stations. The flow-duration curves constructed from the daily mean discharge values for the regulated gaging stations on the Deerfield River were similar to those for the unregulated tributaries because the average of the high and low releases from the dams are usually nearly equivalent on a daily basis to the natural daily mean discharges. However, flow-duration curves constructed from the instantaneous discharge values for the regulated gaging stations were different from those for the unregulated gaging stations; the curves for the regulated gaging stations have distinctive features that reflect the effect of storage releases from the dams.

During periods of low flow, streamflow is predominately ground-water discharge. Streamflows during periods of low flow were determined for 27 sites that have drainage basins in which stratified-drift cover ranges from 0.57 to 15.8 percent of the basin. Streamflows exceeded between 80 and 99 percent of the time for climatic years 1968-93 were determined for the sites on the unregulated tributaries to the Deerfield River. Streamflows per square mile of drainage area were highest from sites at the downstream ends of the North River-Colrain and the Deerfield RiverCharlemont stratified-drift valleys and lowest from Stafford Brook near Colrain. Effects of stratified drift on flow duration were determined by regression analyses of streamflow per square mile at the 80-, 90-, and 99-percent durations against percentage of stratified drift. Because the sites used in the analyses had a small range in percentage of stratified drift and because the percentage of stratified drift includes coarse- and fine-grained deposits, the relations between streamflow per unit area and percentage of area of stratified drift were not highly related. A comparison of streamflows from sites in the Deerfield River Basin to those for sites in southeastern Massachusetts showed that streamflows per square mile in the Deerfield River Basin exceeded those in southeastern Massachusetts. Greater water availability in the Deerfield River Basin than in southeastern Massachusetts probably explains this difference.

\section{REFERENCES CITED}

Almer Huntley, Jr., and Associates, Inc., 1986, Report on hydrogeologic and water quality investigations at Lee Road municipal sanitary landfill, Deerfield, Massachusetts, March 1986: Northampton, Massachusetts, variously paged.

Bear, J., 1979, Hydraulics of groundwater: New York, McGraw-Hill, 569 p.

Bent, G.C., 1995, Streamflow, ground-water recharge and discharge, and characteristics of surficial deposits in Buzzards Bay Basin, southeastern Massachusetts: U.S. Geological Survey Water-Resources Investigations Report 95-4234, 56 p.

Bratton, L., 1991, Public water-supply in Massachusetts, 1986: U.S. Geological Survey Open-File Report 91-86, $108 \mathrm{p}$.

Fenneman, N.M., 1938, Physiography of eastern United States: New York, McGraw-Hill, 714 p.

Ferris, J.G., 1963, Cyclic water-level fluctuations as a basis for determining aquifer transmissibility, in Bentall, R., comps, Methods of determining permeability, transmissibility and drawdown: U.S. Geological Survey Water-Supply Paper 1536-I, p. 305-318.

Franklin County Planning Department, 1990, Deerfield River Comprehensive Management Plan: variously paged.

Freeze, R.A., and Cherry, J.A., 1979, Groundwater: Englewood Cliffs, N.J., Prentice Hall, 604 p.

Gadoury, R.A., Socolow, R.S., Girouard, G.G., and Ramsbey, L.R., 1994, Water resources data for Massachusetts and Rhode Island, water year 1993: U.S. Geological Survey Water-Data Report MA-RI-93-1, $266 \mathrm{p}$. 
Gadoury, R.A., Socolow, R.S., Girouard, G.G., and Ramsbey, L.R., 1995, Water resources data for Massachusetts and Rhode Island, water year 1994: U.S. Geological Survey Water-Data Report MA-RI-94-1, $314 \mathrm{p}$.

Gay, F.B., Toler, L.G., and Hansen, B.P., 1974, Hydrology and water resources of the Deerfield River Basin, Massachusetts: U.S. Geological Survey Hydrologic Investigations Atlas HA-506, 2 sheets.

Haeni, F.P., 1988, Evaluation of the continuous seismicreflection method for determining the thickness and lithology of stratified drift in the glaciated Northeast, in Randall, A.D., and Johnson, A.I., eds., The Northeast glacial aquifers: American Water Resources Association Monograph Series, no. 11, p. 63-82.

Hansen, B.P., Gay, F.B., and Toler, L.G., 1973, Hydrologic data of the Deerfield River Basin, Massachusetts: U.S. Geological Survey Hydrologic-Data Report No. 13, $59 \mathrm{p}$.

Hirsch, R.M., 1982, A comparison of four streamflow record extension techniques: Water Resources Research, v. 18, no. 4., p. 1081-1088.

Jacob, C.E., 1939, Fluctuations in artesian pressure produced by passing railroad-trains as shown in a well on Long Island, New York: American Geophysical Union Transactions of 1939, Part 4, p. 666-674.

Jahns, R.H., 1966, Surficial geologic map of the Greenfield quandrangle, Franklin County, Massachusetts: U.S. Geological Survey Geologic Quandrangle Map GQ-474.

Knox, C.E., and Nordenson T.J., 1955, Average annual runoff and precipitation in the New England-New York area: U.S. Geological Survey Hydrologic Investigations Atlas HA-7, 3 sheets.

Krumbein, W.C., and Monk, G.D., 1943, Permeability as a function of the size parameters of unconsolidated sand: Transactions of the American Institute of Mining and Metallurgical Engineers, v. 151,p. 153-163.

Londquist, C.J., 1975, Depth to bedrock, Greenfield Quandrangle, Massachusetts: U.S. Geological Survey Map MF-629, 1 sheet.

Lohman, S.W., and others, 1972, Definitions of selected ground-water terms-revisions and conceptual refinements: U.S. Geological Survey Water-Supply Paper 1988, $21 \mathrm{p}$.

Lyford, F.P., and Cohen, A.J., 1988, Estimation of water available for recharge to sand and gravel aquifers in the glaciated northeastern United States, in Randall, A.D., and Johnson, A.I., eds., The Northeast glacial aquifers: American Water Resources Association Monograph Series, no. 11, p. 37-62.
McDonald, M.G., and Harbaugh, A.W., 1988, A modular three-dimensional finite-difference ground-water flow model: U.S. Geological Survey Techniques of WaterResources Investigations, Book 6, Chapter A-1, 586 p.

Morrissey, D.J., Randall, A.D., and Williams, J.H., 1988, Upland runoff as a major source of recharge to stratified drift in the glaciated Northeast, in Randall, A.D., and Johnson, A.I., eds., The Northeast glacial aquifers: American Water Resources Association Monograph Series, no. 11, p. 17-36.

Neuman, S.P., 1972, Theory of flow in unconfined aquifers considering delayed response of the water table: Water Resources Research, v. 8, no. 4, p. 1031-1045. 1981, Delayed drainage in a stream-aquifer system: Journal of the Irrigation and Drainage Division, American Society of Civil Engineers, v. 107, no. IR4, p. 407-410.

Randall, A.D., 1978, Infiltration from tributary streams in the Susquehanna River Basin, New York: U.S. Geological Survey Journal of Research, v. 6, no. 3, p. 285-297.

Searcy, J.K., 1959, Flow-duration curves, manual of hydrology-part 2. low-flow techniques: U.S. Geological Survey Water-Supply Paper 1542-A, p. 1-33.

Scott, J.H., Tibbetts, B.L., and Burdick, R.G., 1972, Computer analysis of seismic-refraction data: U.S. Department of the Interior, Bureau of Mines Report of Investigations RI 7595, $95 \mathrm{p}$.

Socolow, R.S., Comeau, L.Y., Casey, R.G., and Ramsbey, L.R., 1996, Water resources data for Massachusetts and Rhode Island, water year 1995: U.S. Geological Survey Water-Data Report MA-RI-95-1, 314 p.

Tighe and Bond Inc., 1992, Aquifer land acquisition study, Millbrook wellfield, Greenfield, Massachusetts, August 1988, revised August 1992: Westfield, Mass., variously paged.

U.S. Department of Commerce, 1991, 1990 Census of population and housing, summary population and housing characteristics, Massachusetts: Washington, D.C., Bureau of the Census, publication 1990/CPH-1-23, variously paged.

Walk, M., Lembke, L., and Shields, S., 1992, Green River Water Monitoring Report, $25 \mathrm{p}$.

Wandle, S.W., Jr., 1984, Gazetteer of hydrologic characteristics of streams in MassachusettsConnecticut River Basin: U.S. Geological Survey Water-Resources Investigations Report 84-4282, 110 p.

Wandle, S.W., Jr., and Randall, A.D., 1994, Effects of surficial geology, lakes and swamps, and annual water availability on low flows of streams in central New England and their use in low-flow estimation: U.S. Geological Survey Water-Resources Investigations Report 93-4092, 57 p. 
APPENDIX A

- pAGE 47 Follows- 

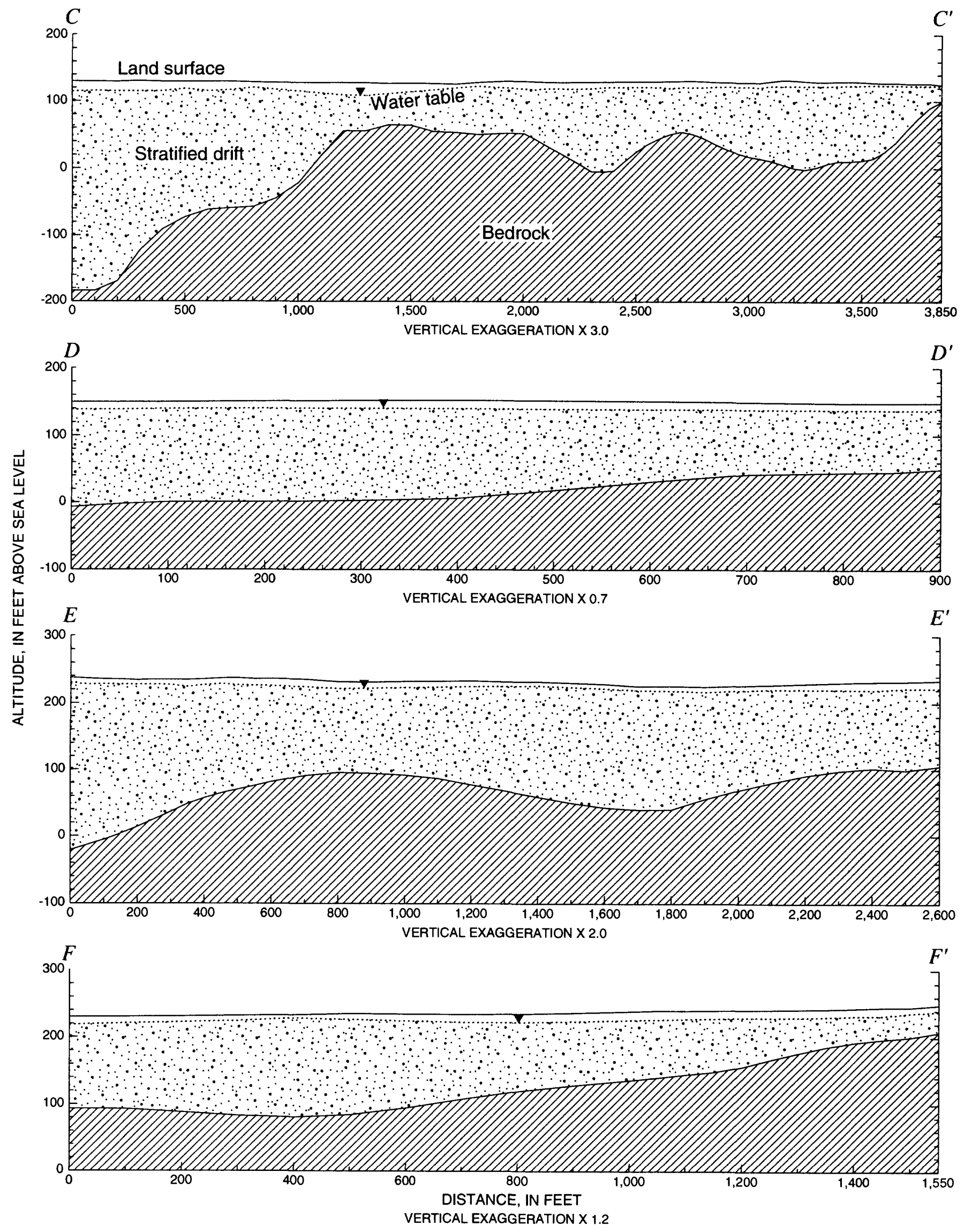

Figure A1. Geohydrologic sections based on seismic-refraction surveys, Deerfield River Basin, northwestern Massachusetts. (Locations of sections shown on plate 1.) 

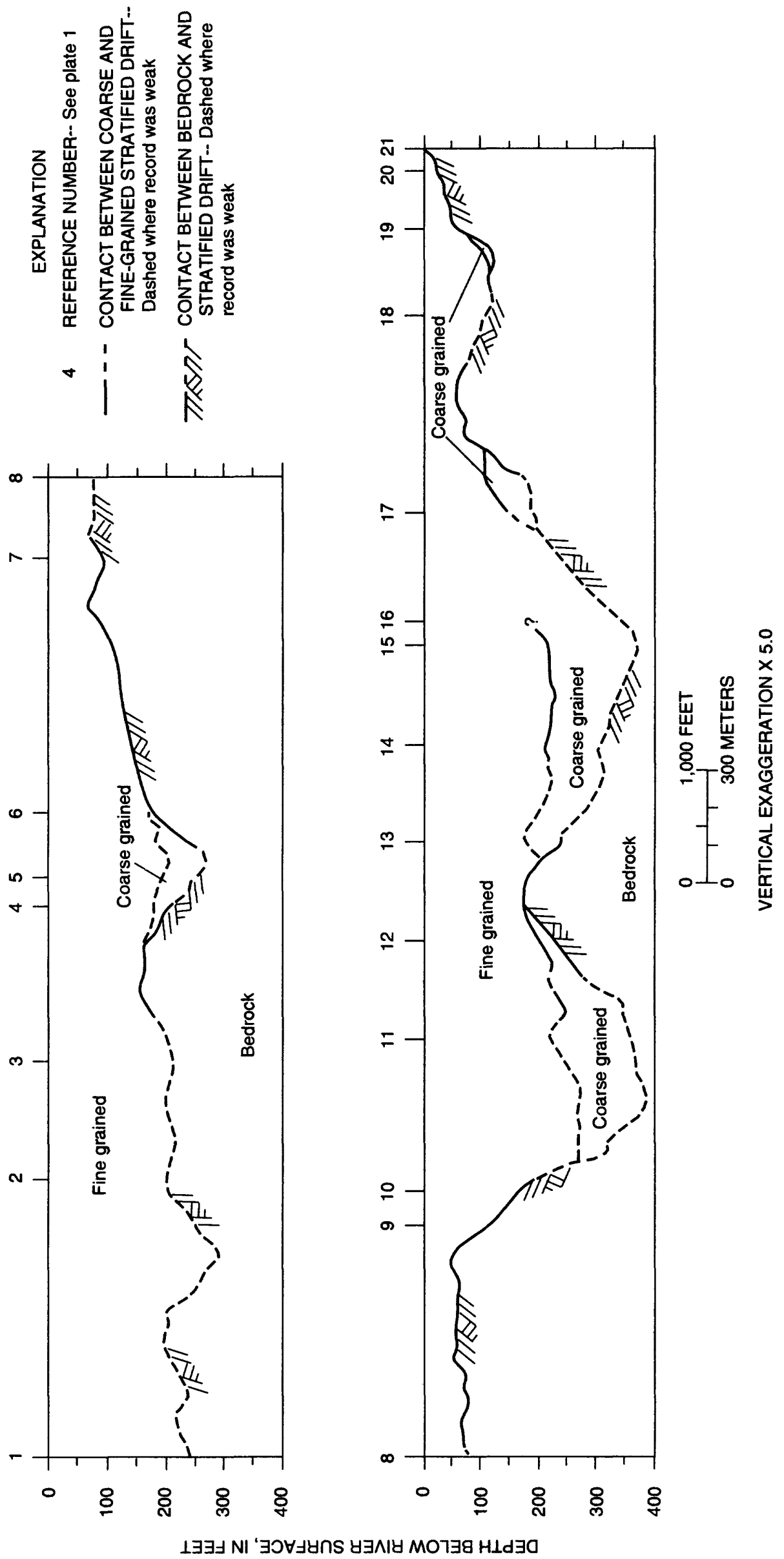

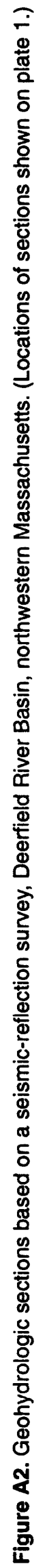




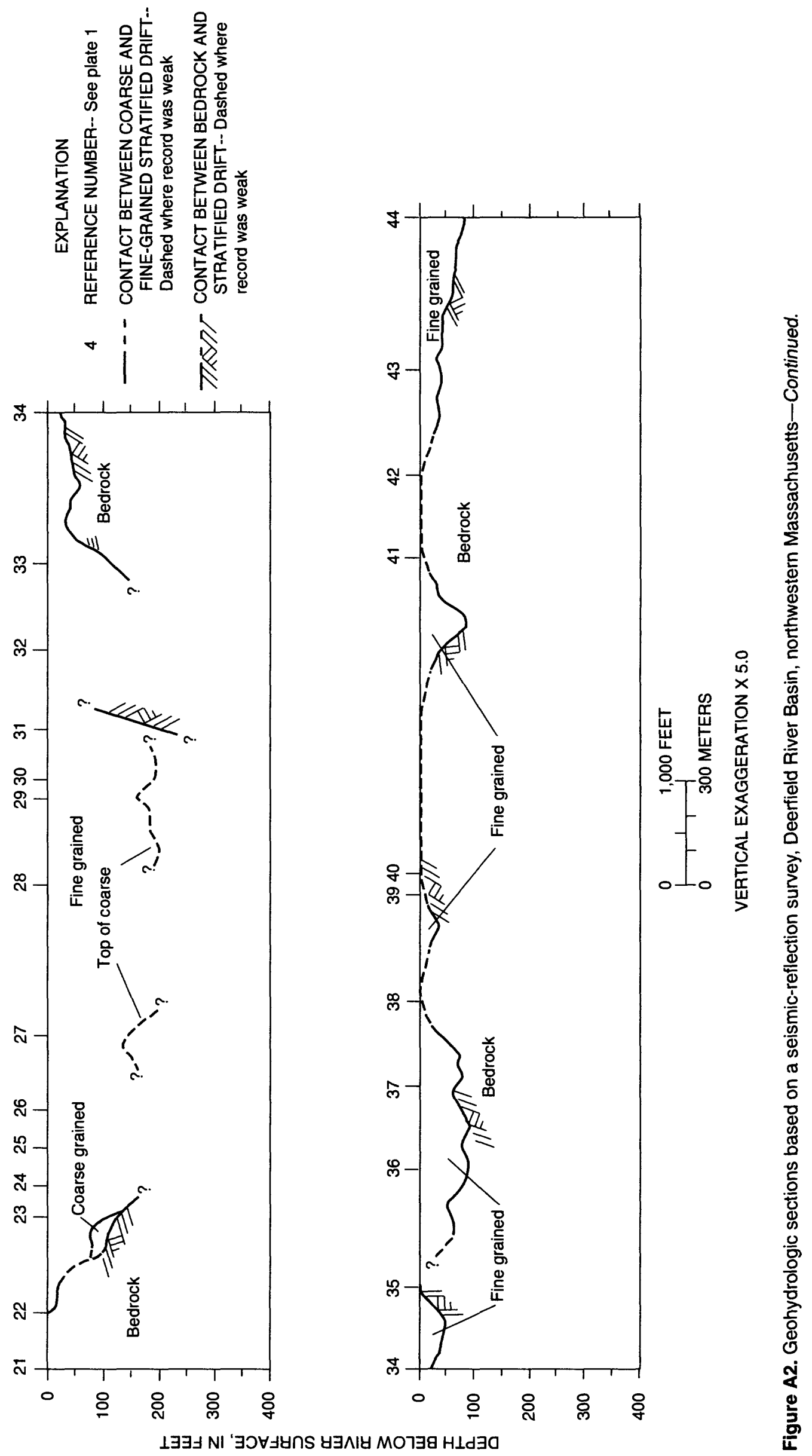

